\title{
FACTORS AFFECTING WATER QUALITY AND NET FLUX OF SOLUTES IN TWO STREAM BASINS IN THE QUABBIN RESERVOIR DRAINAGE BASIN, CENTRAL MASSACHUSETTS, 1983-85
}

\section{BY ROCHELLE L. RITTMASTER and JAMES B. SHANLEY}

U.S. GEOLOGICAL SURVEY

Water-Resources Investigations Report 94-4003

Prepared in cooperation with the

METROPOLITAN DISTRICT COMMISSION and the

MASSACHUSETTS DEPARTMENT OF ENVIRONMENTAL PROTECTION

DIVISION OF WATER POLLUTION CONTROL

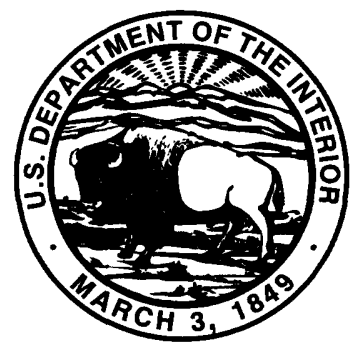

Marlborough, Massachusetts 


\title{
U.S. DEPARTMENT OF THE INTERIOR BRUCE BABBIT, Secretary
}

\author{
U.S. GEOLOGICAL SURVEY \\ Gordon P. Eaton, Director
}

For additional information write to:

Copies of this report can be purchased from:

Chief, Massachusetts-Rhode Island District U.S. Geological Survey Water Resources Division 28 Lord Road, Suite 280 Marlborough, MA 01752
U.S. Geological Survey Earth Science Information Center Open-File Reports Section Box 25286, MS 517

Federal Center

Denver, CO 80225 


\section{CONTENTS}

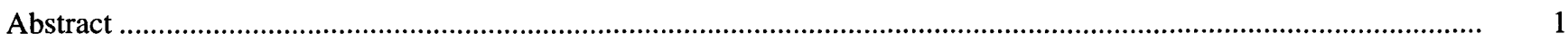

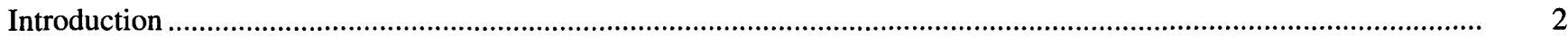

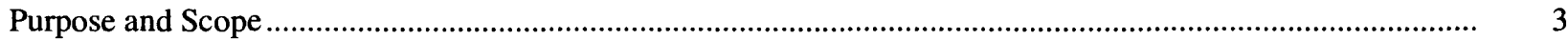

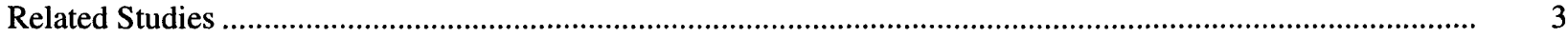

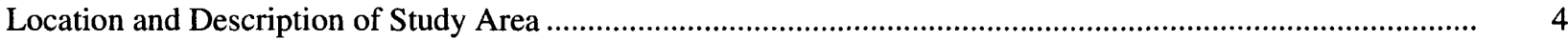

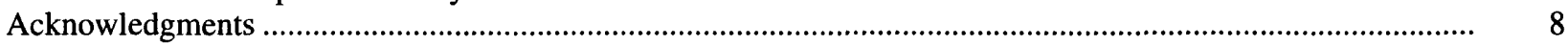

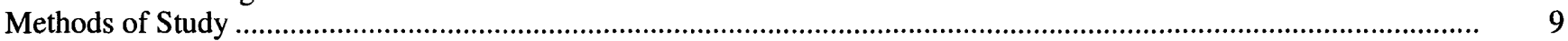

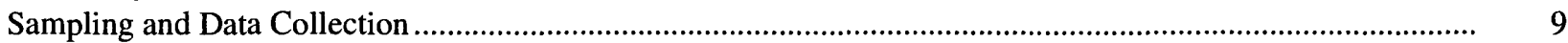

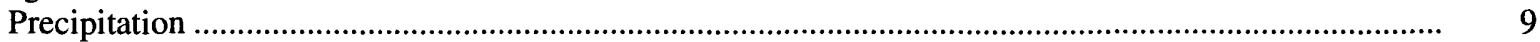

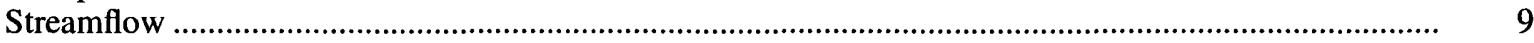

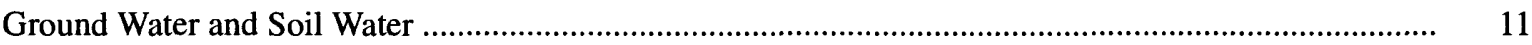

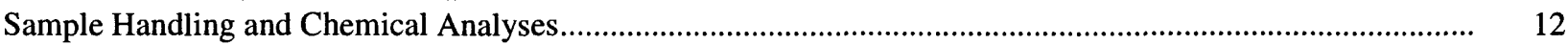

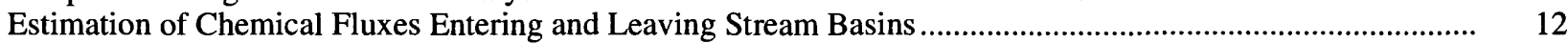

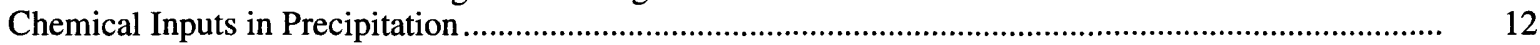

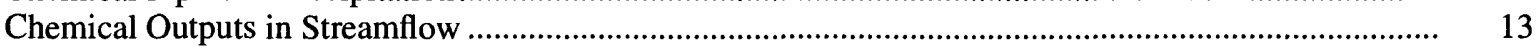

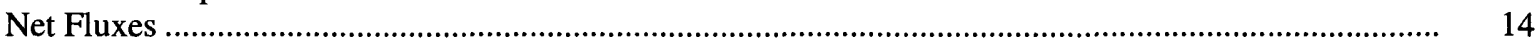

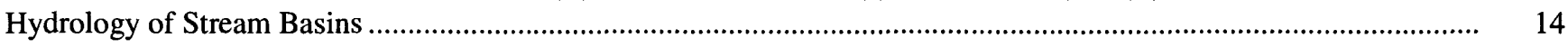

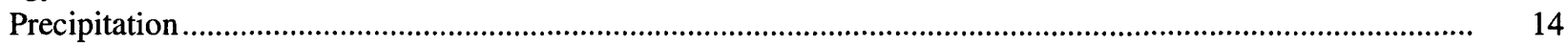

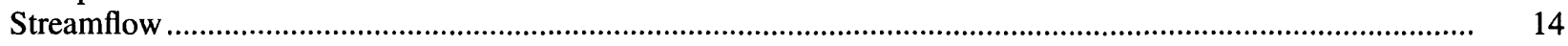

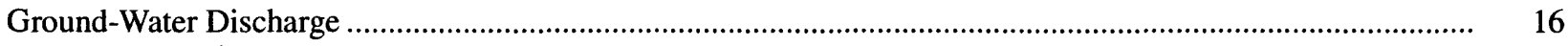

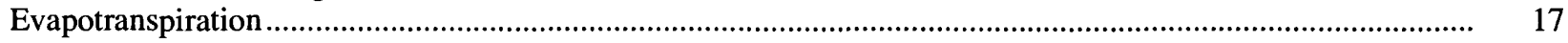

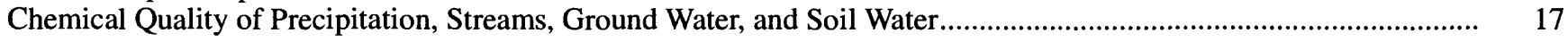

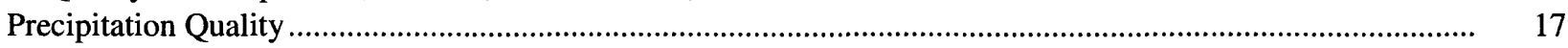

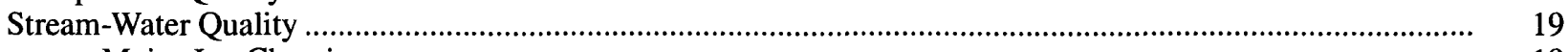

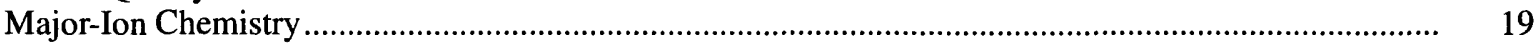

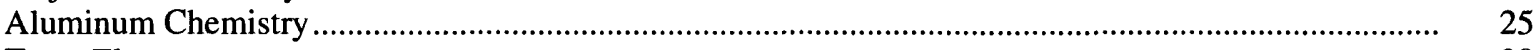

Trace Elements

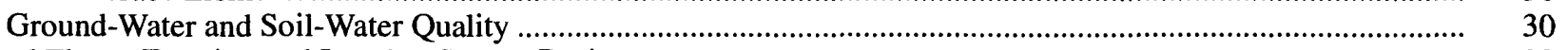

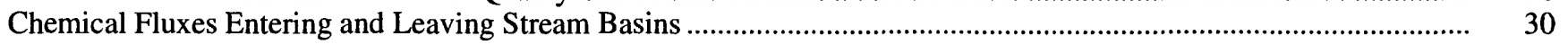

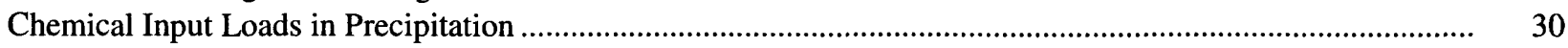

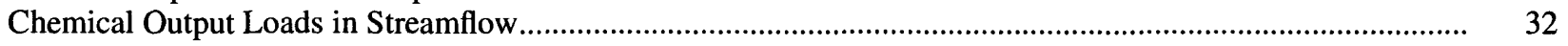

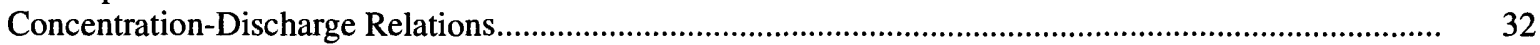

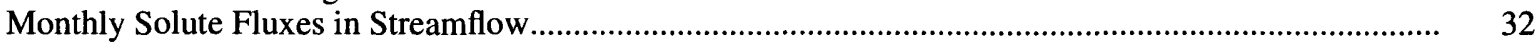

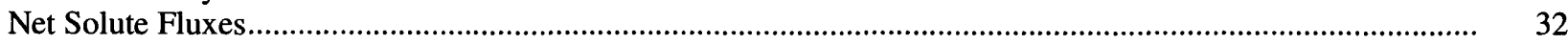

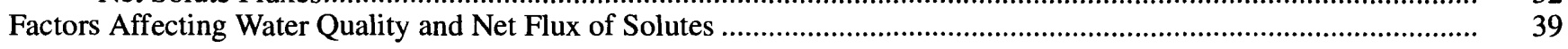

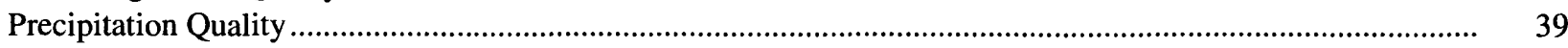

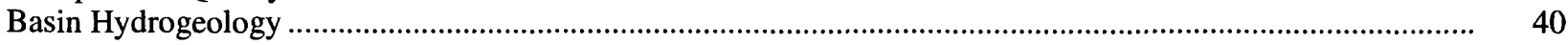

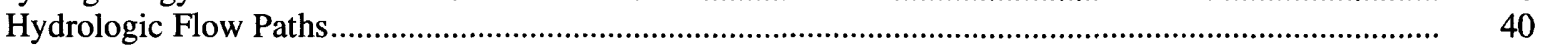

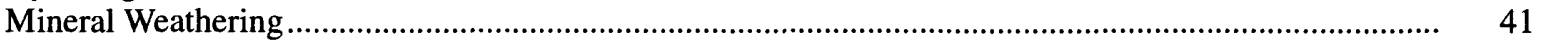

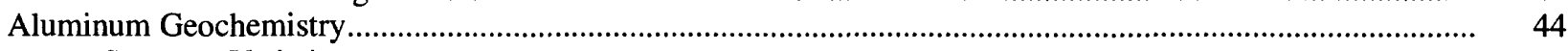

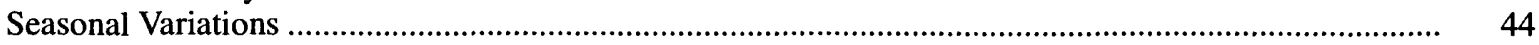

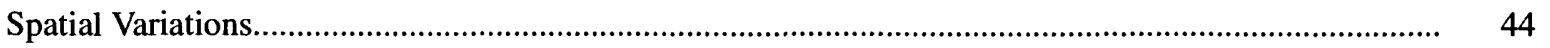

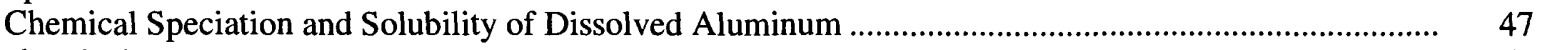

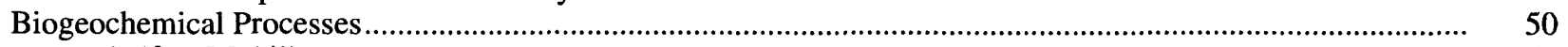

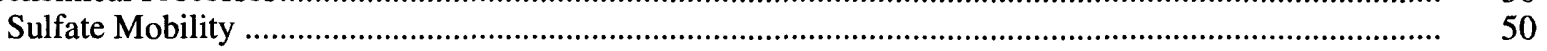

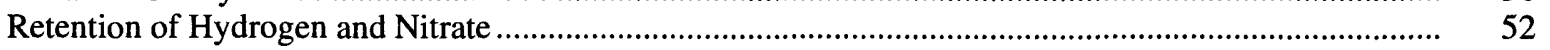

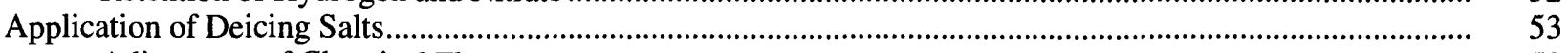

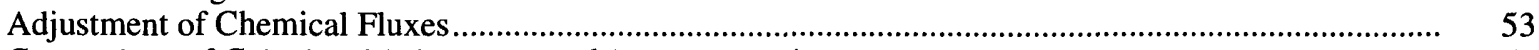

Comparison of Calculated Salt-Export and Salt-Application Data................................................. 57

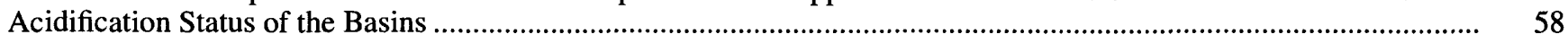

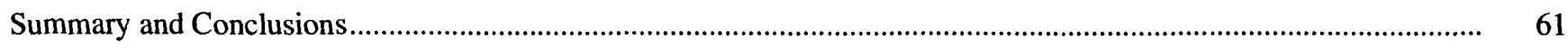

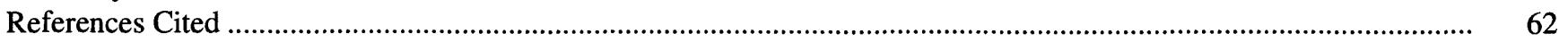




\section{FIGURES}

1-5. Maps showing:

1. Locations of the West Branch Swift River and East Branch Fever Brook Basins, central Massachusetts

2. Lithology of bedrock underlying the West Branch Swift River Basin.

3. Lithology of bedrock underlying the East Branch Fever Brook Basin

4. Surface-water, ground-water, and soil-water sampling sites, West Branch Swift River Basin

5. Surface-water, ground-water, and soil-water sampling sites, East Branch Fever Brook Basin

6-19. Graphs showing:

6. Mean monthly (1943-80) and monthly precipitation (November 1983 through August 1985) at New Salem, Massachusetts....

7. Temporal variation of discharge and base flow, West Branch Swift River and East Branch Fever Brook, December 1983 to September 1985

8. Relations between hydrogen ion concentration and sulfate concentration, and hydrogen ion concentration and sulfate plus nitrate concentration in wet deposition, New Salem, Massachusetts .......

9. Temporal variation of runoff, specific conductance, and concentrations of selected chemical solutes, West Branch Swift River .....

10. Temporal variation of runoff, specific conductance, and concentrations of selected chemical solutes, East Branch Fever Brook

11. Temporal variation of $\mathrm{pH}$ and concentrations of selected chemical solutes, tributaries of West Branch Swift River and East Branch Fever Brook.

12. Relations between aluminum concentrations and $\mathrm{pH}$ in surface water, ground water, and soil water, West Branch Swift River and East Branch Fever Brook

13. Relations between discharge and $\mathrm{pH}$, calcium, alkalinity, and sulfate at West Branch Swift River and East Branch Fever Brook.

14. Composition of water and stability of systems $\mathrm{K}_{2} \mathrm{O}-\mathrm{Al}_{2} \mathrm{O}_{2}-\mathrm{SiO}_{2}-\mathrm{H}_{2} \mathrm{O}$ and $\mathrm{CaO}-\mathrm{Al}_{2} \mathrm{O}_{3} \mathrm{SiO}_{2}-\mathrm{H}_{2} \mathrm{O}$ at 25 degrees Celsius, West Branch Swift River and East Branch Fever Brook Basins..

15. Relations between aluminum concentration and $\mathrm{pH}$, and aluminum concentration and dissolved organic carbon concentration, West Branch Swift River and East Branch Fever Brook Basins

16. Composition of water and stability of dissolved aluminum species in equilibrium with gibbsite and kaolinite at 25 degrees Celsius, West Branch Swift River and East Branch Fever Brook Basins.

17. Relations between sulfate and alkalinity concentrations in West Branch Swift River and East Branch Fever Brook, June through October 1984

18. Charge balance for solute fluxes from the West Branch Swift River and East Fever Brook Basins, December 1983 through August 1985.

19. Relations between calcium plus magnesium concentrations and major anion solutes in stream water in the West Branch Swift River and East Branch Fever Brook

\section{TABLES}

1. Annual hydrologic budgets for West Branch Swift River and East Branch Fever Brook Basins, central Massachusetts.

2. Volume-weighted-average concentrations of solutes in wet deposition, New Salem, Massachusetts

3. Flow-weighted-average concentrations of chemical solutes and runoff data, West Branch Swift River and East Branch Fever Brook, central Massachusetts

4. Summary of mean $\mathrm{pH}$ and chemical solute concentrations at surface-, ground-, and soil-water sampling sites, West Branch Swift River and East Branch Fever Brook Basins, central Massachusetts

5. Monthly loads of chemical solutes in wet deposition, New Salem, Massachusetts

6. Regression-model parameters for specific conductance and major chemical solutes in West Branch Swift River and East Branch Fever Brook, central Massachusetts

7. Estimates of monthly chemical loads in streamflow and monthly runoff, West Branch Swift River and

East Branch Fever Brook, central Massachusetts

8. Fluxes of major solutes and water, West Branch Swift River and East Branch Fever Brook Basins, central Massachusetts. 
9. Saturation index for some minerals for flow-weighted-average base-flow and ground-water samples in

West Branch Swift River and East Branch Fever Brook Basins, central Massachusetts.

10. Chemical speciation of aqueous aluminum in selected water samples from West Branch Swift River and

East Branch Fever Brook Basins, central Massachusetts

11. Composition of rock salt applied in West Branch Swift River and East Branch Fever Brook Basins,

12. Deicing salt-application data, West Branch Swift River and East Branch Fever Brook Basins, central Massachusetts.

13. Chloride load in applied deicing salt and net chloride flux from West Branch Swift River and

East Branch Fever Brook Basins, December 1983 through August 1985

CONVERSION FACTORS AND VERTICAL DATUM

\begin{tabular}{rll}
\hline \multicolumn{1}{c}{ Multiply } & By & To obtain \\
\hline cubic meter $\left(\mathrm{m}^{3}\right)$ & 35.31 & cubic foot \\
cubic meter per second per square kilometer $\left[\left(\mathrm{m}^{3} / \mathrm{s} / \mathrm{km}^{2}\right]\right.$ & 91.49 & cubic foot per second per square mile \\
hectare $(\mathrm{ha})$ & 0.003861 & square mile \\
kilometer $(\mathrm{km})$ & 0.6214 & mile \\
liter $(\mathrm{L})$ & 0.2642 & gallon \\
meter $(\mathrm{m})$ & 3.281 & foot \\
meter per kilometer & 5.28 & foot per mile \\
millimeter $(\mathrm{mm})$ & 0.03937 & inch \\
millimeter per day $(\mathrm{mm} / \mathrm{d})$ & 0.03937 & inch per day \\
square kilometer $\left(\mathrm{km}^{2}\right)$ & 0.3861 & square mile \\
Temperature in degrees Celsius $\left({ }^{\circ} \mathrm{C}\right)$ can be converted to degrees Fahrenheit $\left({ }^{\circ} \mathrm{F}\right)$ as follows: ${ }^{\circ} \mathrm{F}=\left(1.8 \times{ }^{\circ} \mathrm{C}\right)+32$.
\end{tabular}

\section{Vertical Datum}

Sea level: In this report, "sea level" refers to the National Geodetic Vertical Datum of 1929-a geodetic datum derived from a general adjustment of the first-order level nets of the United States and Canada, formerly called Sea Level Datum of 1929. 


\title{
Factors Affecting Water Quality and Net Flux of Solutes in Two Stream Basins in the Quabbin Reservoir Drainage Basin, Central Massachusetts, 1983-85
}

\author{
By Rochelle L. Rittmaster and James B. Shanley
}

\begin{abstract}
The factors that affect stream-water quality were studied in two forested basins in metamorphic schist and gneiss terrane of central Massachusetts. West Branch Swift River (Swift River), which drains 32.9 square kilometers, and East Branch Fever Brook (Fever Brook), which drains 12.6 square kilometers, flow into the northern part of Quabbin Reservoir, which supplies most of the water for metropolitan Boston. Data were collected on the hydrology and major solute chemistry of precipitation, surface water, ground water, and soil water. Spatial and temporal variations in chemistry and relations between chemical changes and hydrologic processes then were used to identify the mechanisms most important in the chemical evolution of water from acidic precipitation to moderately buffered stream water.
\end{abstract}

During the 21-month study period, December 1983 through August 1985, precipitation chemistry was dominated by hydrogen ion (composite $\mathrm{pH}$ 4.23 ), sulfate, and nitrate. Precipitation was 1,546 millimeters during the first 10 months compared to 969 millimeters during the final 11 months of the period, yet chemical inputs to the basins were higher during the second period by 41 percent for hydrogen ion, 44 percent for sulfate, and 36 percent for nitrate. Base-cation inputs were lower in the final 11 months by an amount directly proportional to the decrease in precipitation. The more acidic composition of precipitation during the final 11-month period indicates a shift in storm track from coastal to continental, allowing air masses to acquire acidic precursors from industrialized regions west of the study area.

Stream chemistry was significantly affected by highway deicing salts, particularly in the Fever Brook Basin, where sodium and chloride were the dominant solutes. Some sodium in deicing salt replaced calcium and magnesium on cationexchange sites, resulting in increased export of those base cations in streamflow. At the Swift River outlet gaging station, concentrations of base cations and silica were relatively constant, although moderate dilution occurred at high flows and concentrations increased during base flow in the summer. At the Fever Brook outlet gaging station, base-cation concentrations were more variable than those at the Swift River outlet gaging station, and the dilution of silica was much greater during high flow in spring. At each gaging station, potassium concentrations peaked later in the year relative to concentration peaks of the other base cations because of leaching of potassium from fallen leaves. Alkalinity was less than 50 microequivalents per liter for most of the year at each gaging station, but increased to near 150 microequivalents per liter in summer and early autumn. Organic acidity in stream water at the Fever Brook gaging station caused higher concentrations of dissolved organic carbon, hydrogen ion, and aluminum compared to the Swift River gaging station. However, episodic increases of hydrogen ion and aluminum were more frequent at the Swift River gaging station. Aluminum concentrations increased from less than 100 to nearly 300 micrograms per 
liter during high-flow periods in both streams. The large input of atmospheric sulfate was reflected in flow-weighted mean sulfate concentrations greater than 130 microequivalents per liter in both streams. At the Swift River gaging station, sulfate concentrations were relatively constant, whereas at the Fever Brook gaging station, sulfate concentrations decreased in summer as a result of sulfate reduction in wetlands.

Differences in stream-water quality among tributary sites in each basin can be attributed to variations in geology and hydrology. At Swift River, a subbasin that comprises only 11.2 percent of the total basin area contributed nearly 25 percent of the total base cations, 16 percent of the total silica, and 77 percent of the total alkalinity exported from the basin. This subbasin is underlain by gabbro composed of hornblende and calcium feldspar, rather than the felsic rocks of quartz and sodium and potassium feldspars that underlie most of the remainder of Swift River Basin.

The large inputs of hydrogen ion and nitrate in wet deposition were almost entirely retained in the basins. In contrast, in the Swift River Basin, the output of sulfate in stream water $(1,684$ equivalents per hectare) was 63 percent greater than the input in wet deposition ( 1,034 equivalents per hectare). The net export of 650 equivalents per hectare was attributed predominantly to dry deposition of sulfate, which was not measured. Net export of sulfate from the Fever Brook Basin was only about one-half as much as that from Swift River Basin because of sulfate reduction in the extensive wetlands in Fever Brook Basin during summer and early autumn.

The weathering of hornblende and plagioclase controlled base-cation fluxes at both outlet gaging stations. After correction for the effect of deicing salts, the net flux of base cations was 41 percent greater at $\mathrm{Swift}$ River $(2,014$ equivalents per hectare) than at Fever Brook $(1,429$ equivalents per hectare) for the 21-month study period. The net flux of silica was 58 percent greater at Swift River $(1,260$ moles per hectare) than at Fever Brook (799 moles per hectare). The disproportionately greater export of silica and calcium and the higher calcium:magnesium ratio at Swift River compared to that at Fever Brook indicates that plagioclase weathering is predominant in the Swift River Basin, and that hornblende weathering is predominant in the Fever Brook Basin. The overall weathering rate appears to be greater in the Swift River Basin because of the presence of the easily weathered gabbro in one small subbasin, and because of a higher proportion of ground-water discharge at Swift River relative to that at Fever Brook. The alkalinity is about the same in each basin, however, because the additional alkalinity generated by higher weathering rates at Swift River is balanced by additional alkalinity generated by sulfate reduction coupled with organic carbon oxidation at Fever Brook.

An indication that acidification is occurring in Swift River and Fever Brook is that the sum of equivalents of base cations (primarily calcium and magnesium) is not balanced by bicarbonate alkalinity. Because sulfate concentrations generally were greater than alkalinity, sulfate in the stream water is the dominant anion accounting for transport of base cations from the basins. An important finding of the study was that sodium in highway deicing salts exchanged for calcium and magnesium on soil cation-exchange sites, which resulted in increased export of calcium and magnesium in stream water.

\section{INTRODUCTION}

The potential adverse effects of atmospheric acid deposition, commonly referred to as acid rain, have drawn national and international attention. Researchers in the United States, Canada, and Europe have been investigating the effect of acid deposition on damage to forests, mobility of heavy metals in soil and water, decreasing populations of fish and other aquatic life, and acidification of surface waters (Galloway and others, 1983; Henriksen and others, 1984; Schindler, 1988).

The Quabbin Reservoir in central Massachusetts supplies most of the water demand for the Boston metropolitan area. The reservoir is owned and managed by the Metropolitan District Commission (MDC). Runoff from $485 \mathrm{~km}^{2}$ of drainage basin is impounded in the 
1.56 million $\mathrm{m}^{3}$ reservoir (Nesson, 1983). The $100-\mathrm{km}^{2}$ surface and $190 \mathrm{~km}$ of shoreline also are used for limited recreation.

Records maintained by the MDC indicate that alkalinity in the reservoir has decreased from greater than $200 \mu \mathrm{eq} / \mathrm{L}$ (microequivalents per liter) in the 1940 's to less than $100 \mu \mathrm{eq} / \mathrm{L}$ in 1980 . Increased acidity could result in the mobilization of aluminum, which can affect the quality of drinking water (Sung and others, 1984), and can be toxic to biota (Halliwell, 1985). Fishpopulation declines and some local fish kills have been observed in streams that discharge into the Quabbin Reservoir (DiNardo, 1984; Gelbspan, 1984).

In response to concerns about the effects of acid deposition on water quality and aquatic ecology of the Quabbin Reservoir, the MDC and the Division of Water Pollution Control of the Massachusetts Department of Environmental Protection (then known as the Department of Environmental Quality Engineering) cooperated with the U.S. Geological Survey (USGS) on a 21month study (1983-85) of the hydrology and streamwater quality of two forested drainage basins whose streams discharge into the reservoir. These basins were selected on the basis of different geology and surfacewater hydrology so that various physical and chemical conditions could be considered.

The initial impetus for this study was primarily a concern over the effects of acid deposition on streamwater quality in the Quabbin Reservoir drainage basin. Knowledge of how acidic atmospheric inputs are processed in tributary basins in the drainage basin is vital to assessing the possibility of acidification in the reservoir. The elements of the study included: (1) collection and chemical analysis of wet deposition near the Quabbin Reservoir; (2) collection and chemical analysis of soil-water, ground-water, and stream-water samples, and measurement of stream discharge in the West Branch Swift River and East Branch Fever Brook Basins from December 1983 through August 1985; (3) calculation of fluxes of major chemical solutes entering each drainage basin in wet deposition and leaving in streamflow; and (4) interpretation of spatial and temporal variability of stream-water quality and solute fluxes on the basis of hydrologic, geologic, and biogeochemical characteristics of each drainage basin.

\section{Purpose and Scope}

The purpose of this report is to describe and interpret the processes that affect the net flux of solutes and the quality of stream water that discharges into Quabbin Reservoir. The report describes how solute fluxes and stream-water quality are affected by the quality of precipitation, basin hydrologic characteristics, and mineral weathering processes, with special attention to aluminum geochemistry. Other effects considered are general biogeochemical processes and the application of highway deicing salts. Spatial and temporal variations in solute concentrations and fluxes in stream water are evaluated in light of these potential controlling factors. Finally, the status of the basins with respect to acidification from atmospheric deposition is evaluated. The report details the extensive field sampling effort undertaken to collect the data needed for these interpretations. The study covered a 21 -month period from 1983 to 1985 . The report is intended to provide managers of water resources in the Quabbin Reservoir drainage basin with sound scientific information that will help them guide their water-resources management decisions.

\section{Related Studies}

The bedrock geology of the area around the northern shoreline of the Quabbin Reservoir has been the subject of numerous investigations by the University of Massachusetts, Department of Geology (Makower, 1964; Ashenden, 1973; Michener, 1983). Beginning in the 1980 's, this work was supplemented by a series of hydrogeologic and hydrogeochemical investigations. Batchelder and others (1983) and Yuretich and Batchelder (1988) found that weathering rates in the Fort River Basin near Amherst were greater than rates at Hubbard Brook, N.H., because of differences in weathering processes and hydrogeology. Variations in hydrologic flow paths were the most important factor affecting spatial differences in ground-water chemistry in the adjacent Cadwell Creek Basin (Leonard and others, 1984; Yuretich and others, 1989).

Steckl (1985) contrasted hydrogeologic characteristics of Carter and Mundberry Brooks, two adjacent drainage basins on the northeast side of the Quabbin Reservoir. Although the residence time of ground water was similar in the two basins, weathering rates seemed greater in Carter Brook Basin because of the greater 
areal extent of thicker unconsolidated surficial deposits in the basin compared to Mundberry Brook Basin. The hydrochemistry of these two drainage basins has been studied in greater detail by researchers from the University of Massachusetts (Knapp, 1990; McManamon, 1990) to compare the hydrochemistry of these two drainage basins to that in the Cadwell Creek Basin. A preliminary comparison of the two areas, including derivations of the pertinent weathering reactions that control the stream chemistry, was made by Yuretich and others (1986).

The USGS also has completed studies related to acid deposition in the Quabbin area and in other parts of Massachusetts. Gay and Melching (1994) collected precipitation samples at two sites in the State, and correlated precipitation chemistry with the track of the storm in an effort to relate rainfall acidity to its geographic source. This work was followed by a study in which the liquid and solid phase of incremental precipitation samples were analyzed to better define the geographic origin of the air mass and detecting changes in air masses during storms (Risley and Shanley, 1994).

Another USGS study in the Quabbin area investigated the effects of clearcutting on water quality and quantity (Shanley and others, written commun., 1992). The study used a paired drainage basin approach; one drainage basin was a control and a second drainage basin was partially logged, then limed and planted in rye grass, to ascertain whether this management practice could be used to increase runoff without affecting water quality. Bent (1994) analyzed the hydrologic results of that study. A report tabulating data on which the present report is based was prepared by Rittmaster and Girouard (1992). Finally, Shanley (1994) used data collected as part of the present study to determine that ion exchange of sodium in deicing salt for calcium and magnesium in soil altered the proportions of cations in stream solute fluxes.

\section{Location and Description of Study Area}

The drainage basins selected for study are in the Swift River subbasin of the Chicopee River, one of the major tributaries of the Connecticut River in central Massachusetts. West Branch Swift River Basin, hereafter referred to as Swift River, lies northwest of Quabbin Reservoir and drains $32.9 \mathrm{~km}^{2}$; East Branch Fever Brook Basin, hereafter referred to as Fever Brook, lies northeast of Quabbin Reservoir and drains $12.6 \mathrm{~km}^{2}$ (fig. 1). Altitude at the reservoir is $160 \mathrm{~m}$ above sea level, and altitudes range from 168 to $369 \mathrm{~m}$ above sea level in the Swift River Basin, and from 213 to $372 \mathrm{~m}$ above sea level in the Fever Brook Basin.

The average annual precipitation at New Salem, near the northwest shore of Quabbin Reservoir, is about $1,270 \mathrm{~mm}$, based on 44 years of record (National Oceanic and Atmospheric Administration, 1985a). Average annual snowfall at Worcester, $48 \mathrm{~km}$ southeast of the Quabbin Reservoir, is $1,780 \mathrm{~mm}$, based on 28 years of record. Annual means of daily maximum and minimum temperatures at Worcester are 13 and $3^{\circ} \mathrm{C}$.

Perennial streams in the Swift River Basin are roughly parallel, and generally trend north-south reflecting the significant control of the underlying geologic structure on drainage-pattern development (Thornbury, 1969). Ephemeral tributaries drain ridges with stream gradients of as much as $66 \mathrm{~m} / \mathrm{km}$. The drainage pattern in the Fever Brook Basin consists of irregular stream courses and short tributaries. In the western half of Fever Brook Basin, the hummocky terrain is composed of stratified-drift deposits. The terrain of the Fever Brook Basin generally is less rugged than the terrain of the Swift River Basin. Fever Brook Basin contains natural and manmade impoundments. Prominent features in Fever Brook Basin include Brooks Pond, which covers about $0.65 \mathrm{~km}^{2}$ in the upper part of the basin, and marshy areas in much of the lower half of the basin. In contrast, there is only one small impoundment in the headwater area of the Swift River Basin.

Most of the bedrock in the study area is composed of metamorphosed Paleozoic sediments and volcanics of the Bronson Hill tectonic province (Robinson, 1967). Dominant lithologies include felsic gneiss, schist, amphibolite, quartzite, gabbro, and minor granitic intrusives (figs. 2 and 3). Episodes of folding and faulting during the Acadian Orogeny imposed north-south trending ridges and valleys throughout the region. Bedrock outcrops generally follow the structural trend along ridges and hilltops (Mulholland, 1974). Numerous investigations of the regional bedrock have revealed few faults in the area, and ground-water loss to bedrock fractures is minimal (Yuretich and others, 1986). 


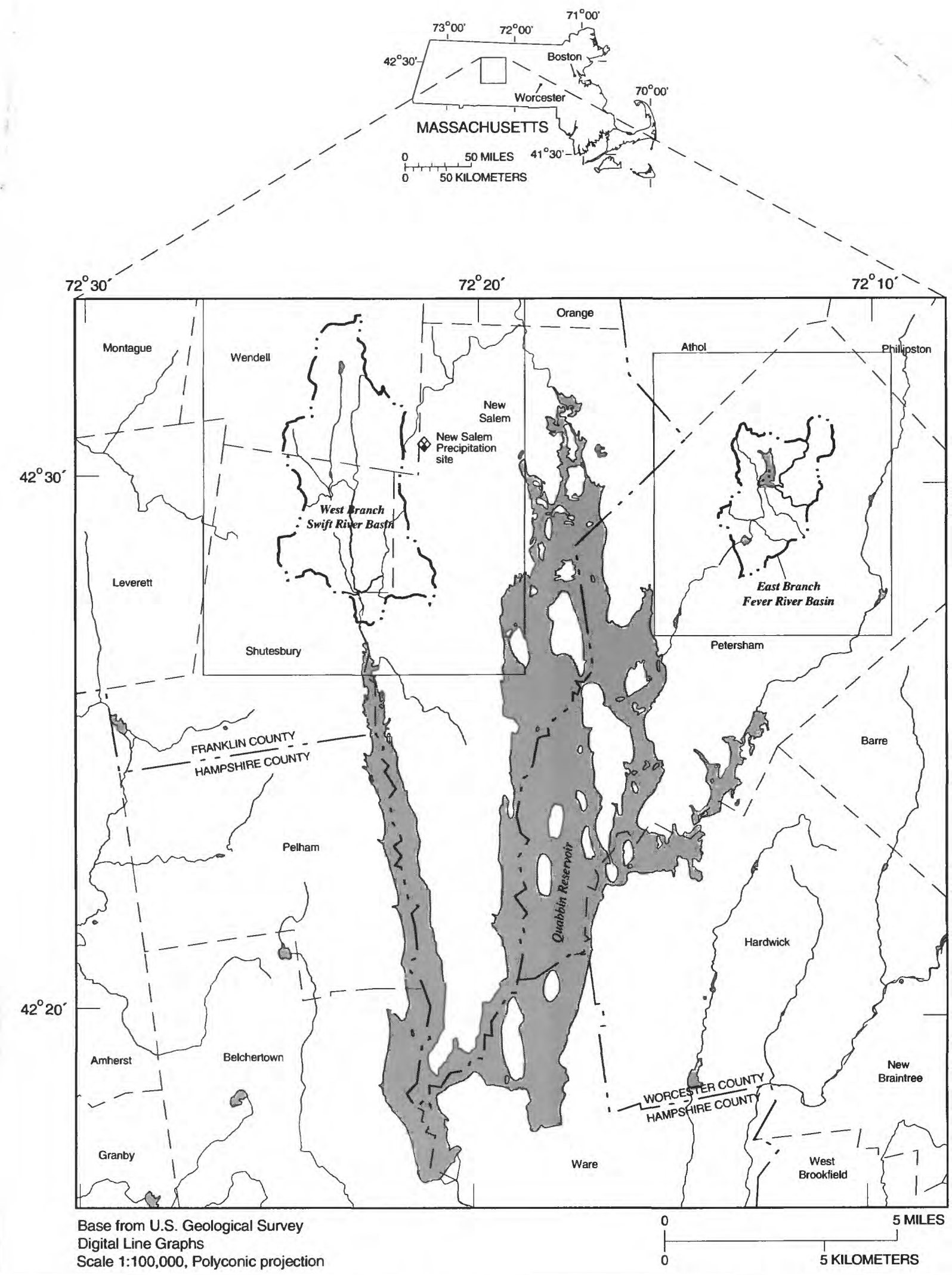

Figure 1. Locations of the West Branch Swift River and East Branch Fever Brook Basins, central Massachusetts. 


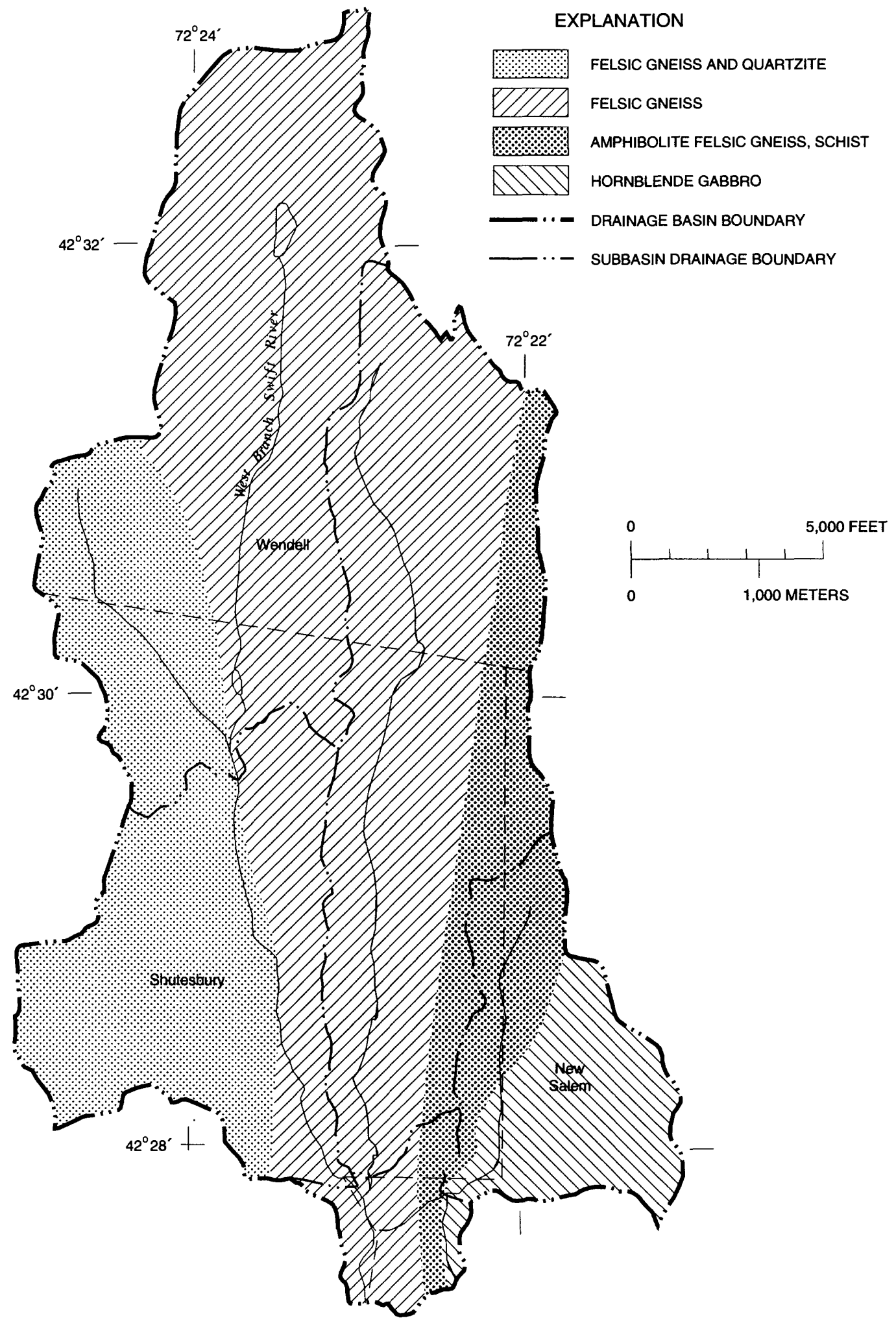

Figure 2. Lithology of bedrock underlying the West Branch Swift River Basin, central Massachusetts. (Geology from Robinson, 1967.) 


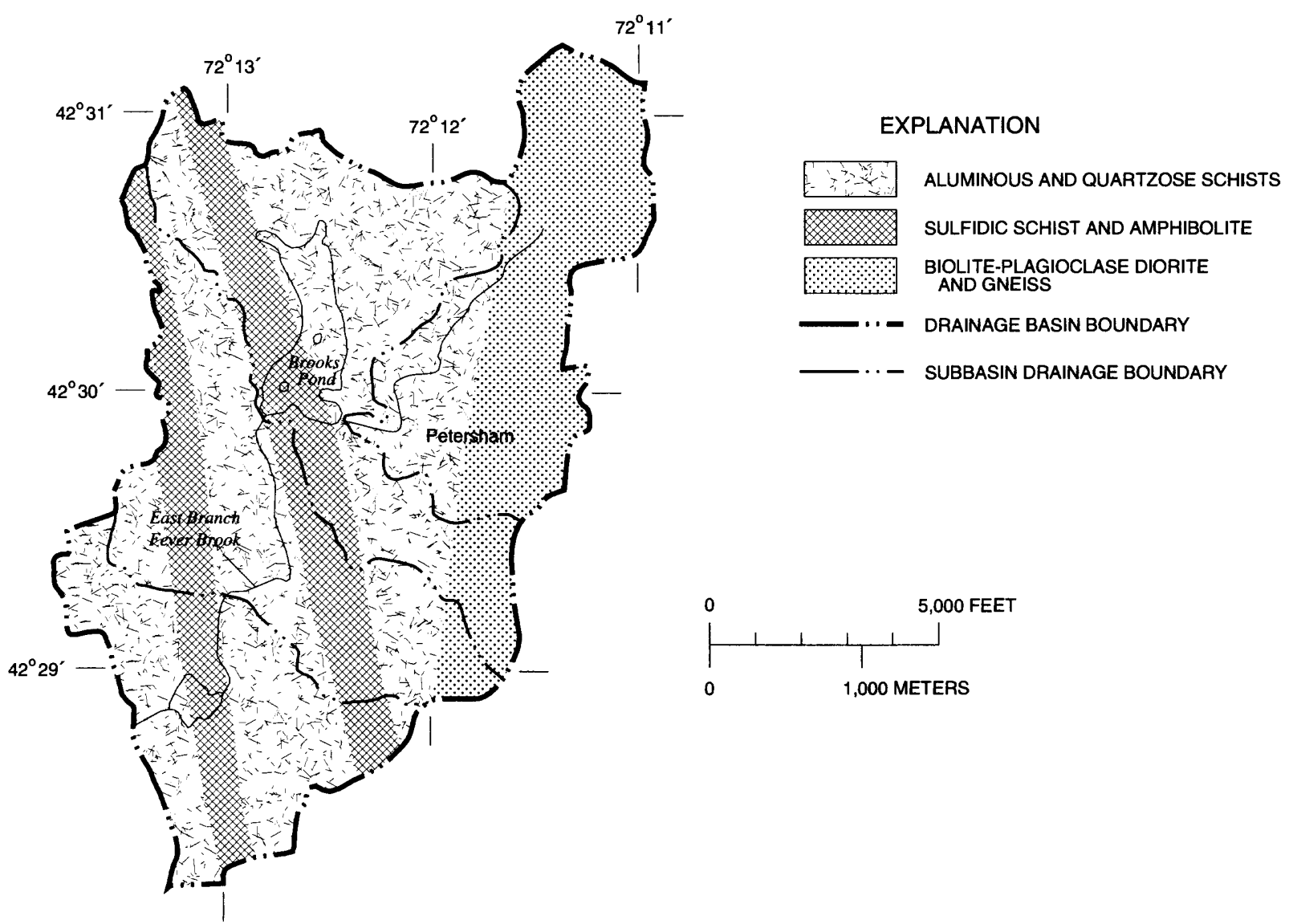

Figure 3. Lithology of bedrock underlying the East Branch Fever Brook Basin, central Massachusetts. (Geology from Robinson, 1967.)

Mantled over the largely impermeable bedrock units are water-bearing unconsolidated materials deposited by glacial processes during the Pleistocene epoch. On the basis of regional reconnaissance mapping of the textures of surficial deposits, Stone and others (1979) delineated two major groups-till and stratified drift. Till, which is more widely distributed, was formed beneath the ice by the movement and abrasion of continental ice sheets over bedrock, or formed as a residue from rock material imbedded in melting ice. Grain size of the typically unstratified and unsorted till ranges from clay to boulder, and thickness is as much as tens of feet (Newton, 1978). Minerals in the till probably are derived from local bedrock; Retelle (1979) found pebbles similar to underlying or nearby bedrock in a study of tills just north of the study area. Stratified drift typically overlies till in valleys but not exclusively. These deposits were formed in running or impounded glacial meltwater and commonly are well sorted. Grain size of the stratified-drift layers ranges from silt to gravel (Mulholland, 1974; Stone and others, 1979). Stratified-drift deposits can be areally extensive, as in a kame plain or terrace, or of local areal extent, as in an esker (Eschman, 1966).

The combined effects of glaciation and local bedrock geology have resulted in distinctly different terrains in the two basins. Glacier movements over belts of resistant gneisses and less-resistant schists in the Swift River Basin produced a terrain of steep ridges and exposed bedrock that alternate with valleys filled with tens of feet of unconsolidated till and stratified drift. In contrast, the Fever Brook Basin, which is underlain primarily by schist, consists of gentle slopes with few ridges and exposures of bedrock. Stratified drift composes 13 and 18 percent of surficial deposits in the Swift 
River and Fever Brook Basins, respectively (D.D. Ashenden, Metropolitan District Commission, written commun., 1986).

The major mineral composition also differs in the two basins. The diverse mineralogy of the bedrock underlying the Swift River Basin reflects the variability of bedrock geology (Makower, 1964; Ashenden, 1973; Michener, 1983; Shearer, 1983). One part of the Four Mile Gneiss, which underlies a large percentage of the drainage basin, is biotite-feldspar gneiss and amphibolite. These rocks are composed of microcline, sodic plagioclase, biotite, quartz, and hornblende. The Erving and the Mount Mineral Formations, which also underlie part of the basin, have amphibolites that contain hornblende and epidote. The Littleton Formation has muscovite and sodic plagioclase (albite) as major minerals. In the southeast part of the basin, the dominant lithology is a gabbro member of the Prescott Complex that contains 50 to 72 percent hornblende, and calcic plagioclase (labradorite). The Cooleyville Granitic Gneiss, also in the southeastern subcatchment, is a fine-grained gneiss primarily composed of andesine-a plagioclase intermediate in calcium content to the plagioclase in the Four Mile Gneiss and that in the Prescott Complex.

The Fever Brook Basin is underlain by large bands of the Littleton and the Rangely Formations and minor stringers of the Monson Gneiss and Hardwick Tonalite. The Littleton is composed of aluminous schist and phyllite (predominantly muscovite and albite, but containing some biotite and chlorite). The major mineral assemblages of rocks in the Rangely Formation include: (1) a sulfidic mica schist composed of quartz, muscovite, biotite, sillimanite, and sodic-rich plagioclase, as well as some iron sulfides; and (2) amphibolite, composed predominantly of hornblende.

The soils in both basins are classified as inceptisols (U.S. Department of Agriculture, 1975)-immature soils with poorly developed horizons. Soils derived from stratified drift contain large amounts of sand and gravel and generally are less than $60 \mathrm{~cm}$ (centimeters) deep (Lyford, 1964a). Soils derived from till are stony and gravelly and may have localized hardened layers (Patric and Lyford, 1980). The drainage of these silty, low-clay soils is moderate to good but may be poor in closed depressions (Lyford, 1964b). Soil samples collected in the Swift River and Fever Brook Basins are described by Rittmaster and Girouard (1992). The O horizon consists of fresh and decomposed organic material, and the loamy A horizon consists of mineral soil and organic matter. A weakly developed but extensive B horizon is only slightly altered from the parent material. Yellowish and reddish mottling indicates oxidation to ferric minerals in this horizon. Underlying the $\mathrm{B}$ horizon is a virtually unaltered $\mathrm{C}$ horizon composed of sandy and silty material from the stratified drift and till parent materials. The descriptions of the soil profiles from the Swift River and Fever Brook Basins were similar to the description of an inceptisol developed on glacial deposits in the Cadwell Creek Basin, about $14 \mathrm{~km}$ south of the Swift River Basin (Leonard and others, 1984).

The dominant clay mineral (less than $2 \mu \mathrm{m}$ ) in nearly all soil samples from the two basins was vermiculite (Rittmaster and Girouard, 1992). Minor amounts of illite and kaolinite also were present in nearly all samples. Chlorite was a major clay mineral in some samples. Gibbsite was relatively abundant in samples from the Swift River Basin but was detected in only one of six samples from the Fever Brook Basin.

Four soil profiles from each basin were analyzed for $\mathrm{pH}$, exchangeable cations, and cation-exchange capacity (CEC) (Rittmaster and Girouard, 1992). CEC in both basins ranged from 0.5 to $12 \mu \mathrm{eq} / 100 \mathrm{~g}$; base saturation ranged from 15 to 96 percent at Swift River, and from 10 to 57 percent at Fever Brook. In general, CEC was highest in surface soil (O horizon), and decreased with depth. Percentage of base saturation tended to increase with soil depth. Soil-slurry $\mathrm{pH}$ generally ranged from 3.7 to 4.2 in the organic horizons to 4.4 to 4.6 in the deeper mineral soil.

Historically, the land has been sparsely settled. Remnants of settlements include extensive sections of stone walls and breached small dams. Both drainage basins are forested with a mixture of deciduous and coniferous vegetation, including red oak, white ash, red maple, sugar maple, and white pine. The canopy reaches a height of $18 \mathrm{~m}$, indicative of several decades of generally undisturbed growth.

\section{Acknowledgments}

The authors acknowledge State and local government personnel, and local residents who provided time and information to this study. The authors express gratitude to Mr. David Ashenden and Mr. Bruce Spencer, of the Metropolitan District Commission, for their on-site 
work and contributions to the study; to Norman LaPointe of the Petersham Department of Public Works, who provided information on deicing-salt application in Fever Brook Basin; and to Elizabeth Knapp and Ann McManamon of the University of Massachusetts, who provided chemical data from their study area adjacent to Fever Brook Basin.

\section{METHODS OF STUDY}

A data-collection network (figs. 4 and 5) was established to measure the various components of the chemical and the hydrologic budgets. Chemical and hydrologic mass balances were computed as the difference between chemical and hydrologic inputs in precipitation and outputs in stream water. Adjustments were made for solutes affected by the application of deicing salts in the drainage basins. Data were collected from December 1983 to August 1985. Site descriptions and basic data from these sites are in Rittmaster and Girouard (1992).

\section{Sampling and Data Collection}

\section{Precipitation}

Samples of wet deposition were collected with a wetfall-dryfall collector (Aerochem Metrics Model $301^{1}$ ) in New Salem (fig. 4). The collector was operated in a field on private property from December 1983 through March 1985. In April 1985, the collector was moved $0.8 \mathrm{~km}$ to a site on MDC property. Weekly composite samples were collected each Tuesday to coincide with the sampling schedule established by the National Atmospheric Deposition Program (Bigelow, 1982). Daily volume of precipitation was recorded at the National Oceanic and Atmospheric Administration (NOAA) site at New Salem (National Oceanic and Atmospheric Administration 1983, 1984, 1985b). New Salem is between the two basins. Precipitation quantity and quality at New Salem was assumed to be representative for the two basins. Local variations in precipitation quantity and quality may introduce errors into the hydrologic and chemical budgets for Swift River and Fever Brook.

\footnotetext{
${ }^{1}$ Use of trade names or brand names in this report is for identification purposes only and does not constitute endorsement by the U.S. Geological Survey.
}

\section{Streamflow}

A continuous-record gaging station was established at the outlet of each basin (figs. 4 and 5). Samples of stream water were collected approximately weekly for chemical analysis; additional samples were collected during some storms and snowmelt periods. Chemical data were used to evaluate water-quality changes related to time, season, and hydrologic conditions. Instantaneous discharge and stream stage were measured concurrently with most sample collections during water year ${ }^{2} 1984$ to establish the stage-discharge rating curve. Spot measurements of instantaneous discharge during water year 1985 were made to verify the stage-discharge relation.

Records of stream stage were adjusted for effects from ice, vegetation, and beaver impoundments, based on weather records and field observations. Corrected stage records were converted to discharge using a rating curve developed from measurements of instantaneous discharge over a broad range of stages. Mean discharge at each outlet gaging station was calculated at a daily time step.

Stream discharge was partitioned into base flow, which is the ground-water component, and direct runoff that enters the stream system during and shortly after precipitation and snowmelt (Hem, 1985). The relative proportion of the ground-water component of streamflow was determined by use of the daily mean discharge hydrograph and standard graphical separation techniques (Davis and DeWiest, 1966).

Water samples were collected at four sites on tributaries of Swift River and at three sites on tributaries of Fever Brook Basin during snowmelt, summer low flow, and autumn and winter base flows. Analyses of these samples were used to evaluate spatial variability of water quality related to local bedrock geology, surficial geology, and hydrologic conditions in the basin. Because the waters were well mixed (specific conductance, $\mathrm{pH}$, and temperature across the channels were uniform), except at the Swift River gaging station, grab samples were collected at all stream-sampling sites. The Swift River gaging station was downstream from the confluence of a tributary to the mainstem, and water was incompletely mixed $(\mathrm{pH}$ and specific conductance

\footnotetext{
${ }^{2}$ The water year runs from Oct. 1 to Sept. 30 and is designated by the calendar year in which it ends. Thus, the year ending September 30, 1984, is called the "1984 water year."
} 


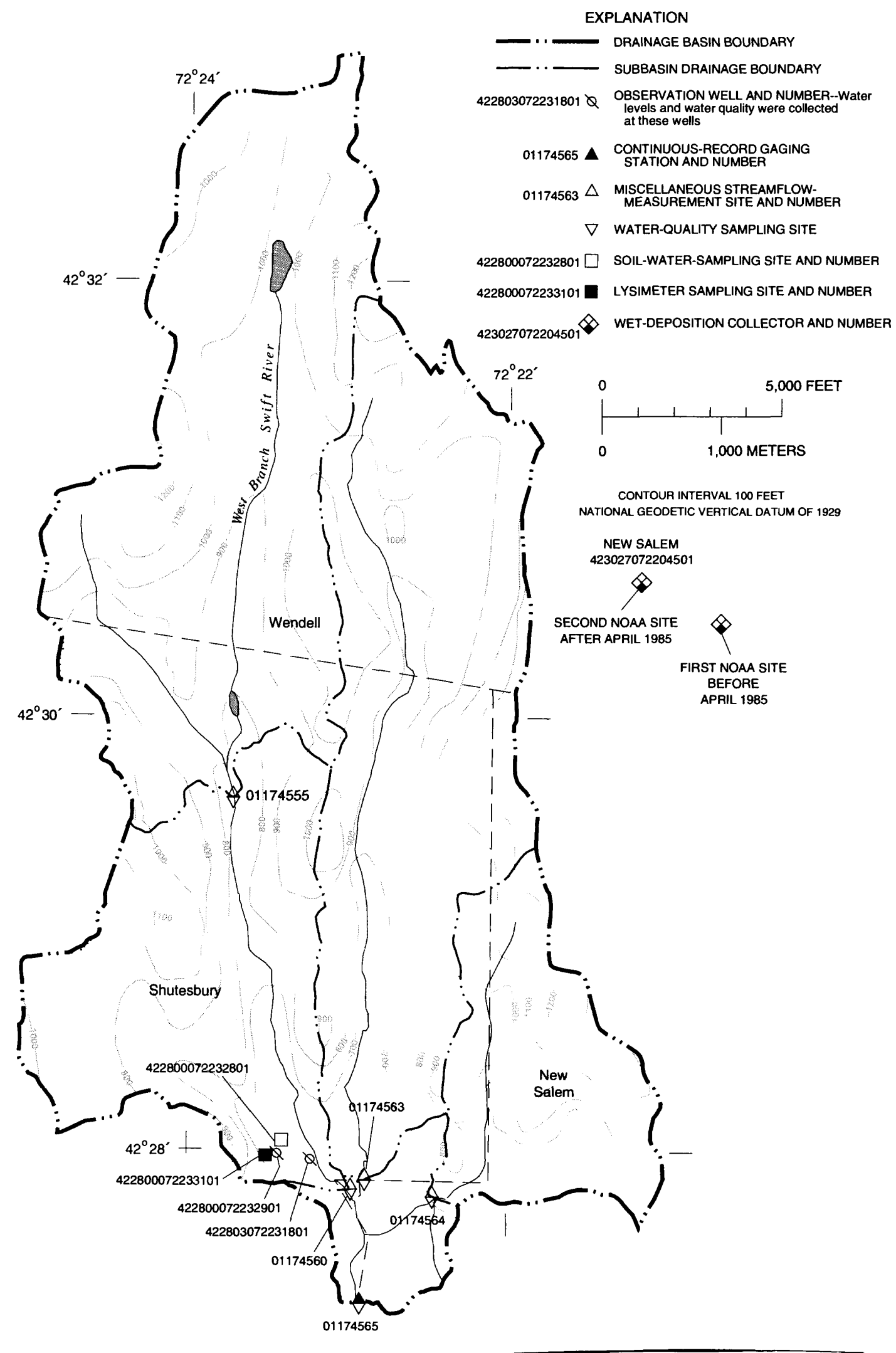

Figure 4. Surface-water, ground-water, and soil-water sampling sites, West Branch Swift River Basin, central Massachusetts. 


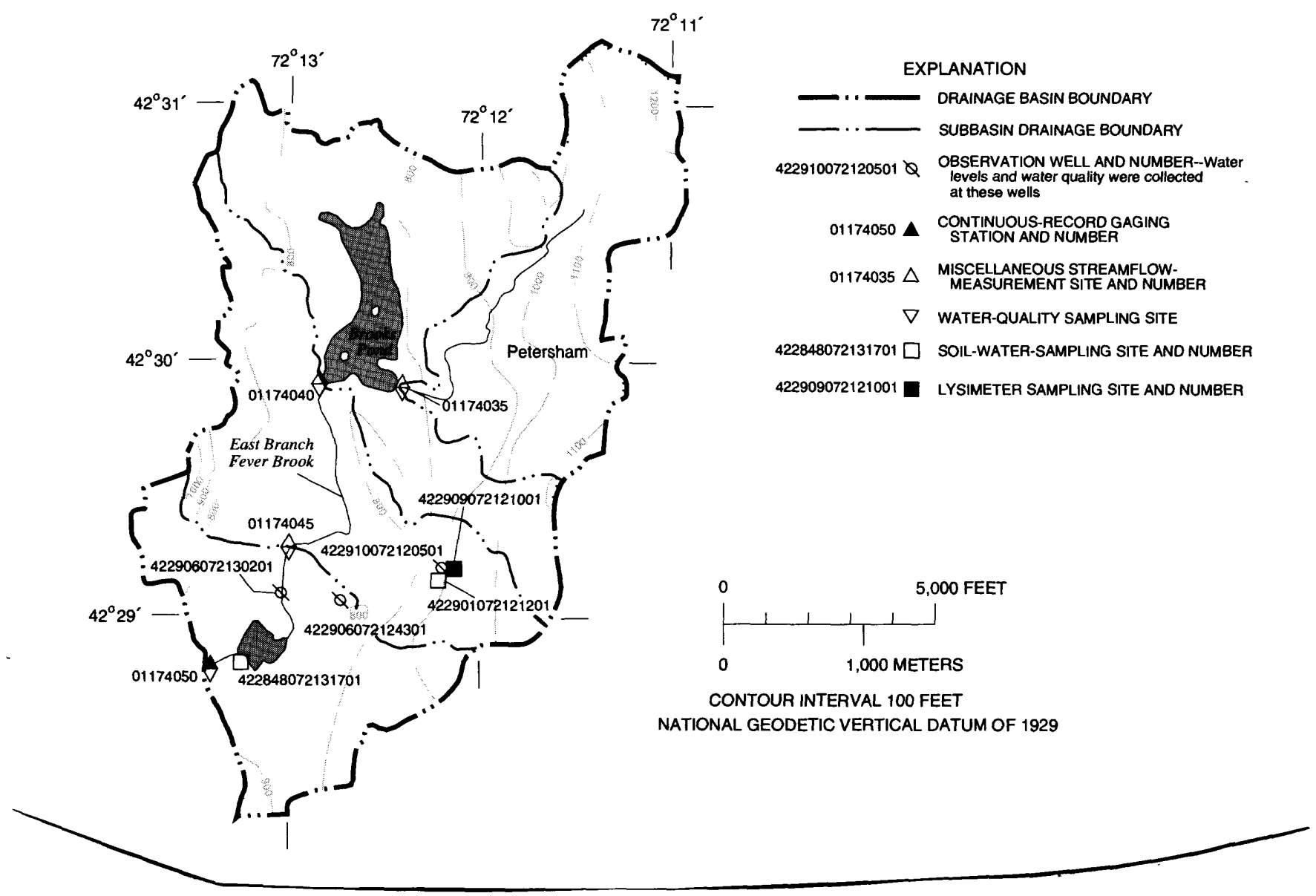

Figure 5. Surface-water, ground-water, and soil-water sampling sites, East Branch Fever Brook Basin, central Massachusetts.

varied laterally across the channel). Therefore, samples were collected at several points across the stream channel and composited.

\section{Ground Water and Soil Water}

Five monitoring wells cased with polyvinyl chloride (PVC) were sampled for chemical analysis of ground water in order to monitor hydrologic and chemical changes in the saturated zone (figs. 4 and 5). Three wells were completed in till, and two were completed in sand and gravel. Water levels in the wells were measured approximately monthly, and ground-water samples were collected monthly to bimonthly. At least three well volumes of water were evacuated from the sand and gravel wells before sampling. Because the till wells recharged very slowly, sometimes only two well volumes were evacuated from them prior to sampling. Two types of soil-water collectors were installed: (1) a zerotension lysimeter, referred to as a "soil-water sampler," consisting of a 5-m PVC trough oriented with the slope, inserted laterally under a 150 -mm segment of soil lifted gently from one side to minimize disturbance, and (2) a negative-tension TIMCO lysimeter with a porous Teflon cup, referred to as a "lysimeter." Few soil-water samples were collected due to rapid infiltration and drainage of water from the silty, permeable soil. Sufficient quantities of water were available for sampling only under conditions of high soil moisture, for example, during spring snowmelt and directly after rainstorms. One soil-water sampler was installed in the Swift River Basin; two were installed in the Fever Brook Basin (figs. 4 and 5). Two to four samples were collected at each location during the study. One site in each drainage basin was equipped with an array of three lysimeters at three different depths, about 100, 300, and 
$600 \mathrm{~mm}$ below land surface. Water was recovered from only the deep lysimeter in the Swift River Basin and from the deep and medium depth lysimeters in the Fever Brook Basin. Water yield varied among samplers. Some sample volumes were sufficient only for $\mathrm{pH}$ and specific conductance measurements but some volumes were sufficient for full chemical analyses $(\mathrm{pH}$, specific conductance, major cations and anions).

\section{Sample Handling and Chemical Analyses}

Temperature, specific conductance, and $\mathrm{pH}$ were measured in the field at the time of sample collection, except for precipitation samples, which first were returned to the laboratory for volume determination and melting if necessary. Specific conductance was measured with an Extech digital conductivity meter and $\mathrm{pH}$ was measured with an Extech model 609 digital $\mathrm{pH}$ meter equipped with an Orion combination glass $\mathrm{pH}$ electrode. These instruments were specifically designed for measurements in low-conductivity waters.

Samples were filtered, preserved, and chilled in the field in accordance with methods recommended by the USGS (Fishman and Friedman, 1989). Samples were shipped chilled to the USGS laboratory in Doraville, Georgia, for chemical analysis. An aliquot of each sample was retained for measurement of alkalinity in the USGS laboratory in Boston.

Alkalinity was measured by incremental, rather than fixed-endpoint titration (Fishman and Friedman, 1989). The endpoint in the incremental titration method is determined as the titrant volume at which the $\mathrm{pH}$ decreases most quickly with incremental additions of titrant. In contrast, fixed-endpoint titration requires acid titration of the sample to a fixed $\mathrm{pH}$, usually 4.3 or 4.5 . Because alkalinity concentration in most water samples collected in the study area was low, the threshold of buffering was at a significantly higher $\mathrm{pH}$ (5.0 to 5.3) than that assumed for a fixed-endpoint titration. Therefore, the alkalinity measured by incremental titration was a more conservative and accurate determination of the buffering capacity of the water than that measured in a fixed-endpoint titration.

Concentrations of major ions in all water samples were determined by analytical methods outlined by Fishman and Friedman (1989). Many of these methods were developed for analysis of dilute waters (specific conductance less than $100 \mu \mathrm{S} / \mathrm{cm}$ ) that are typical of the study area. In addition, total and dissolved concentrations of aluminum, copper, lead, arsenic, vanadium, selenium, and mercury were analyzed for selected samples.

The original sampling protocol called for filtration of all samples through a $0.4-\mu \mathrm{m}$ pore-size membrane. However, Jones and others (1974) found that particulate and colloidal aluminum can pass through a $0.4-\mu \mathrm{m}$ pore-size filter, causing overestimates of monomeric aluminum concentrations, the form of aluminum that is most toxic to fish (Driscoll and others, 1980). Therefore, the filter size was changed to $0.1 \mu \mathrm{m}$. Periodically during the first year of sample collection, two aliquots of each sample were submitted for analysis of aluminum, one which passed through a $0.4-\mu \mathrm{m}$ filter and one which passed through a $0.1-\mu \mathrm{m}$ filter. From 19 split samples, aluminum concentrations averaged $123 \mu \mathrm{g} / \mathrm{L}$ (micrograms per liter) (standard deviation $75 \mu \mathrm{g} / \mathrm{L}$ ) in the $0.4-\mu \mathrm{m}$ filtered samples and $73 \mu \mathrm{g} / \mathrm{L}$ (standard deviation $65 \mu \mathrm{g} / \mathrm{L}$ ) in the $0.1-\mu \mathrm{m}$ filtered samples. This was a statistically significant difference; probability was less than 0.0005 that this difference occurred by chance $(p<0.0005)$. Thus, some particulate or colloidal aluminum apparently passed through the larger pore size. Aluminum concentrations from $0.1-\mu \mathrm{m}$ filtered samples were reported when available, including all samples collected after December 1, 1984.

\section{Estimation of Chemical Fluxes Entering and Leaving Stream Basins}

\section{Chemical Inputs in Precipitation}

Loads of major chemical solutes entering the drainage basin in wet deposition were determined from concentrations of weekly composite samples and precipitation volume corresponding to the sampling period. The general equation to determine the weekly load was:

$$
\text { Load }=A \times B \times C \text {, }
$$

where

$A$ is concentration of a given solute from a weekly composite sample, in milligrams per liter;

$B$ is the total precipitation recorded for the period, in inches; and

$C$ is the constant for converting inches of precipitation to cubic meters of water per 
hectare, liters to cubic meters and milligrams to equivalents such that load units are equivalents per hectare.

An estimate for the weekly load was substituted when: (1) sample integrity was compromised due to equipment malfunction or vandalism, including contamination by leaves, insects, and other dryfall material; or (2) sample volume was insufficient for chemical analysis. The estimate was made by first calculating a volume-weighted concentration of each solute for the 2-week periods before and after the missing week and then multiplying the actual precipitation volume for the missing week by the calculated volumeweighted concentrations. This estimation method incorporated potential seasonal variability of solute concentrations in precipitation. Although deposition of the acidic components of precipitation was unrelated to season (Samson, 1987), the use of 4 weeks of data for computing an average was expected to yield a reliable estimate of solute load for the missing week.

\section{Chemical Outputs in Streamflow}

Relations between solute concentrations and discharge at the Swift River and Fever Brook gaging stations were explored to determine if a sufficiently strong relation could be derived to calculate solute loads. A concentration/discharge relation uses discharge data, which generally were collected at a short enough time step to be considered continuous, to compute a chemical concentration at any time. This was desirable when chemical data were available only from samples collected at widely spaced time intervals. If the relation is sufficiently strong, a continuous chemograph can be generated with confidence. If the relation is weak, the approach is not justified, and loads are best calculated using a time-series approach, as described below. Success in correlating concentration and discharge can be improved by choosing an appropriate regression model. Various models can be created by performing transformations on the discharge variable, such as that used by Johnson and others (1969). Concentration/ discharge relations were evaluated with the following four linear regression models:

$$
\begin{gathered}
Y=m(X)+b, \text { linear model (model no. } 1) \\
Y=m[\log (X)]+b \log \text { linear model (model no. } 2)
\end{gathered}
$$

$$
\begin{gathered}
Y=m[1 / 1+\beta X]+b, \text { hyperbolic model tested with } \\
\text { eight values of } \beta \text { (model no. } 3) \\
Y=m(1 / X)+b, \text { inverse model (model no. } 4),
\end{gathered}
$$

where

$Y \quad$ is the response variable representing solute concentration;

$m$ is the equation coefficient;

$X$ is the explanatory variable representing the instantaneous discharge per unit area;

$b$ is the equation constant; and

$\beta$ is an empirical constant.

In addition to calculating the equation coefficient and constant for each concentration/discharge model, the coefficient of determination $\left(r^{2}\right)$ also was calculated. The $r^{2}$ value represents the proportion of the variability in the response variable $(Y)$ that is accounted for by the model. Analogous to the calculation of chemical loads in precipitation, chemical loads in streamflow were calculated as the product of discharge and chemical concentration. Loads were calculated at a daily time step. Daily mean discharge was computed from 15-minute stage measurements at each gaging station. Daily solute concentrations were either computed from concentration/discharge regression models or estimated by the time-series method.

Solute concentrations were computed from concentration/discharge regression models, using the regression equation with the highest $r^{2}$, provided a minimum $r^{2}$ of 0.40 was achieved. R. Hooper (U.S. Geological Survey, written commun., 1990) recently demonstrated that a concentration/discharge model with an $r^{2}$ greater than 0.30 yields a reliable estimate of load. However, an $r^{2}$ of 0.40 was chosen here because it represents a natural grouping in the data among those solutes that were strongly correlated with discharge and those that were not. Although the regressions were based on the instantaneous discharge associated with each solute concentration, daily mean concentrations were calculated from daily mean discharge. Depending on the nature of the relation, this approximation may lead to errors, especially for days on which discharge varies. Nonetheless, it is common practice to compute daily loads in this manner (R. Hooper, U.S. Geological Survey, written commun., 1990).

The time-series method (Dolan and others, 1981) was used to estimate daily concentrations when the concentration/discharge model had an $r^{2}$ less than 0.40 . 
In the time-series method, daily solute concentrations were set equal to those measured in the stream sample collected nearest in time. Because samples typically were collected on a weekly basis, the concentration of a solute on the sampling day generally was assigned to the days beginning 3 days prior to sampling and ending 3 days after sampling. The assignment of daily concentration values diverged from this schedule when samples were collected more frequently. As above, daily loads were calculated as the product of daily mean discharge and the assigned daily concentrations.

\section{Net Fluxes}

Chemical loads in precipitation and streamflow represent the best estimate of total fluxes of chemical solutes entering and leaving the basins. Net flux, the difference between the input and output of a chemical solute (Shaffer and Galloway, 1982), indicates whether solutes are retained or released from the drainage basin. A negative net flux (stream load greater than precipitation load) indicates a net mass transfer of a solute from the drainage basin. Negative net fluxes could reflect processes in the drainage basin that contribute solutes to water, such as mineral weathering (Bricker and others, 1968; Katz and others, 1985) or biomass decomposition. A positive net flux (stream load less than precipitation load) indicates that a solute introduced in precipitation was retained in the drainage basin, for example by biological uptake, sorption, ion exchange, or mineral precipitation.

Net solute outputs were adjusted to account for deicing salts applied to roads passing through the basins. In the Swift River Basin, the adjustment was based on the assumption that chloride is conservative; equivalents of excess chloride (after accounting for chloride in precipitation) were balanced by equivalents of base cations in the ratio that they are present in the salt (mostly sodium). In the Fever Brook Basin, where salt application was quantitatively a greater percentage of chemical input than in Swift River Basin, this method could not be used because of the effect of ion-exchange reactions. An alternate method was devised and is explained in a later section, "Application of Deicing Salts."

\section{HYDROLOGY OF STREAM BASINS}

\section{Precipitation}

The amount and distribution of precipitation differed greatly from water year 1984 to water year 1985 (fig. 6). Historically, precipitation at New Salem averages about $100 \mathrm{~mm}$ per month, fairly evenly distributed throughout the year (National Oceanic and Atmospheric Administration, 1985a). From December 1983 through July 1984, precipitation was well above average; $338 \mathrm{~mm}$ fell in May 1984. This period was followed by a long period of mild to moderate drought, during which precipitation was less than average each month from August 1984 through July 1985.

\section{Streamflow}

In water year 1984, when precipitation was well above average, runoff per unit area was significantly greater in the Swift River Basin than in the Fever Brook Basin (table 1). Total precipitation of $1,546 \mathrm{~mm}$ resulted in $915 \mathrm{~mm}$ of runoff in the Swift River Basin and $744 \mathrm{~mm}$ runoff in the Fever Brook Basin, corresponding to runoff of 59.2 and 48.1 percent, respectively. In water year 1985, when precipitation was less than average, runoff was nearly identical in the two basins. Runoff from $969 \mathrm{~mm}$ of total precipitation was $285 \mathrm{~mm}$ in the Swift River Basin and $290 \mathrm{~mm}$ in the Fever Brook Basin, corresponding to runoff of 29.4 percent and 29.9 percent, respectively. Normalized to a 12-month period, average runoff from December 1983 through August 1985 was $686 \mathrm{~mm}$ in the Swift River Basin and $591 \mathrm{~mm}$ in the Fever Brook Basin. These figures are comparable to long-term average annual runoff at two similar streams in central Massachusetts, East Branch Swift River near Hardwick, and Cadwell Creek near Belchertown, which averaged 551 and $661 \mathrm{~mm}$, respectively (Gadoury and others, 1989).

Differences in the magnitude of streamflow from 1984 to 1985 at the Swift River and Fever Brook gaging stations are apparent from the discharge hydrographs (fig. 7). Snowmelt and heavy spring rains resulted in high flows in 1984. A 5-day rainstorm of $230 \mathrm{~mm}$ in late May 1984 caused a 50-year flood. Flow decreased in both streams from June to mid-October 1984, reflecting increased evapotranspiration and little precipitation in the summer. Flow generally increased from autumn through early spring because of increased precipitation 


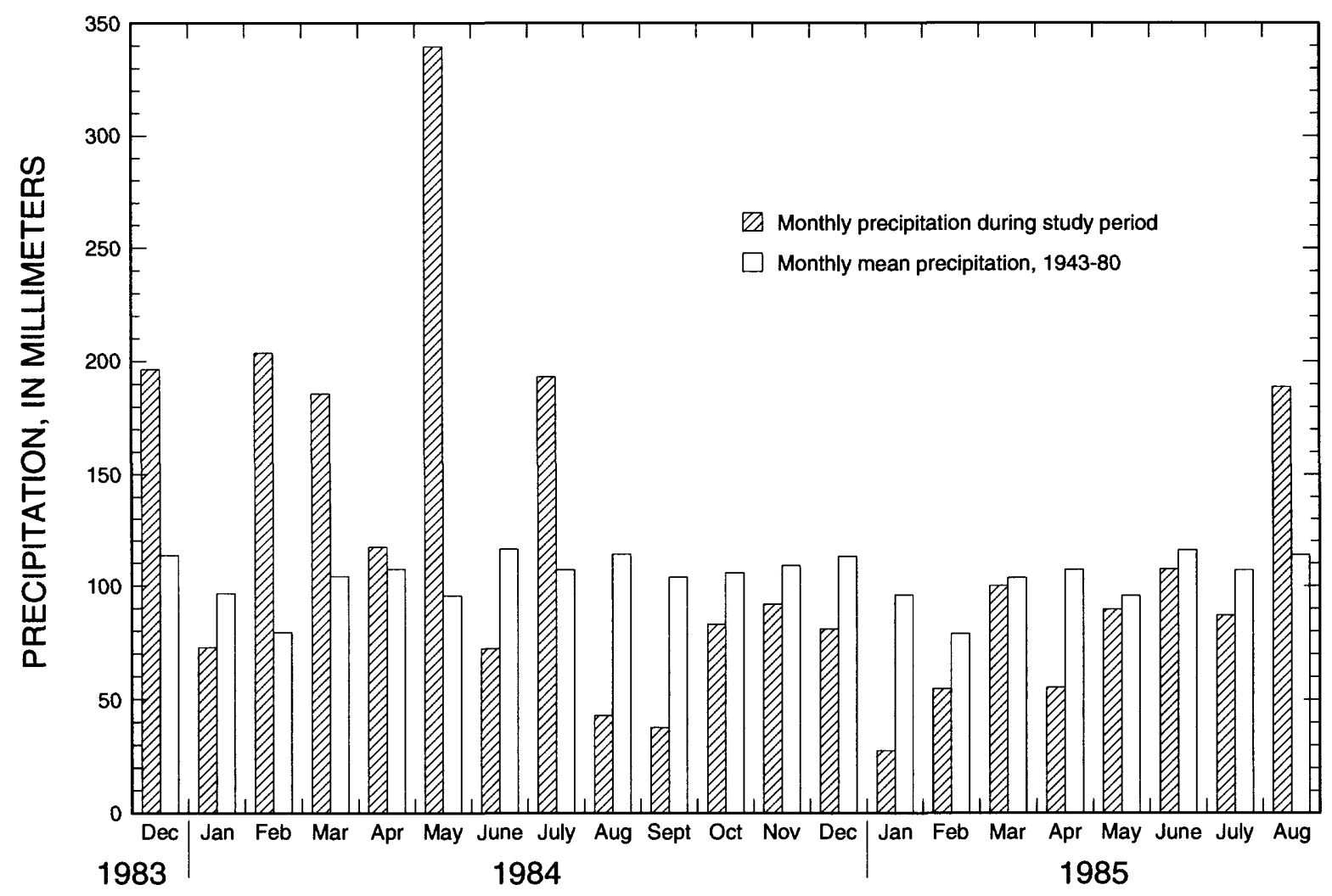

Figure 6. Mean monthly (1943-80) and monthly precipitation (November 1983 through August 1985) at New Salem, Massachusetts.

Table 1. Annual hydrologic budgets for West Branch Swift River and East Branch Fever Brook Basins, central Massachusetts

[All units in millimeters, except percentages. Water year 1984 (WY84) represents data collected from December 1983 through September 1984. Water year 1985 (WY85) represents data collected from October 1984 through August 1985. Total base flow determined by graphical techniques (Davis and DeWiest, 1966)]

\begin{tabular}{|c|c|c|c|c|c|}
\hline $\begin{array}{l}\text { Water } \\
\text { year }\end{array}$ & Precipitation & $\begin{array}{l}\text { Total } \\
\text { runoff }\end{array}$ & $\begin{array}{c}\text { Total } \\
\text { base flow }\end{array}$ & $\begin{array}{c}\text { Percentage of } \\
\text { precipitation as runoff }\end{array}$ & $\begin{array}{c}\text { Percentage of runoff } \\
\text { as base flow }\end{array}$ \\
\hline \multicolumn{6}{|c|}{ WEST BRANCH SWIFT RIVER BASIN } \\
\hline WY84 ...................... & .. $\quad 1,546$ & 915 & 464 & 59.2 & 50.7 \\
\hline WY85 ..................... & 969 & 285 & 174 & 29.4 & 61.1 \\
\hline \multicolumn{6}{|c|}{ EAST BRANCH FEVER BROOK BASIN } \\
\hline WY84 ..................... & .. $\quad 1,546$ & 744 & 290 & 48.1 & 39.1 \\
\hline WY85 ...................... & 969 & 290 & 145 & 29.9 & 50.0 \\
\hline Total .................... & .. $\quad 2,515$ & 1,034 & 435 & 41.1 & 42.1 \\
\hline
\end{tabular}




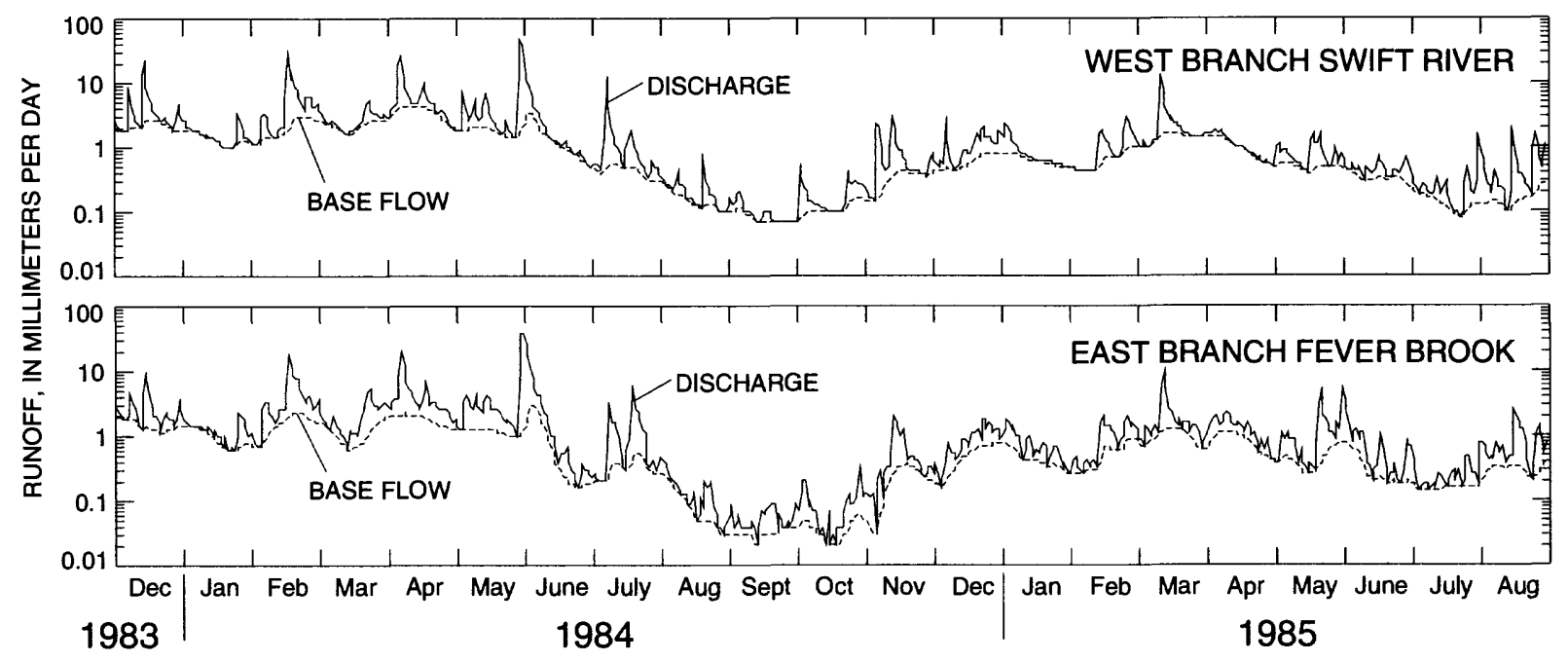

Figure 7. Temporal variation of discharge and base flow, West Branch Swift River and East Branch Fever Brook, central Massachusetts, December 1983 to September 1985.

and seasonally low evapotranspiration rates. Discharge peaks and total flow were lower in winter, spring, and early summer 1985 relative to the same period in 1984 .

Discharge at the outlet gaging stations in the Swift River and Fever Brook Basins responded rapidly to precipitation, as shown in the annual hydrographs (fig. 7). The magnitude of the hydrologic response generally was greater at Swift River than at Fever Brook. Particularly during the high-discharge period early in 1984 , peak daily flows (normalized to basin area as millimeters per day) associated with storms or snowmelt were higher at Swift River than at Fever Brook. The initial hydrograph recession was more rapid at Swift River than at Fever Brook, but the rate of recession slowed more quickly at Swift River, so that higher discharges were maintained several days after a storm or melt period. For example, peak daily discharges from a large storm in late May 1984 were $45 \mathrm{~mm}$ at Swift River and $40 \mathrm{~mm}$ at Fever Brook. Discharge decreased to less than $10 \mathrm{~mm}$ on the fourth day after peak discharge at Swift River, and not until the fifth day after peak discharge at Fever Brook. However, discharge decreased to $1 \mathrm{~mm}$ on the 13th day at Fever Brook and not until the 18th day at Swift River. Thus, there is a quick runoff component to flow at Swift River that is absent at Fever Brook, but subsurface storage also is sufficient in the Swift River Basin to sustain a long base-flow recession.

\section{Ground-Water Discharge}

The contrasting pattern of hydrograph recession in the two basins is attributed to greater subsurface storage capacity at Swift River and greater surface storage capacity at Fever Brook. At Swift River, a greater amount of storm and snowmelt waters infiltrate to recharge ground water, and the remaining runoff waters leave the basin relatively rapidly. At Fever Brook, the extensive areas of wetlands and impoundments attenuate and prolong the discharge peak, but flow decreases rapidly after the surface storage is depleted. The sustained higher rate of hydrograph recession at Fever Brook than at Swift River results in lower discharges when several days elapse without subsequent hydrologic inputs. Moreover, Fever Brook attained much lower minimum discharge levels during the summer low-flow period; the minimum daily discharge during the period of record was $0.02 \mathrm{~mm}$ at Fever Brook compared to $0.07 \mathrm{~mm}$ at Swift River (fig. 7). Lower minimum flows at Fever Brook relative to Swift River resulted in part from the higher evaporation caused by more exposed saturated areas. However, minimum flows also were lower at Fever Brook during the winter months, when evapotranspiration was negligible. This is indicative of a lower overall base-flow component at Fever Brook relative to that at Swift River.

The hydrograph separation verified the relatively greater importance of ground-water discharge (base flow) at Swift River. From December 1983 through September 1984, base flow was 51 and 39 percent of 
total runoff for Swift River and Fever Brook, respectively, and from October 1984 through August 1985 base flow was 61 and 50 percent of total runoff in the two streams (table 1). The relative percentage of base flow in each basin increased during water year 1985 because precipitation was much lower; a greater percentage of precipitation (snowmelt and rainfall) infiltrated to satisfy soil-moisture deficits, minimizing total runoff as streamflow. Although the flashier response of Swift River would be expected to result in a lower percentage of base-flow contribution, the impoundments in Fever Brook caused higher evapotranspiration of potential base-flow waters, and favored direct stormflow runoff by providing an extensive saturated contributing area.

\section{Evapotranspiration}

The importance of evapotranspiration at Fever Brook is illustrated by a comparison of runoff. In water year 1985, when precipitation was less than average, the two basins had nearly identical runoff (table 1). In water year 1984, when precipitation was greater than average, runoff was substantially lower at Fever Brook than at Swift River. Viewed in another way, the absolute amount of evapotranspiration (calculated as the difference between precipitation and runoff, that is, assuming no change in storage) at Swift River was nearly the same in each water year. This implies that water is apportioned first to evapotranspiration demand, and that only the excess appears as runoff. At Fever Brook, the absolute evapotranspiration was more than $100 \mathrm{~mm}$ greater in the wetter water year 1984. Because the vegetative demand for water probably was about the same in each basin for each water year, the increased evapotranspiration at Fever Brook in water year 1984 was attributed to increased evaporation from the greater area of open surface water in the wetter conditions of water year 1984. Records from two nearby streams, East Branch Swift River near Hardwick and Cadwell Creek near Belchertown (Gadoury and others, 1984, 1985) indicate that water years 1982 and 1983 had greater than average discharge. These data discount the possibility that the low runoff at Fever Brook in water year 1984 resulted from increased storage.

\section{CHEMICAL QUALITY OF PRECIPITATION, STREAMS, GROUND WATER, AND SOIL WATER}

\section{Precipitation Quality}

Hydrogen ion was the dominant cation in precipitation, contributing 75 percent of total cation charge (table 2). The volume-weighted average pH (determined from hydrogen ion equivalents) was 4.23 for December 1983 through August 1985. Volumeweighted concentrations of hydrogen ion, sulfate, and nitrate averaged approximately two times higher in the dry water year 1985 (October 1984 through August 1985) than in the wet water year 1984 (December 1983 through September 1984). Concentrations of base cations and chloride were about the same each year.

The concentration of hydrogen ion in wet deposition at New Salem was directly proportional to the concentration of sulfate, and to the sum of concentrations of sulfate and nitrate (fig. 8). Similar relations of hydrogen ion concentration with sulfate and nitrate concentrations have been observed in other studies of chemical

Table 2. Volume-weighted-average concentrations of solutes in wet deposition, New Salem, Massachusetts

[Concentrations are given in microequivalents per liter, except for precipitation (millimeters) and $\mathrm{pH}$ (standard units). To compute averages, concentrations less than detection limit were assigned a value of one-half the detection limit. Water year 1984 (WY84) represents data collected from December 1983 through September 1984. Water year 1985 (WY85) represents data collected from October 1984 through August 1985]

\begin{tabular}{|c|c|c|c|}
\hline \multirow[b]{2}{*}{$\begin{array}{l}\text { Solute or } \\
\text { property }\end{array}$} & \multicolumn{3}{|c|}{ Concentrations } \\
\hline & WY 84 & WY 85 & $\begin{array}{l}\text { Average dur- } \\
\text { ing period of } \\
\text { record }\end{array}$ \\
\hline $\begin{array}{l}\text { Hydrogen ion .......... } \\
\text { (pH) }\end{array}$ & $\begin{array}{l}39 \\
(4.41)\end{array}$ & $\begin{array}{l}88 \\
(4.05)\end{array}$ & $\begin{array}{l}58 \\
(4.23)\end{array}$ \\
\hline 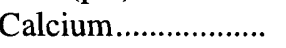 & 4.4 & 6.3 & 5.1 \\
\hline Magnesium .............. & 3.0 & 2.9 & 3.0 \\
\hline Sodium ............................ & 8.4 & 7.1 & 7.9 \\
\hline Potassium...................... & 1.0 & 1.3 & 1.1 \\
\hline Sulfate ........................... & 31 & 63 & 43 \\
\hline Nitrate & 17.6 & 38 & 25.5 \\
\hline Chloride ...................... & 7.4 & 7.2 & 7.3 \\
\hline \multicolumn{4}{|l|}{ Total } \\
\hline \multicolumn{2}{|c|}{ precipitation......1,546 } & 969 & 2,515 \\
\hline
\end{tabular}



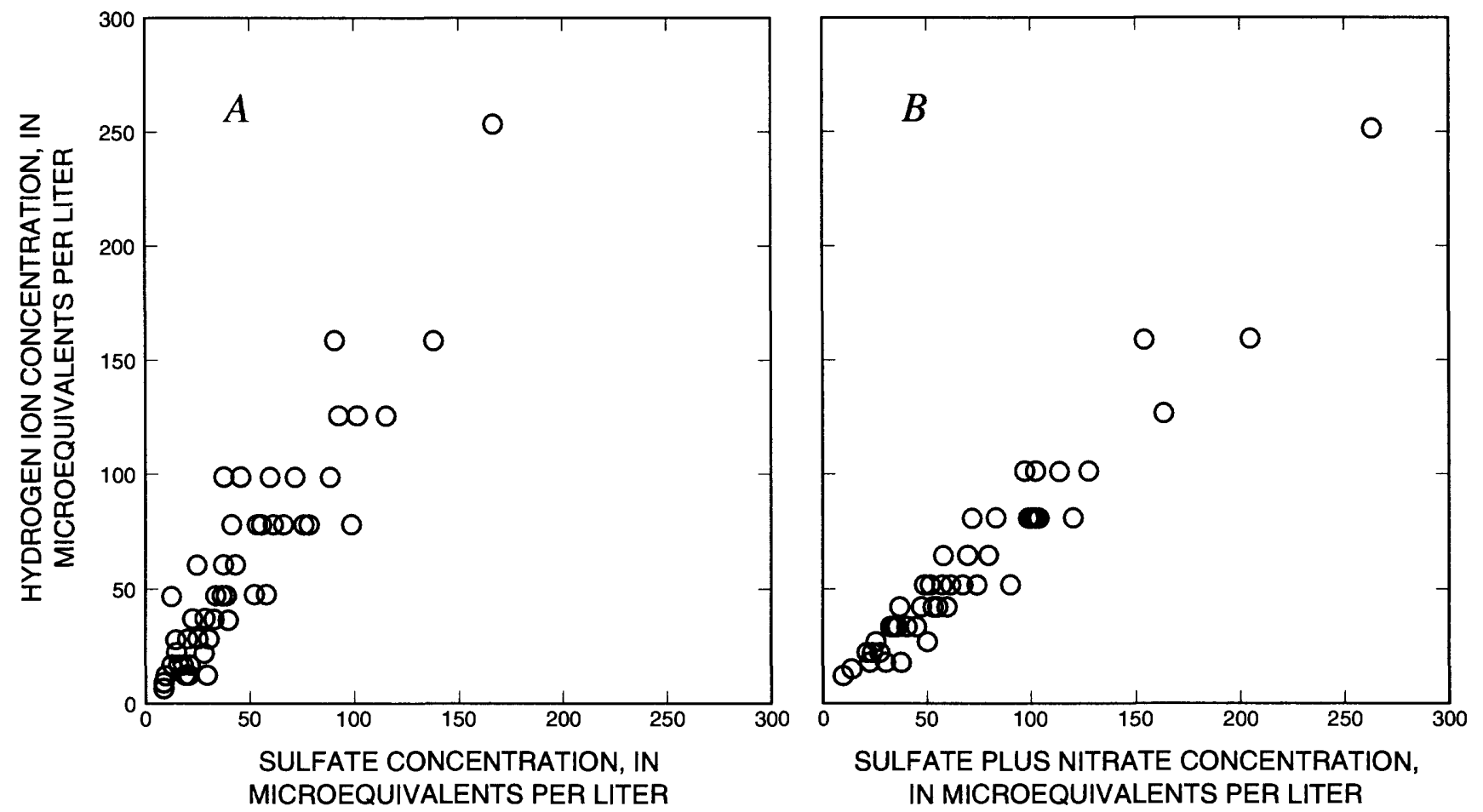

Figure 8. Relations between hydrogen ion concentration and sulfate concentration ( $A$ ), and hydrogen ion concentration and sulfate plus nitrate concentration $(B)$ in wet deposition, New Salem, Massachusetts.

composition of precipitation (Likens and others, 1979; Brezonik and others, 1980; Pack, 1980; Raynor and Hayes, 1982; Samson, 1987).

In precipitation collected at New Salem, the sum of volume-weighted-average concentrations of sulfate (43 $\mu \mathrm{eq} / \mathrm{L})$ and nitrate $(25.5 \mu \mathrm{eq} / \mathrm{L})$ exceeded the hydrogen ion input by only $10 \mu \mathrm{eq} / \mathrm{L}$. Based on the ratio of sulfate to nitrate and the approximate balance of these strong acid anions with the hydrogen ion concentration, nearly two-thirds of the acidity of the precipitation was sulfuric acid, and about one-third was nitric acid. Some of the sulfate and nitrate not associated with hydrogen ion may have been associated with ammonium $\left(\mathrm{NH}_{4}{ }^{+}\right)$. In the atmosphere, ammonia can neutralize nitrate and sulfate aerosols and form the ammonium salts $\mathrm{NH}_{4} \mathrm{HSO}_{4}$ and $\mathrm{NH}_{4} \mathrm{NO}_{3}$ (Monahan, 1984). This association also was observed by Munger and Eisenreich (1982), who found that the geographic distribution of ammonium deposition in the eastern United States was similar to that of sulfate and nitrate. The $\mathrm{pH}$ of pure water in equilibrium with atmospheric carbon dioxide gas at $25^{\circ} \mathrm{C}$ is 5.7 (Garrels and Christ, 1965). The pH of natural precipitation may differ from 5.7 because of reaction with dust derived from soil, marine aerosol, volcanic gases and ash, and other natural and anthropogenic gases and particulates (Gambell and Fisher, 1966; Likens and others, 1979; Raynor and Hayes, 1982). Precipitation $\mathrm{pH}$ lower than 5.0 generally is associated with anthropogenic sources of acidity (Schindler, 1988). Sulfur dioxide and nitrous oxide released as byproducts of fossil fuel burning (Monahan, 1984) are converted to sulfuric and nitric acid by atmospheric chemical reactions. Hydrochloric acid, generally a minor component of acid deposition, originates from industrial emission of chlorine gas (Gorham, 1976). Other sources of solutes in precipitation include sea-salt aerosols, soil dust, and fly-ash particles from industrial combustion processes. Assuming that natural rain water has a minimum $\mathrm{pH}$ of 5.0 $\left(10 \mu \mathrm{eq} / \mathrm{L} \mathrm{H}^{+}\right.$), at least 83 percent of the volumeweighted-average hydrogen ion concentration in wet deposition at New Salem (table 2) can be attributed to anthropogenic sources.

Variations of volume-weighted solute concentrations in wet deposition in water years 1984 and 1985 may be attributed to the differences in precipitation volumes and patterns during this period (table 2). 
Concentrations of base cations and chloride were very similar in the two water years, contrary to the expectation that concentrations would be lower during the much wetter year (water year 1984) from dilution. In contrast, concentrations of hydrogen, sulfate, and nitrate during water year 1984 were less than one-half those in water year 1985, resulting in considerably greater loads of these solutes in water year 1985 despite much less precipitation (see below). These patterns are consistent with a higher proportion of coastal storms in water year 1984 relative to water year 1985. Coastal storms are the primary source of precipitation during winter and early spring (Gambell and Fisher, 1966), thus greater amounts of the marine-derived solutes, such as magnesium, sodium, and chloride, were likely introduced by large storms during early 1984 . These same coastal storms also probably were dilute in the acidic components; sulfate, nitrate, and hydrogen ion. Risley and Shanley (1994) working at a site near Quabbin Reservoir, also noted that continental storms, which tracked over the industrialized midwestern United States, were relatively enriched in acidic components in comparison to coastal storms, which tracked up the Atlantic seaboard.

The volume-weighted mean $\mathrm{pH}(4.23$ as determined from $\mathrm{H}$ equivalents) in wet deposition for the study period was slightly higher than the $\mathrm{pH}$ recorded in 1982 at a nearby site at Fort River in central Massachusetts (Yuretich and Batchelder, 1988) and in the Adirondack Mountains in New York (Peters and others, 1982). However, the $\mathrm{pH}$ was somewhat lower than the $\mathrm{pH}$ recorded in 1982 and 1983 at Turners Falls, Massachusetts (Samson, 1987). Sulfate concentrations in wet deposition at New Salem were comparable to those at Turners Falls.

Volume-weighted mean concentrations of sulfate and hydrogen ion in wet deposition were significantly greater at New Salem than at Hubbard Brook in New Hampshire (Driscoll and others, 1989) during the study period. The time periods are not directly comparable because the Hubbard Brook data are reported for the calendar year. However, in 1984, precipitation at New Salem had a $\mathrm{pH}$ of 4.41 and a sulfate concentration of $31 \mu \mathrm{eq} / \mathrm{L}$, compared to corresponding values at Hubbard Brook of 4.47 and $25.5 \mu \mathrm{eq} / \mathrm{L}$. In 1985 , precipitation at New Salem had a pH of 4.05 and a sulfate concentration of $63 \mu \mathrm{eq} / \mathrm{L}$, compared to corresponding values at Hubbard Brook of 4.27 and $34.5 \mu \mathrm{eq} / \mathrm{L}$. Higher concentrations of these acidic components at New Salem may be a consequence of its location closer to industrial sources of anthropogenic acidity than was the case at Hubbard Brook. Concentrations of base cations in wet deposition at New Salem were nearly two times greater than those at Hubbard Brook during the two years. Base cations in precipitation counter the capacity of acidic deposition to consume alkalinity in surface waters (Driscoll and others, 1989).

Precipitation also was analyzed for trace elements. Concentrations of dissolved copper and lead in wet deposition were variable but generally less than $5 \mu \mathrm{g} / \mathrm{L}$. Based on analyses from water year 1984 only, concentrations of vanadium ranged from less than 1 to $5 \mu \mathrm{g} / \mathrm{L}$; concentrations of selenium and mercury generally were equal to or less than the detection limits of 1 and $0.1 \mu \mathrm{g} / \mathrm{L}$, respectively.

\section{Stream-Water Quality}

\section{Major-Ion Chemistry}

Flow-weighted-average concentrations were similar for many of the major dissolved chemical solutes in Swift River and Fever Brook during the study period (table 3). Each basin had low buffering capacity, with average alkalinity less than $30 \mu \mathrm{eq} / \mathrm{L}$. Hydrogen ion and nitrate averaged near $2 \mu \mathrm{eq} / \mathrm{L}$ in each basin, despite much higher concentrations in precipitation. Flowweighted average concentrations of sodium and chloride were higher at Fever Brook because of the higher amount of applied road salt in that basin.

Concentrations of most dissolved chemical solutes in the streams had pronounced temporal variations in response to storms and to seasonal changes (figs. 9 and 10). Alkalinity, silica, base cations, and chloride attained maximum concentrations during low flow in summer. At Fever Brook, concentrations of these solutes peaked later in the autumn, after the period of minimum discharges. Concentrations for these solutes reached a minimum during peak flows in spring. The $\mathrm{pH}$ and alkalinity reached minimum values during the May 1984 flood. The $\mathrm{pH}$ ranged from 5.1 to 6.8 at Swift River and from 5.4 to 6.3 at Fever Brook; alkalinity ranged from 1 to $136 \mu \mathrm{eq} / \mathrm{L}$ at Swift River and from 5 to $136 \mu \mathrm{eq} / \mathrm{L}$ at Fever Brook. 
Table 3. Flow-weighted-average concentrations of chemical solutes and runoff data, West Branch Swift River and East Branch Fever Brook, central Massachusetts

[Concentrations are given in microequivalents per liter unless otherwise noted. Water year 1984 (WY84) represents data collected from December 1983 through September 1984. Water year 1985 (WY85) represents data collected from October 1984 through August 1985. Average concentration during base-flow conditions: Base-flow samples taken from Rittmaster and Girouard (1992). $\mu \mathrm{mol} / \mathrm{L}$, micromole per liter; mm, millimeter. --, no data]

\begin{tabular}{|c|c|c|c|c|}
\hline \multirow{2}{*}{$\begin{array}{l}\text { Solute or } \\
\text { property }\end{array}$} & \multicolumn{4}{|c|}{ Concentrations } \\
\hline & WY84 & WY85 & $\begin{array}{l}\text { Average during } \\
\text { period of record }\end{array}$ & $\begin{array}{l}\text { Average during base- } \\
\text { flow conditions }\end{array}$ \\
\hline \multicolumn{5}{|c|}{ WEST BRANCH SWIFT RIVER (gaging station 01174565) } \\
\hline 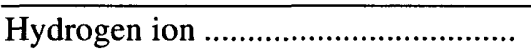 & 2.6 & 0.8 & 2.2 & 0.7 \\
\hline $\mathrm{pH}$ & 5.58 & 6.11 & 5.66 & 6.19 \\
\hline \multirow{2}{*}{ 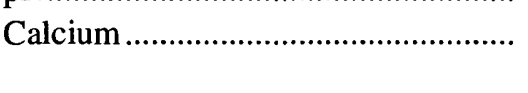 } & 108.1 & 117.4 & 110.3 & 104.0 \\
\hline & ${ }^{1} 104.0$ & ${ }^{1} 113.2$ & ${ }^{1} 106.2$ & -- \\
\hline \multirow[t]{2}{*}{ 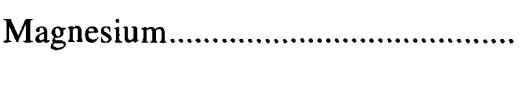 } & 37.0 & 39.9 & 37.7 & 40.0 \\
\hline & 136.5 & 139.4 & 137.2 & -- \\
\hline \multirow[t]{2}{*}{ Sodium } & 123.6 & 135.9 & 126.5 & 140.0 \\
\hline & 147.9 & 159.9 & ${ }^{1} 50.8$ & -- \\
\hline Potassium & 9.4 & 10.2 & 9.6 & 10.0 \\
\hline Alkalinity & 26.2 & 36.3 & 28.6 & 33.0 \\
\hline \multirow[t]{2}{*}{ Sulfate } & 139.9 & 147.9 & 141.8 & 150.0 \\
\hline & ${ }^{1} 138.5$ & ${ }^{1} 146.5$ & ${ }^{1} 140.4$ & -- \\
\hline 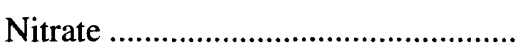 & 1.6 & 3.2 & 2.0 & -- \\
\hline \multirow[t]{2}{*}{ Chloride } & 91.5 & 103.8 & 94.4 & 99.0 \\
\hline & ${ }^{1} 12.5$ & 124.6 & ${ }^{1} 15.4$ & -- \\
\hline Silica $(\mu \mathrm{mol} / \mathrm{L}) \ldots$ & 102.9 & 112.1 & 105.1 & 102.0 \\
\hline Runoff (mm) & 915 & 285 & 1,200 & -- \\
\hline Base flow $^{2}(\mathrm{~mm}) \ldots \ldots \ldots$ & 464 & 174 & 638 & -- \\
\hline \multicolumn{5}{|c|}{ EAST BRANCH FEVER BROOK (gaging station 01174050) } \\
\hline 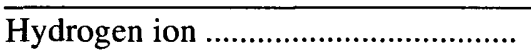 & 2.1 & 1.4 & 1.9 & 1.2 \\
\hline $\mathrm{pH}$ & 5.69 & 5.86 & 5.73 & 5.94 \\
\hline \multirow{2}{*}{ 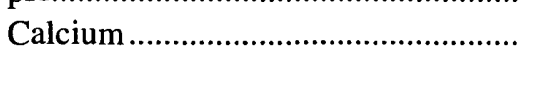 } & 97.2 & 123.7 & 104.6 & 120.0 \\
\hline & ${ }^{1} 68.5$ & ${ }^{1} 106.0$ & ${ }^{1} 79.0$ & -- \\
\hline \multirow[t]{2}{*}{ 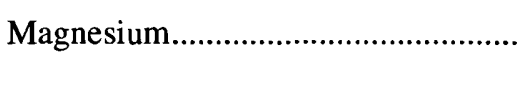 } & 50.9 & 66.0 & 55.1 & 60.0 \\
\hline & 138.4 & ${ }^{1} 59.7$ & 144.4 & -- \\
\hline \multirow[t]{2}{*}{ Sodium } & 206.4 & 256.7 & 220.5 & 270.0 \\
\hline & 142.5 & 138.1 & 141.3 & -- \\
\hline 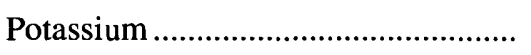 & 13.8 & 18.4 & 15.1 & 18.0 \\
\hline 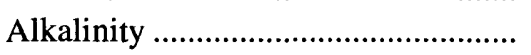 & 24.7 & 30.2 & 26.3 & 28.0 \\
\hline \multirow[t]{2}{*}{ Sulfate } & 132.8 & 131.9 & 132.6 & 146.0 \\
\hline & ${ }^{1} 129.3$ & ${ }^{1} 127.9$ & ${ }^{1} 128.9$ & -- \\
\hline 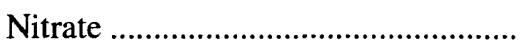 & 1.3 & 5.4 & 2.5 & -- \\
\hline \multirow[t]{2}{*}{ 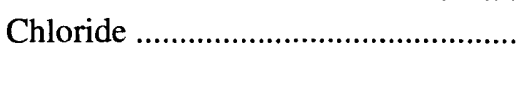 } & 221.3 & 258.6 & 231.8 & 235.0 \\
\hline & ${ }^{1} 15.4$ & ${ }^{1} 24.2$ & ${ }^{1} 17.8$ & -- \\
\hline Silica $(\mu \mathrm{mol} / \mathrm{L}) \ldots \ldots \ldots \ldots \ldots \ldots \ldots \ldots \ldots \ldots$ & 79.6 & 71.2 & 77.3 & 83.0 \\
\hline Runoff $(\mathrm{mm})$ & 744 & 290 & 1,034 & - \\
\hline Base flow ${ }^{2}(\mathrm{~mm}) \ldots \ldots \ldots$ & 290 & 145 & 435 & -- \\
\hline
\end{tabular}

'Concentration after deducting deicing-salt contributions (see section "Adjustment of Chemical Fluxes").

${ }^{2}$ Base flow determined by graphical techniques (Davis and DeWiest, 1966). 


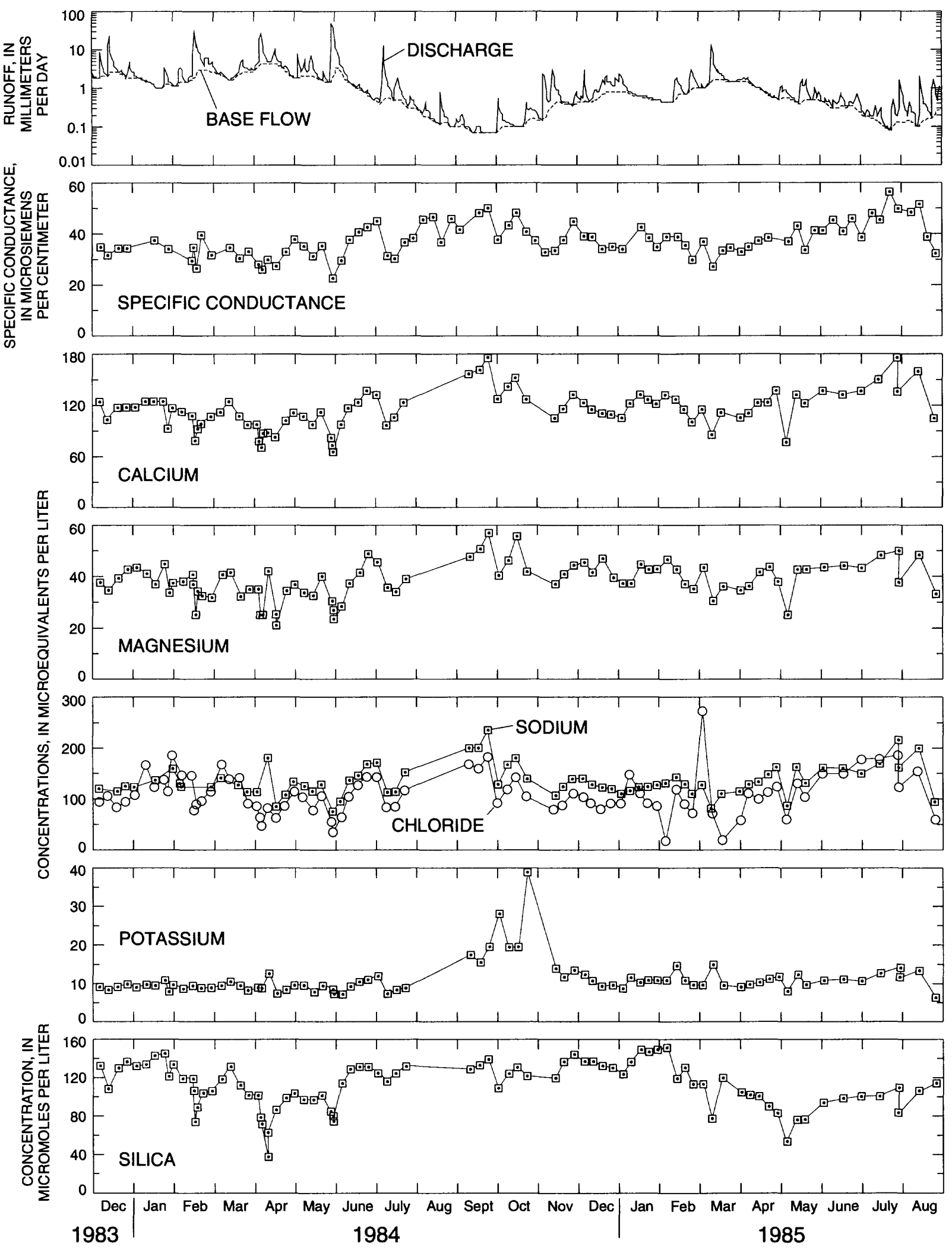

Figure 9. Temporal variation of runoff, specific conductance, and concentrations of selected chemical solutes, West Branch Swift River, central Massachusetts. 

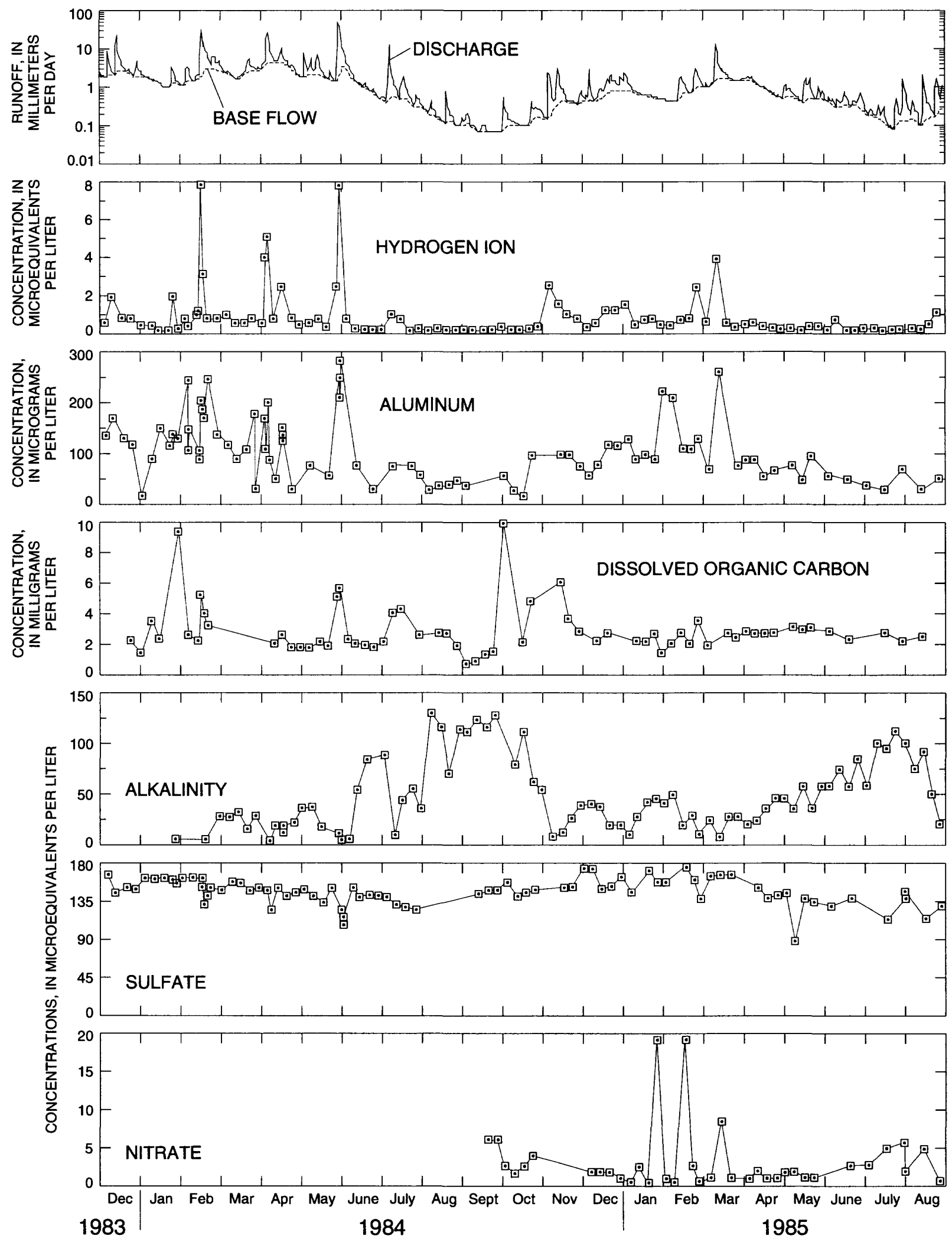

Figure 9. Temporal variation of runoff, specific conductance, and concentrations of selected chemical solutes, West Branch Swift River, central Massachusetts-Continued. 

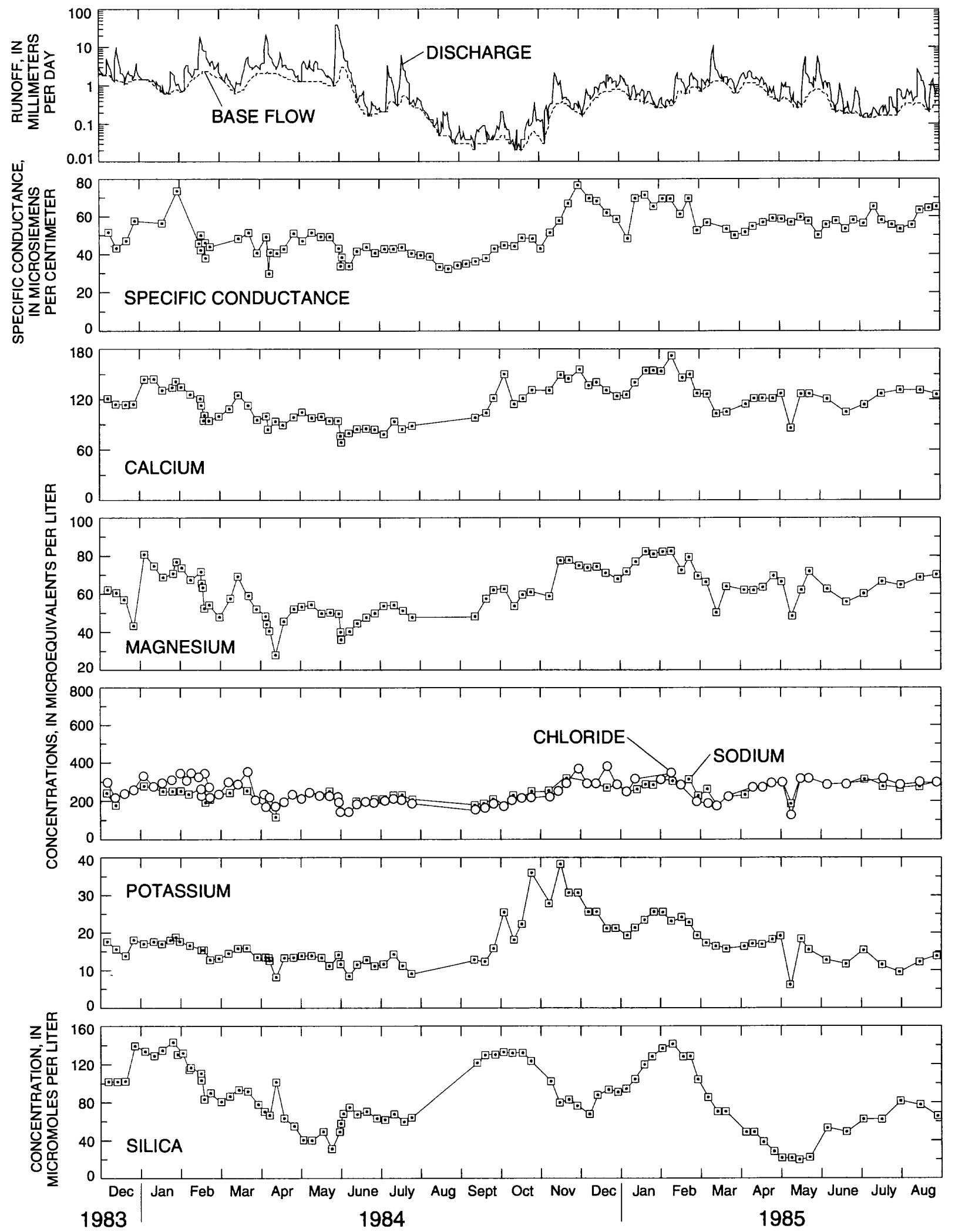

Figure 10. Temporal variation of runoff, specific conductance, and concentrations of selected chemical solutes, East Branch Fever Brook, central Massachusetts. 

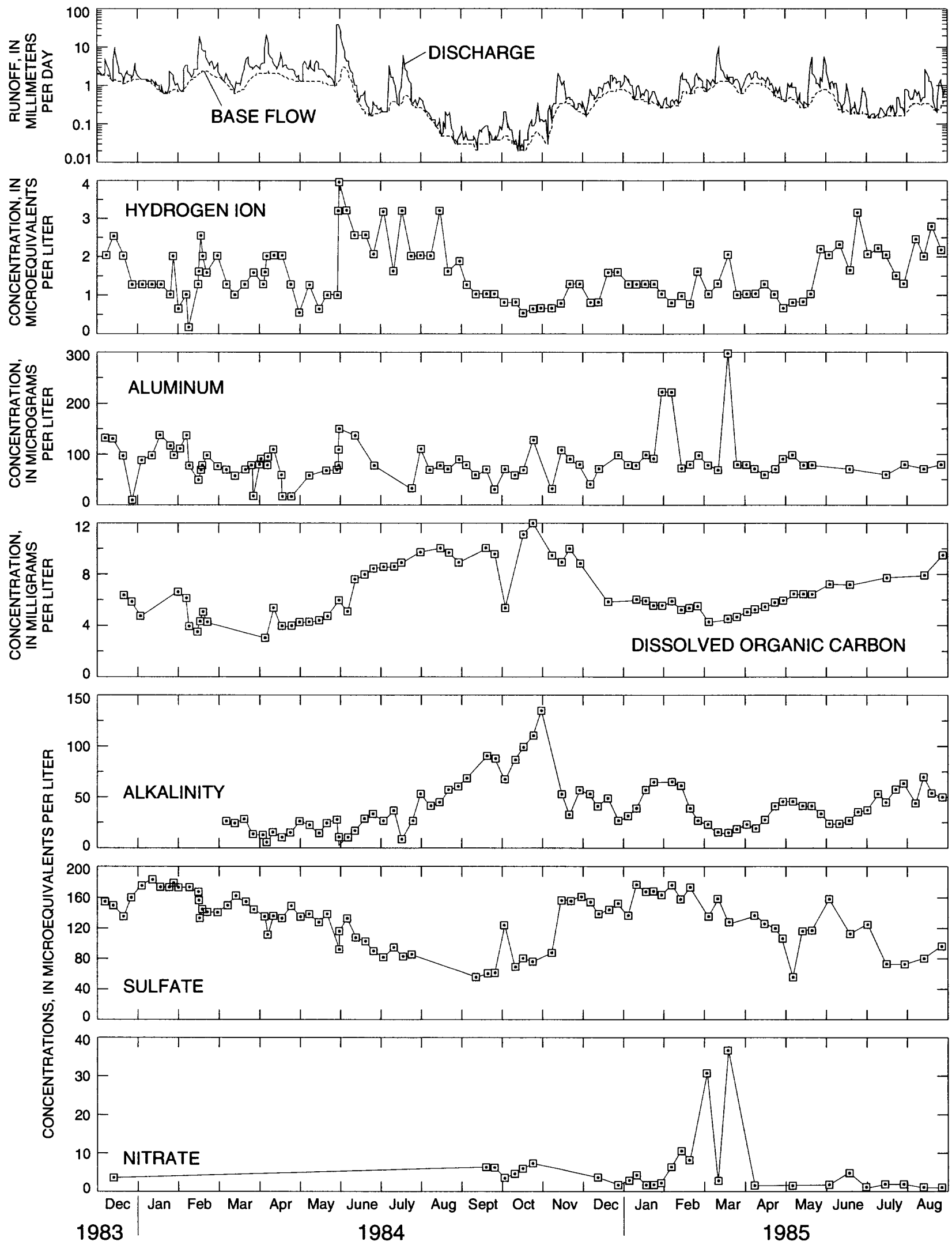

Figure 10. Temporal variation of runoff, specific conductance, and concentrations of selected chemical solutes, East Branch Fever Brook, central Massachusetts-Continued. 
The dilution of silica was much more significant at Fever Brook, suggesting the possibility of silica uptake by spring diatom blooms in the impoundments. Patterns of potassium concentrations were similar to those of the other base cations, with the exception that the maximum concentration in autumn was more pronounced, probably as a result of decomposing leaves. Concentrations of dissolved organic carbon (DOC) in Swift River increased markedly in association with snowmelt and rainfall runoff, and in autumn coincident with the peak in potassium. At Fever Brook, DOC progressively increased through the summer, probably as a result of decomposition of organic matter in the impoundments. Concentrations of DOC peaked at Fever Brook in autumn, also coincident with the peak in potassium concentration, suggesting that leaf decomposition further increased DOC concentrations.

Sulfate concentrations were higher and less variable at Swift River than at Fever Brook. At Fever Brook, sulfate decreased during low flow in summer and early autumn, whereas at Swift River there was no apparent change. Concentrations of nitrate in the streams generally were low compared to those in precipitation, but during snowmelt runoff in 1985, concentration of nitrate peaked at nearly $20 \mu \mathrm{eq} / \mathrm{L}$ in Swift River and exceeded $35 \mu \mathrm{eq} / \mathrm{L}$ in Fever Brook.

The effect of road deicing salts was evident in the high sodium and chloride concentrations in both basins, particularly in Fever Brook. Before adjustments for deicing salts, the total flow-weighted average base cation concentration was $284 \mu \mathrm{eq} / \mathrm{L}$ in Swift River and $396 \mu \mathrm{eq} / \mathrm{L}$ in Fever Brook; after adjustments, the concentrations were 204 and $180 \mu \mathrm{eq} / \mathrm{L}$, respectively (calculated from table 3 ). The distribution of adjusted cation concentrations was somewhat different in the two basins. Fever Brook had moderately higher potassium and magnesium concentrations than Swift River, whereas Swift River had higher sodium and calcium concentrations. When comparing the concentrations for the two water years at each site, Fever Brook had markedly higher concentrations of calcium and magnesium in water year 1985, the drier of the two years, whereas there was little difference in calcium and magnesium concentrations between the two water years at Swift River. Despite the similarity in base-cation concentrations, the average silica concentration was about 35 percent higher in the Swift River than in Fever Brook.
After adjustment for salt-derived chloride, sulfate was the dominant anion in each basin, $140.4 \mu \mathrm{eq} / \mathrm{L}$ at Swift River and near $128.9 \mu \mathrm{eq} / \mathrm{L}$ at Fever Brook. Sulfate accounted for nearly 75 percent of the anion charge. Bicarbonate, assumed equal to alkalinity, was the second most dominant anion. Background chloride concentrations, assumed to be derived only from the atmosphere, were about one-half the bicarbonate concentration in each basin; nitrate was a very minor component.

Stream water at headwater sites and tributaries in the two basins (figs. 4 and 5) generally was more dilute and more poorly buffered than stream water at the outlet gaging stations (table 4). In general, solute chemistry did not vary markedly among the tributary sites in each basin. An exception was site 01174564 (fig. 4), the tributary that drains the area of gabbro bedrock in the southeast part of the Swift River Basin. Mean $\mathrm{pH}$ at this tributary site was 6.88 compared to a $\mathrm{pH}$ range of 5.07 to 5.58 at the other Swift River Basin tributaries. Basecation concentrations at this tributary were higher by a factor of 3 , and alkalinity by a factor of 10 , relative to the other Swift River tributary sites.

Seasonal patterns of solute concentration variations at the tributary and headwater sites were similar to those at the outlets. Dissolved solute concentrations and $\mathrm{pH}$ generally increased during summer base-flow conditions in summer and autumn and decreased during high-flow conditions in spring (fig. 11). Although variations in solute concentration generally were similar among tributaries in each basin, consistent differences were apparent between the inlet and outlet of Brooks Pond, an impoundment on Fever Brook. Concentrations of calcium, alkalinity, and silica, as well as $\mathrm{pH}$, generally were greater at the site upstream of the pond (01174035) than at the site downstream of the pond (01174040) (fig. 5). The concentration difference was greatest in summer, particularly for silica, which reached a minimum concentration at the downstream site in summer (fig. 11).

\section{Aluminum Chemistry}

Concentration of aluminum at the Swift River and Fever Brook outlet gaging stations ranged from less than 10 to $280 \mu \mathrm{g} / \mathrm{L}$ (figs. 9 and 10). Concentrations of aluminum and hydrogen ion were highest during high flows in late winter and spring runoff. This pattern was contrary to most relations between dissolved solutes 


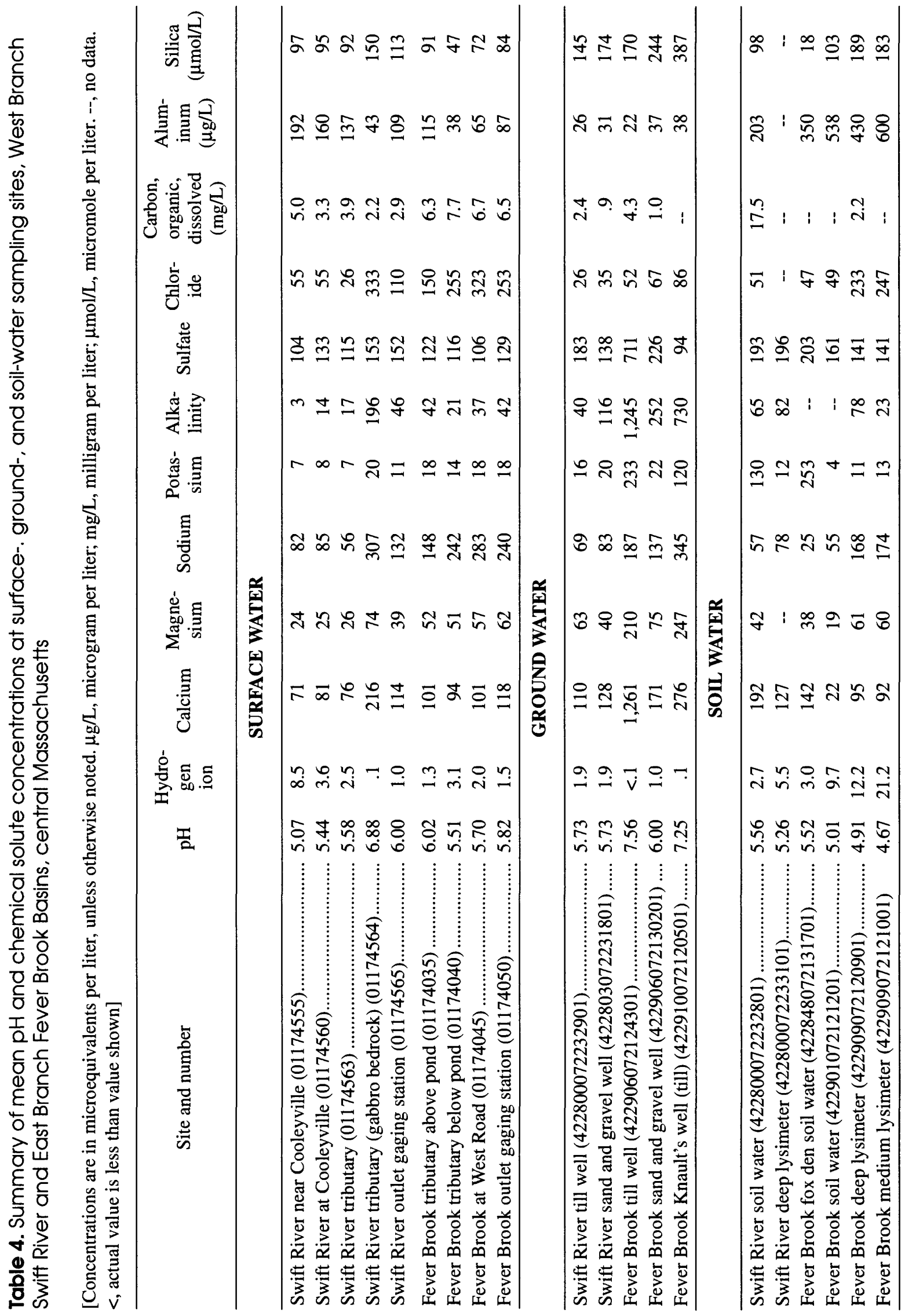



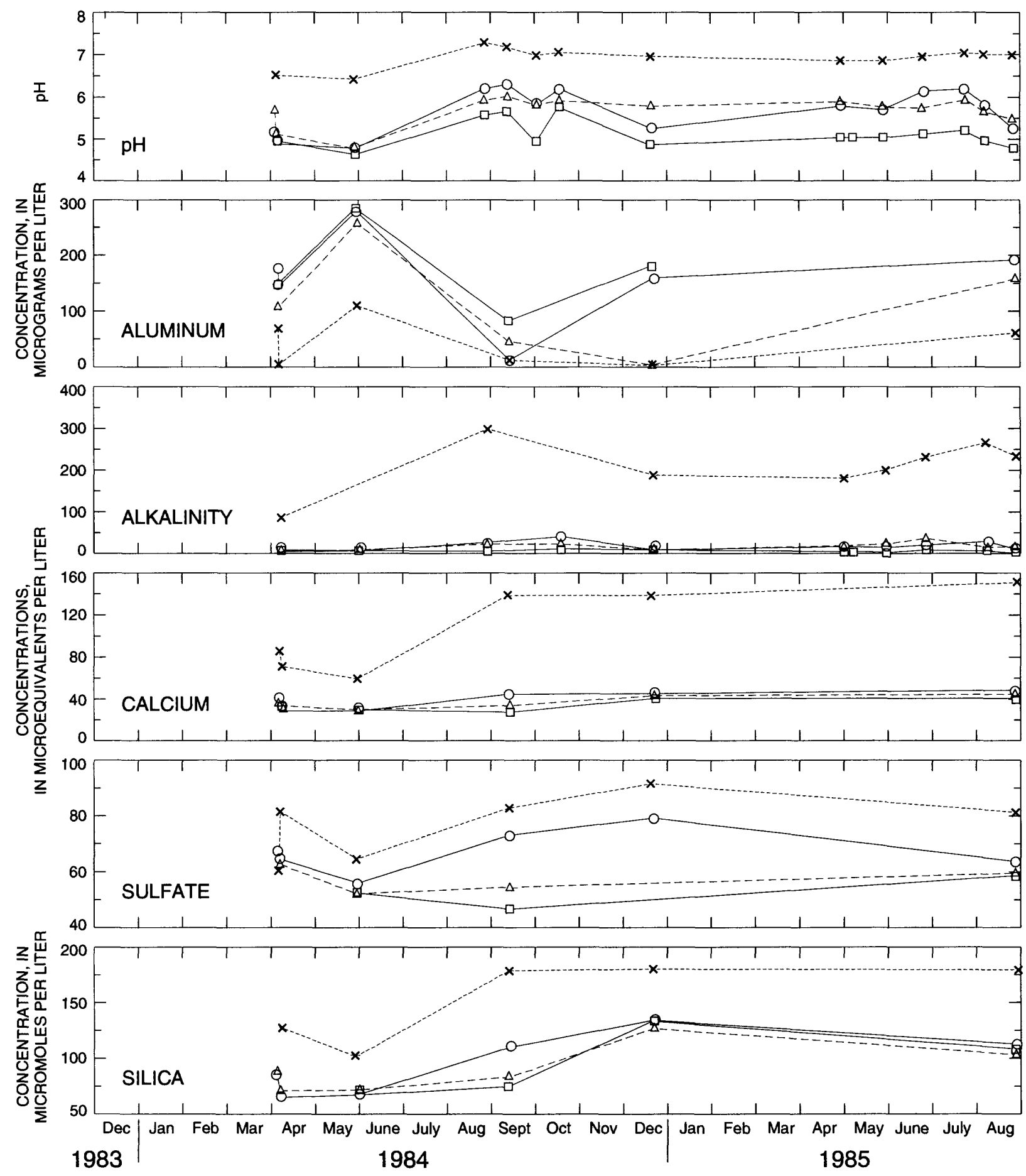

EXPLANATION

Swift River near Cooleyville (Station Number 01174555)
$-\ldots-$ Swift River at Cooleyville (Station Number 01174560)
$-\ldots \ldots$ Swift River tributary 1 (Station Number 01174563)

Figure 11. Temporal variation of $\mathrm{pH}$ and concentrations of selected chemical solutes, tributaries of West Branch Swift River $(A)$ and East Branch Fever Brook (B), central Massachusetts. 

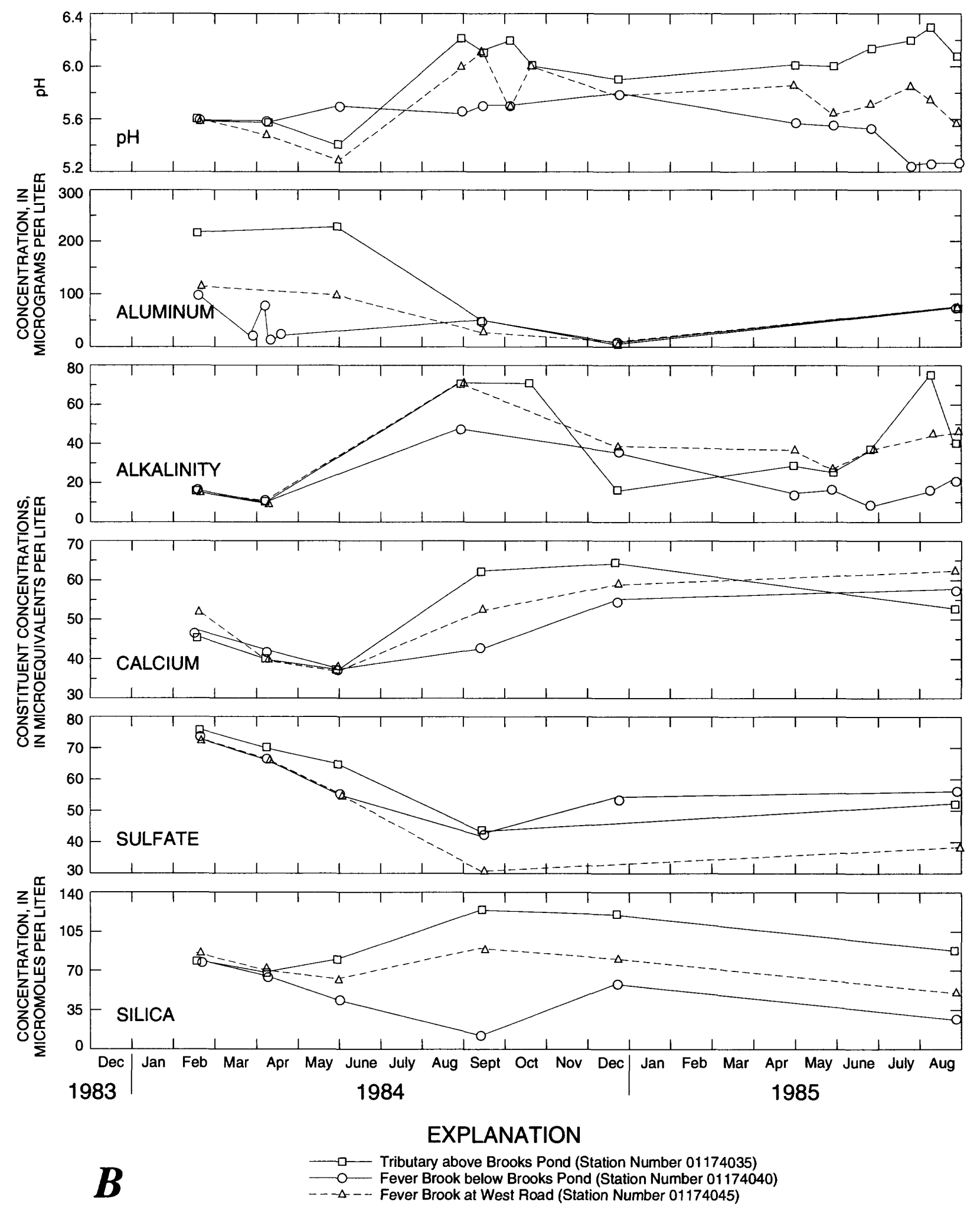

Figure 11. Temporal variation of $\mathrm{pH}$ and concentrations of selected chemical solutes, tributaries of West Branch Swift River $(A)$ and East Branch Fever Brook (B), central MassachusettsContinued. 
and discharge in which solute concentration decreased as discharge increased. Concentrations of aluminum and hydrogen ion clearly were affected by high-flow events. At Swift River, baseline concentrations of aluminum and hydrogen ion were somewhat lower than those at Fever Brook, but episodic increases in concentration were more frequent and greater in magnitude. Concentrations of dissolved aluminum peaked (greater than $250 \mu \mathrm{g} / \mathrm{L}$ ) during the May 1984 flood at Swift River and during early snowmelt periods at Fever Brook.

At Swift River, aluminum concentrations generally were less than $100 \mu \mathrm{eq} / \mathrm{L}$, but increased to near $300 \mu \mathrm{g} / \mathrm{L}$ in response to storm runoff and snowmelt in winter and spring (fig. 9). At Fever Brook, aluminum concentrations ranged from 0 to $150 \mu \mathrm{eq} / \mathrm{L}$, with less frequent increases to near $300 \mu \mathrm{g} / \mathrm{L}$; there was no distinctive seasonal pattern (fig. 10). Because aluminum concentration increases tend to be episodic, the weekly sampling in this study probably does not adequately describe the frequency and magnitude of the increases.
However, the apparent higher responsiveness of aluminum concentrations to increased flows at Swift River was consistent with the rapid hydrologic response of the stream; spikes in aluminum concentrations generally are associated with water that enters streams quickly along shallow flow paths (McAvoy, 1989).

High aluminum concentrations in surface water, ground water, and soil water in both basins generally were associated with low pH (fig. 12). This was particularly evident at tributary sites in the Swift River Basin. For example, after the 230-mm rainstorm in May 1984, $\mathrm{pH}$ at the headwater tributary sites ranged from 4.7 to 4.8 , and aluminum concentration ranged from 260 to $290 \mu \mathrm{g} / \mathrm{L}$ (fig. 11). In contrast, during the same period at the tributary draining the gabbro subcatchment, the $\mathrm{pH}$ was 6.5 and the aluminum concentration was $110 \mu \mathrm{g} / \mathrm{L}$.

Aluminum concentrations in tributary streams generally were greater at Swift River sites than at Fever Brook sites (table 4). However, aluminum concentrations were greater at Fever Brook sites during

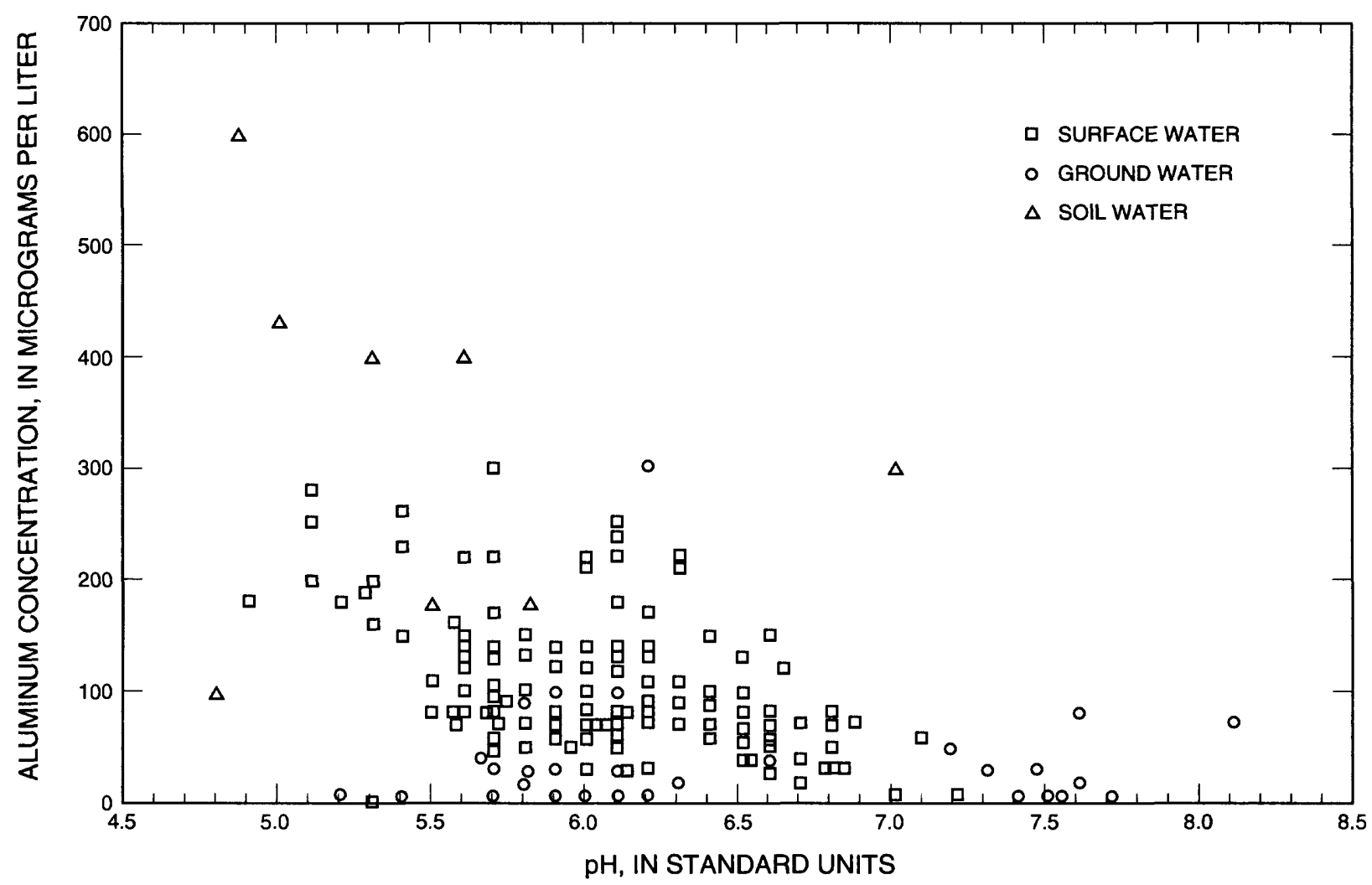

Figure 12. Relations between aluminum concentrations and $\mathrm{pH}$ in surface water, ground water, and soil water, West Branch Swift River and East Branch Fever Brook, central Massachusetts. 
summer low flow. Aluminum concentrations at the uppermost sites in both basins [01174555 in Swift River Basin (fig. 4) and 01174035 in Fever Brook Basin (fig. 5)] were greater than at downstream sites during most sampling periods. At Fever Brook, aluminum concentrations varied considerably but generally were uniformly less than $50 \mu \mathrm{eq} / \mathrm{L}$ throughout the basin during base flow. Concentrations of aluminum at Swift River Basin tributary sites ranged from less than 10 to $290 \mu \mathrm{g} / \mathrm{L}$. At Swift River tributary sites 01174560 and 01174563 , aluminum concentrations were relatively constant near $150 \mu \mathrm{g} / \mathrm{L}$. At site 01174564 , the tributary that drains the gabbro area, aluminum concentrations were significantly lower.

\section{Trace Elements}

In general, total and dissolved concentrations of the trace elements copper, lead, arsenic, selenium, and mercury in stream samples were less than standards outlined by the U.S. Environmental Protection Agency (1986) for domestic, aquatic, and irrigation use. Total and dissolved concentrations of copper ranged from 0.2 to $13 \mu \mathrm{g} / \mathrm{L}$. Total and dissolved concentrations of lead ranged from 0.1 to $13 \mu \mathrm{g} / \mathrm{L}$, but the concentrations generally were less than $2 \mu \mathrm{g} / \mathrm{L}$, much less than the domestic use standard of $50 \mu \mathrm{g} / \mathrm{L}$. Maximum concentrations of arsenic and selenium were $1 \mu \mathrm{g} / \mathrm{L}$, which is the analytical detection limit. Maximum concentration of mercury was $0.9 \mu \mathrm{g} / \mathrm{L}$, but concentrations of most samples were less than $0.1 \mu \mathrm{g} / \mathrm{L}$, the analytical detection limit.

\section{Ground-Water and Soil-Water Quality}

At the two Swift River wells, ground water was relatively poorly buffered as indicated by the relative low pH's (table 4). Although silica concentrations were somewhat elevated, alkalinity and base-cation concentrations were in the same range as surface waters. In ground water at Fever Brook, however, concentrations of nearly all solutes were elevated relative to surface water. Ground water from the Fever Brook till well, in particular, had alkalinity and calcium concentrations greater than $1,000 \mu \mathrm{eq} / \mathrm{L}$. Coupled with the relatively low silica concentration, the chemistry at this well is suggestive of carbonate weathering, though no carbonates have been found in the region. This well also had unusually high sulfate concentrations, indicative of sulfide weathering. In contrast, ground water at the other till well at Fever Brook (Knault's well) is silica- rich and sulfate-poor. Water at this well is high in alkalinity and base cations and the chemical composition seems to be controlled by silicate weathering. The high solute concentrations in these waters indicates that only a small amount of this water type may contribute to streamflow. Ground-water chemistry at the sand and gravel well at Fever Brook is similar to that at the Swift River wells, although somewhat more enriched in silica, alkalinity, and base cations, which are probable weathering products.

Soil waters in both basins were poorly buffered, low-pH waters enriched in aluminum (table 4). In general, these waters reflect incipient contact of acidic precipitation with the surficial soil; sulfate concentrations were nearly equal to or somewhat higher than those in precipitation; varying amounts of silica were derived from soil contact; and aluminum and DOC were derived most likely from the forest floor. Alkalinities were comparable to those in surface water, despite the low $\mathrm{pH}$ and high aluminum concentrations. This is attributed to the presence of organics. In the normal course of chemical evolution of soil water to ground or surface water, the organic matter will oxidize, causing an increase in alkalinity and a decrease in aluminum.

\section{CHEMICAL FLUXES ENTERING AND LEAVING STREAM BASINS}

\section{Chemical Input Loads in Precipitation}

Loads of hydrogen ion, sulfate, and nitrate were greater in water year 1985 than in water year 1984, despite the much lower precipitation in water year 1985 (table 5). Loading of base cations and chloride was greater in the wetter year because concentrations of these solutes vary little with precipitation amount. Occasionally, particularly when precipitation volume was high, solute concentrations in weekly samples were less than the detection limit of the analytical method. In these cases, solute concentrations were assumed to be one-half the detection limit. If this assumption is in error, the total input fluxes of chloride may be in error by a maximum of 48 percent for sodium, 10 percent for chloride, and 5 percent for nitrate. Other solutes are relatively unaffected by an error in the assumption.

Loadings of hydrogen ion and sulfate in wetdeposition samples at New Salem generally were greater during the summer and early autumn compared 


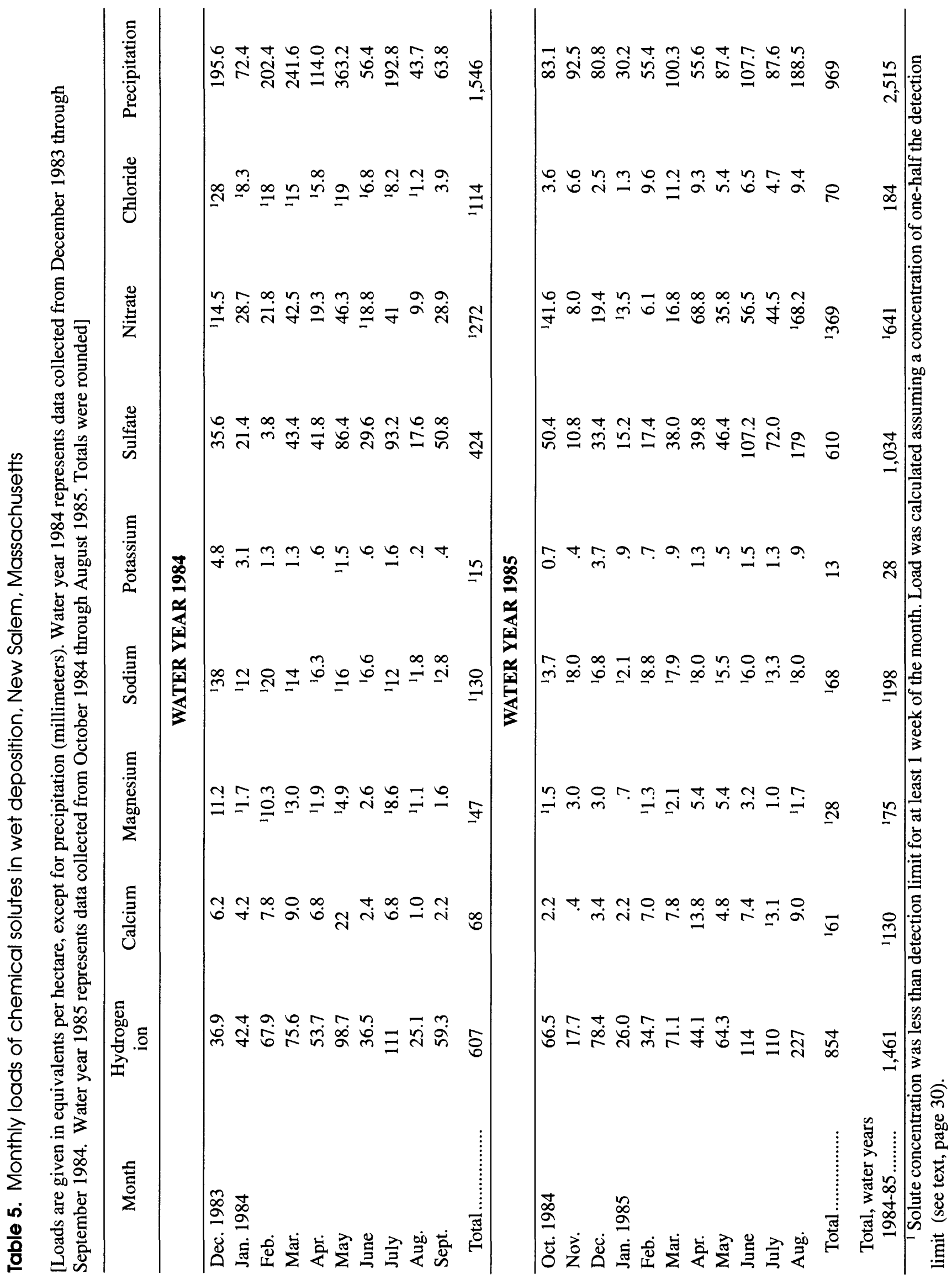


to other seasons (table 5). The seasonal pattern of maximum loading in summer and minimum loading in winter for hydrogen ion and sulfate in precipitation is common (Likens and others, 1979; Raynor and Hayes, 1982; Suarez and Jones, 1982), and is attributed to annual cycles of wind direction and air mass velocity. The concentration/volume relation, in which high solute concentrations are associated with low precipitation volume (Raynor and Hayes, 1982), causes deviations from this annual cycle. For example, two low-volume wet-deposition samples from early April 1985 had hydrogen ion concentrations among the highest measured during the study. Loadings of acidic and basic components in wet deposition at New Salem probably have decreased in recent years, based on decreasing trends at Hubbard Brook (Driscoll and others, 1989) and on the recent decline in emissions of sulfur dioxide in the northeastern United States (Smith and Alexander, 1983).

\section{Chemical Output Loads in Streamflow}

\section{Concentration-Discharge Relations}

As the first step in the output flux calculations, the concentration-discharge models described in the "Methods of Study" section were applied for all major solutes analyzed in each basin (table 6). For nearly all constituents, coefficients of determination $\left(r^{2}\right)$ were greater at Swift River compared to those at Fever Brook. Based on a minimum acceptable $r^{2}$ of 0.40 , models could be used to calculate concentration from discharge for hydrogen ion, magnesium, sodium, potassium, and alkalinity at Swift River, but could be used only for alkalinity at Fever Brook. Concentrations of major cations at Fever Brook, and concentrations of all anions except bicarbonate at both sites, correlated poorly with discharge.

The concentration/discharge regression analysis was done prior to any adjustment of concentrations or loads for deicing salts. Salts enter the ground-water system and are released throughout the year, thus it is possible to have a significant correlation between discharge and base-cation concentrations throughout the year, despite the fact that deicing salt is applied only in winter. However, the generally poor correlations at Fever Brook may be related to the relatively greater effect of deicing salts in that basin.
At Swift River, concentrations of solutes derived primarily from weathering and ion exchange (base cations, alkalinity, and silica) were inversely related to discharge; that is, concentrations were at a maximum during low flow and at a minimum during high flow (fig. 13). For example, calcium concentration had a highly significant inverse relation to log discharge. In contrast, concentrations of sulfate, nitrate, and chloride, which were controlled by loadings in atmospheric deposition and deicing salts, were weakly correlated with discharge. There was a significant inverse relation between $\mathrm{pH}$ and discharge at Swift River. Likewise, alkalinity varied inversely with discharge. Sulfate concentrations were relatively constant; there was little relation of sulfate concentration with flow except for a slight dilution at high flows.

At Fever Brook, alkalinity was the only solute that was significantly correlated with discharge $\left(r^{2}=0.69\right)$. Although alkalinity generally is regarded as a weathering product, the lack of significant concentrationdischarge relations for the other solutes indicates that the significant relation for alkalinity was related to some process other than weathering, most likely biologic production of alkalinity in impoundments. Alkalinity increased during summer and autumn as flow decreased and biological activity increased. Other solutes correlated with discharge in different parts of the flow regime at Fever Brook. Calcium correlated inversely with discharge at high discharge. Sulfate increased with discharge at low discharges but there was no relation at moderate or high discharge.

\section{Monthly Solute Fluxes in Streamflow}

Monthly stream loads were calculated for December 1983 through August 1985 (table 7) using either the linear regression models or the time-series method. Variation in monthly load of each major chemical solute analyzed was at least ten-fold. In general, these variations were associated with a similar magnitude of change in monthly runoff, an indication that monthly loads were primarily a function of monthly runoff.

\section{Net Solute Fluxes}

Net fluxes of major solutes in the two drainage basins were calculated for the study period (table 8 ). Uptake of hydrogen and nitrate in the two drainage basins was significant, as indicated by the large positive 


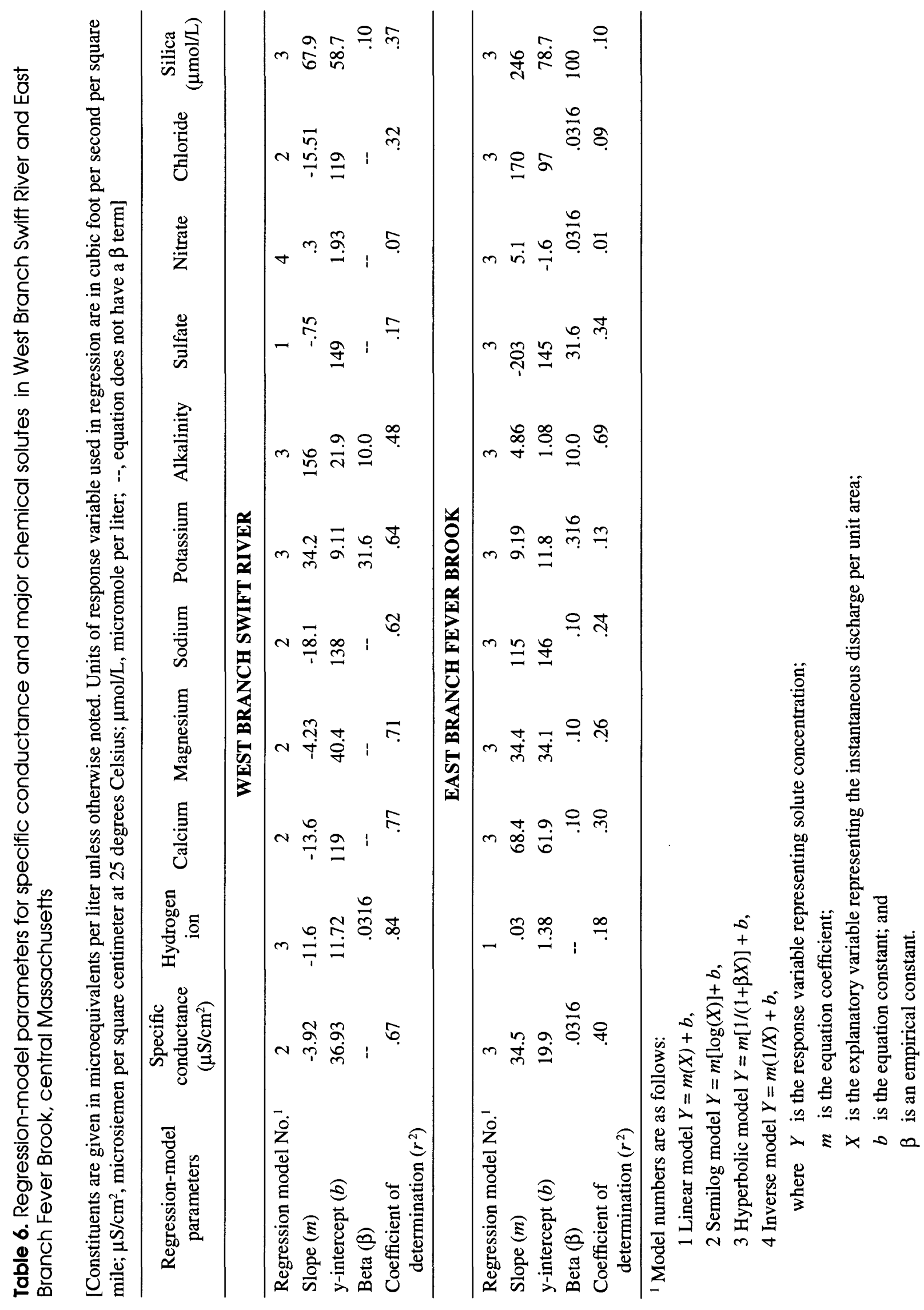



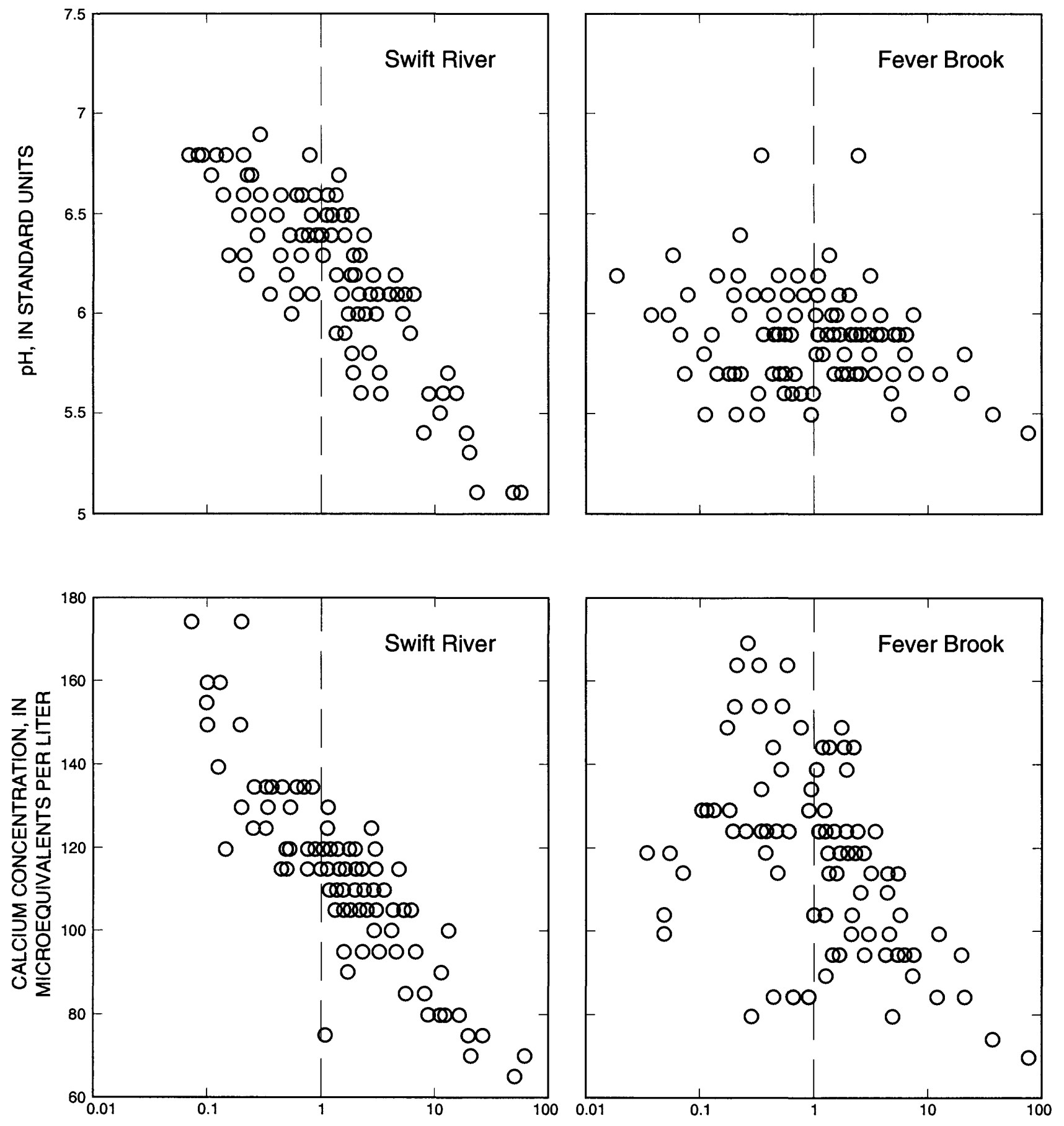

DISCHARGE, IN CUBIC FEET PER SECOND PER SQUARE MILE

Figure 13. Relations between discharge and $\mathrm{pH}$, calcium, alkalinity, and sulfate at Swiff kIver and Fever Brook, central Massachusetts. 

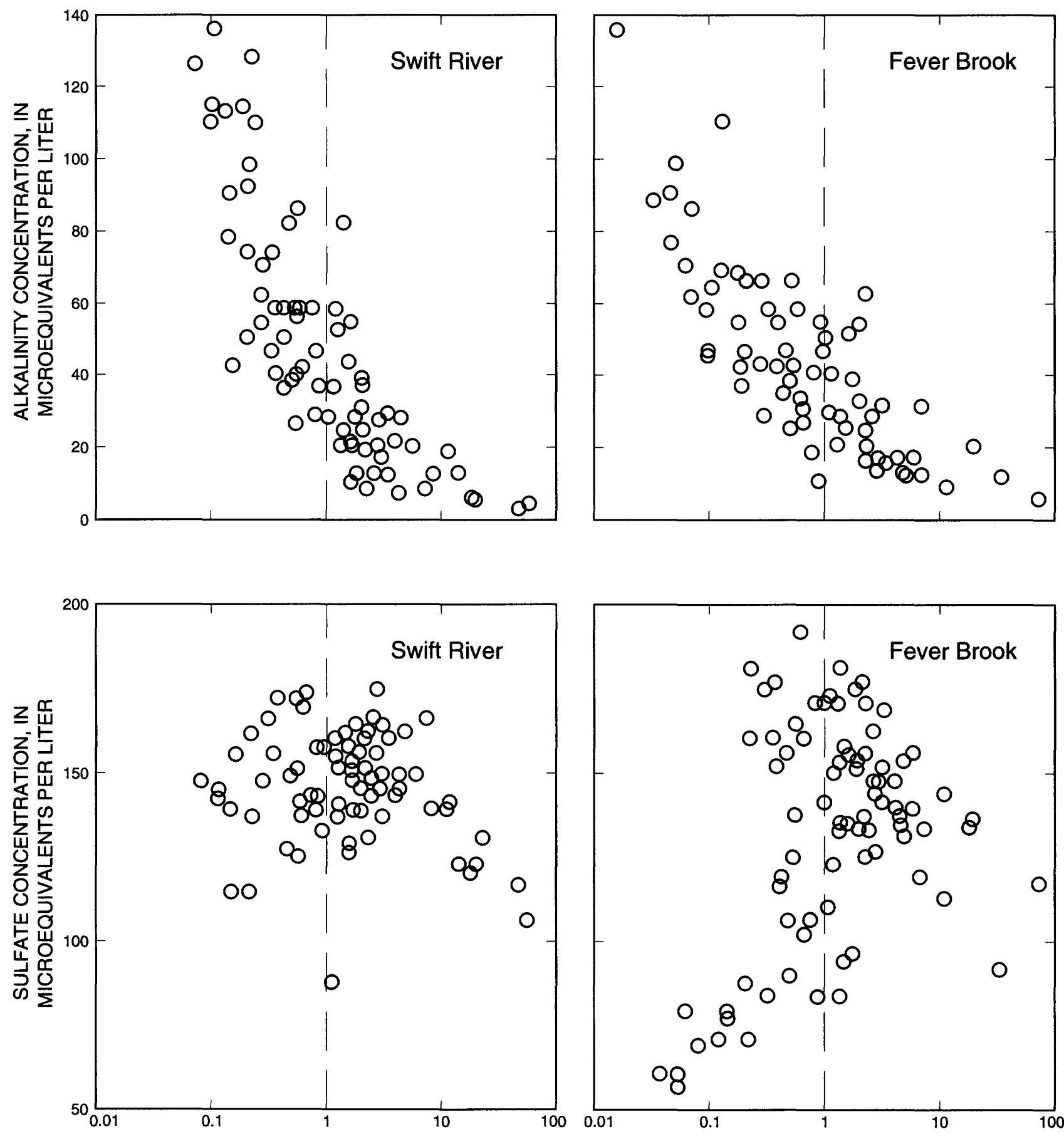

DISCHARGE, IN CUBIC FEET PER SECOND PER SQUARE MILE

Figure 13. Relations between discharge and $\mathrm{pH}$, calcium, alkalinity, and sulfate at Swift River and Fever Brook, central Massachusetts-Continued. 


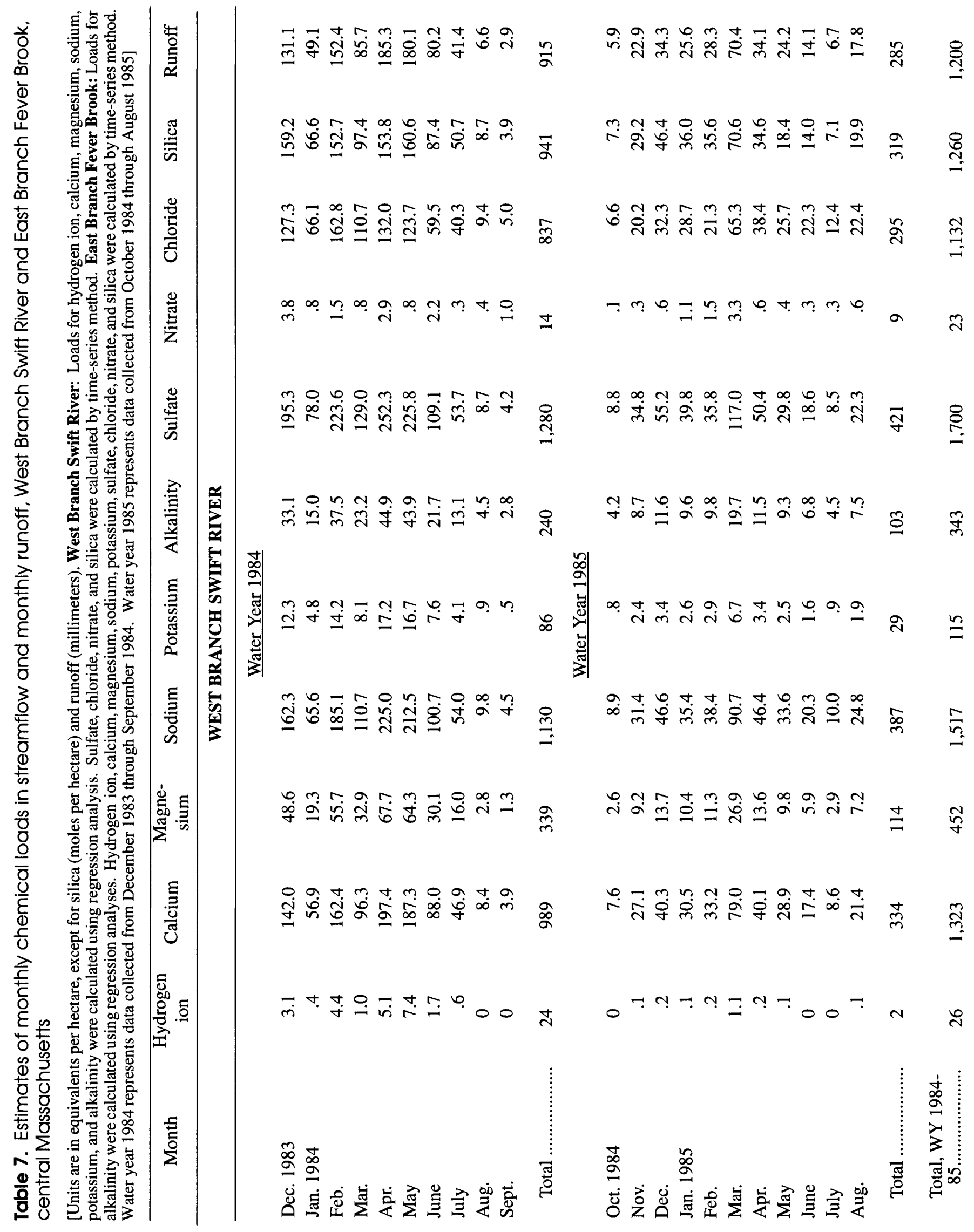




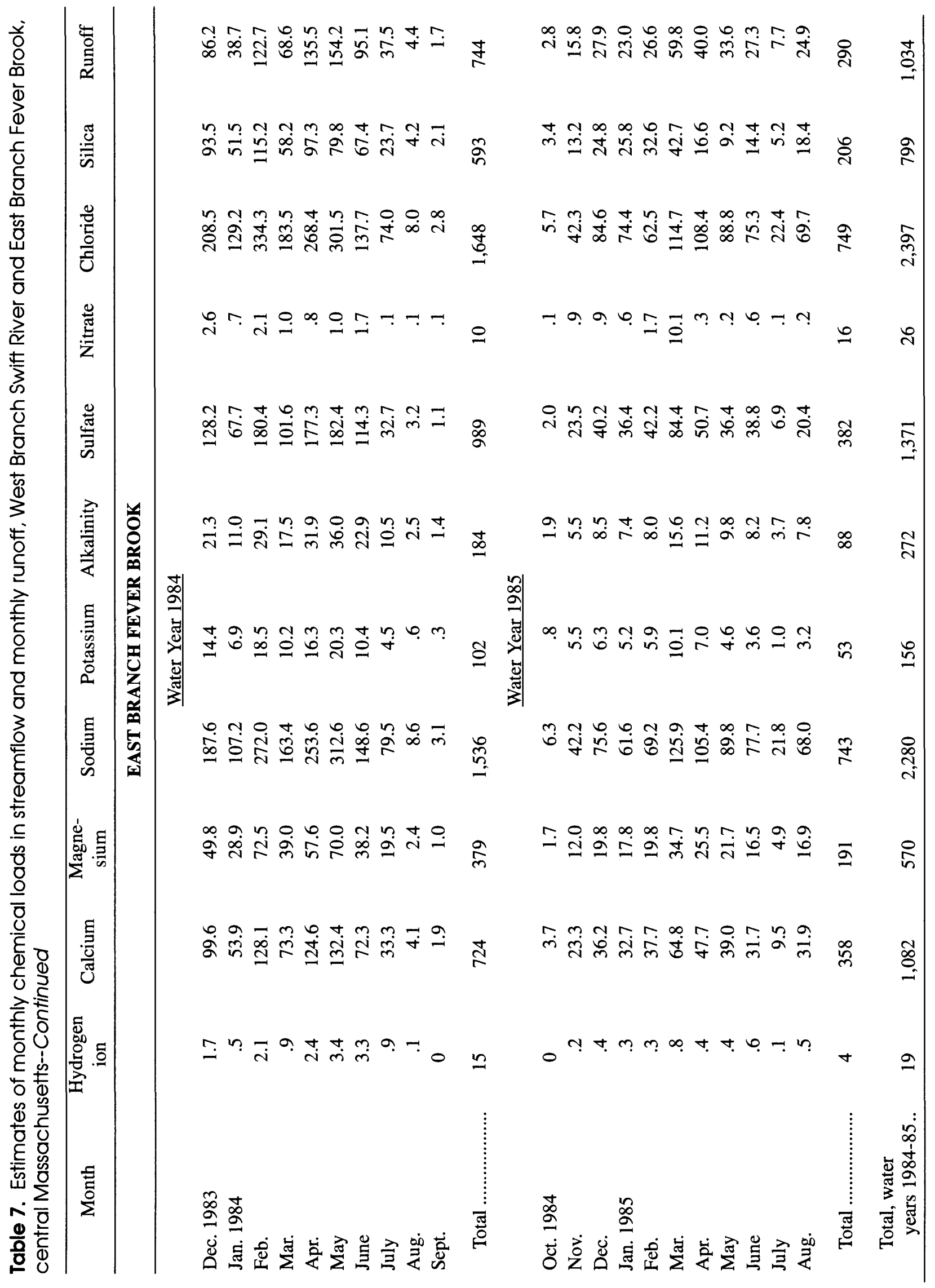


Table 8. Fluxes of major solutes and water, West Branch Swift River and East Branch Fever Brook Basins, central Massachusetts

[Fluxes are given in equivalents per hectare, except for silica (moles per hectare) and water (millimeters). Net flux is calculated as input (wet deposition) minus output (stream load), after adjustment for deicing salts. Water year 1984 represents data collected from December 1983 through September 1984. Water year 1985 represents data collected from October 1984 through August 1985]

Solute Input Output $\begin{gathered}\text { Salt-corrected Net flux } \\ \text { output }\end{gathered}$

\section{WEST BRANCH SWIFT RIVER}

\begin{tabular}{|c|c|c|c|}
\hline \multicolumn{4}{|c|}{ Water Year 1984} \\
\hline Hydrogen ion...... 607 & 24 & 24 & 583 \\
\hline Calcium .............. 68 & 989 & 951 & -883 \\
\hline Magnesium.......... & 339 & 334 & -287 \\
\hline Sodium .............. 130 & 1,130 & 438 & -308 \\
\hline Potassium ........... 15 & 86 & 86 & -71 \\
\hline Alkalinity............. & 240 & 240 & -240 \\
\hline Sulfate ............... 424 & 1,280 & 1,267 & -843 \\
\hline Nitrate................ 272 & 14 & 14 & 258 \\
\hline Chloride.............. 114 & 837 & 114 & 0 \\
\hline Silica....................... & 941 & 941 & -941 \\
\hline Water ................. 1,546 & 915 & 915 & 631 \\
\hline \multicolumn{4}{|c|}{ Water Year 1985} \\
\hline Hydrogen ion...... 854 & 2 & 2 & 852 \\
\hline Calcium ............... & 334 & 322 & -261 \\
\hline Magnesium.......... & 114 & 112 & -84 \\
\hline Sodium ................ & 387 & 171 & -102 \\
\hline Potassium ............ & 29 & 29 & -16 \\
\hline Alkalinity............. & 103 & 103 & -103 \\
\hline Sulfate ................. 610 & 421 & 417 & 193 \\
\hline Nitrate............... 370 & 9 & 9 & 361 \\
\hline Chloride.............. 70 & 295 & 70 & 0 \\
\hline Silica..................... & 319 & 319 & -319 \\
\hline Water ................. 969 & 285 & 285 & 684 \\
\hline \multicolumn{4}{|c|}{ Total for Water Years 1984-85 } \\
\hline Hydrogen ion...... 1,461 & 26 & 26 & 1,435 \\
\hline Calcium ............. 130 & 1,323 & 1,273 & $-1,144$ \\
\hline Magnesium......... 75 & 452 & 446 & -371 \\
\hline Sodium .............. 198 & 1,517 & 609 & -411 \\
\hline Potassium ............ & 115 & 115 & -88 \\
\hline Alkalinity............. & 343 & 343 & -343 \\
\hline Sulfate .............. 1,034 & 1,700 & 1,684 & -650 \\
\hline Nitrate............... 641 & 23 & 23 & 618 \\
\hline Chloride.............. 184 & 1,132 & 184 & 0 \\
\hline Silica..................... & 1,260 & 1,260 & $-1,260$ \\
\hline Water .................. 2,515 & 1,200 & 1,200 & 1,315 \\
\hline
\end{tabular}

\section{EAST BRANCH FEVER BROOK}

\begin{tabular}{lrrrc}
\hline \multicolumn{5}{c}{ Water Year 1984 } \\
Hydrogen ion....... 607 & 15 & 15 & 592 \\
Calcium ................ 68 & 724 & 510 & -442 \\
& & & ${ }^{4} 469-546$ & ${ }^{1}[-478]-[-401]$
\end{tabular}

Solute Input Output $\begin{gathered}\text { Salt-corrected Net flux } \\ \text { output }\end{gathered}$

\section{EAST BRANCH FEVER BROOK--Continued}

\begin{tabular}{|c|c|c|c|}
\hline \multicolumn{4}{|c|}{ Water Year 1984} \\
\hline Magnesium.......... 47 & 379 & $\begin{array}{c}286 \\
1265-305\end{array}$ & $\begin{array}{c}-239 \\
{ }^{1}[-258]-[-218]\end{array}$ \\
\hline Sodium ................ 130 & 1,536 & $\begin{array}{c}317 \\
{ }^{1} 250-383\end{array}$ & $\begin{array}{c}-187 \\
{ }^{1}[-253]-[-121]\end{array}$ \\
\hline Potassium ............ 15 & 102 & 102 & -87 \\
\hline Alkalinity.................. & 184 & 184 & -184 \\
\hline Sulfate …….......... 424 & 989 & 963 & -539 \\
\hline Nitrate................. 272 & 10 & 10 & 262 \\
\hline Chloride............... 114 & 1,648 & 114 & 0 \\
\hline Silica.......................... & 593 & 593 & -593 \\
\hline Water ................... 1,546 & 744 & 744 & 802 \\
\hline \multicolumn{4}{|c|}{ Water Year 1985} \\
\hline Hydrogen ion...... 854 & 4 & 4 & 850 \\
\hline Calcium .................... & 358 & $\begin{array}{c}307 \\
{ }^{2} 295-315\end{array}$ & $\begin{array}{c}-246 \\
{ }^{1}[-254]-[-234]\end{array}$ \\
\hline Magnesium........... & 191 & $\begin{array}{c}173 \\
{ }^{1} 166-177\end{array}$ & $\begin{array}{c}-145 \\
{ }^{1}[-149]-[-138]\end{array}$ \\
\hline Sodium .................. & 743 & $\begin{array}{c}110 \\
{ }^{1} 87-133\end{array}$ & 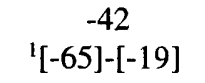 \\
\hline otassium ............ 13 & 53 & 53 & -40 \\
\hline Alkalinity................ & 88 & 88 & -88 \\
\hline Sulfate ……............. 610 & 382 & 370 & 240 \\
\hline Nitrate.................. 370 & 16 & 16 & 354 \\
\hline Chloride................. & 749 & 70 & 0 \\
\hline 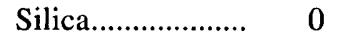 & 206 & 206 & -206 \\
\hline Water ................... 969 & 290 & 290 & 679 \\
\hline \multicolumn{4}{|c|}{ Total for Water Years 1984-85 } \\
\hline Hydrogen ion...... 1,461 & 19 & 19 & 1,442 \\
\hline Calcium ................ 130 & 1,082 & $\begin{array}{c}816 \\
{ }^{1} 764-861\end{array}$ & $\begin{array}{c}-688 \\
{ }^{1}[-732]-[-635]\end{array}$ \\
\hline Magnesium .......... 75 & 570 & $\begin{array}{c}459 \\
1432-482\end{array}$ & $\begin{array}{c}-384 \\
{ }^{1}[-407]-[-356]\end{array}$ \\
\hline Sodium ................. 198 & 2,280 & $\begin{array}{c}427 \\
1337-516\end{array}$ & $\begin{array}{c}-229 \\
{ }^{1}[-318]-[-139]\end{array}$ \\
\hline Potassium ............. & 156 & 156 & -128 \\
\hline Alkalinity.............. & 272 & 272 & -272 \\
\hline Sulfate ................ 1,034 & 1,371 & 1,333 & -299 \\
\hline Chloride............... 184 & 2,397 & 184 & 0 \\
\hline Nitrate...................... 641 & 26 & 26 & 615 \\
\hline Silica............................ & 799 & 799 & -799 \\
\hline Water ..................... 2,515 & 1,034 & 1,034 & 1,481 \\
\hline
\end{tabular}

\footnotetext{
${ }^{1}$ Ranges reflect uncertainty in deicing salt adjustments.
} 
values for net flux. More than 98 percent of hydrogen ion and as much as 96 percent of nitrate that entered each basin by wet deposition was retained. Net export was observed for all other major solutes. The net flux of alkalinity was 26 percent greater at Swift River than at Fever Brook. After adjustments for deicing salts, the net export of potassium was greater at Fever Brook, calcium and sodium export was greater at $\mathrm{Swift}$ River, and magnesium export was about the same in each basin (table 8). The total net export of base cations and silica was higher at Swift River relative to Fever Brook by 41 and 58 percent, respectively. This comparison of net solute fluxes suggests a higher rate of weathering in the Swift River Basin. Although there may be loss of silica to diatom uptake at Fever Brook, the disproportionately higher net export of silica at Swift River is indicative of a different stoichiometry of weathering. About two times more sulfate was exported at Swift River than at Fever Brook; the additional sulfate export at Swift River partly balances the additional base-cation export.

During the 21-month study period, the Swift River and Fever Brook Basins yielded net base-cation fluxes of 2,014 and 1,429 eq/ha (equivalents per hectare), respectively, after adjustment for deicing salts (calculated from table 8). At Fever Brook, the net retention of hydrogen ion, 1,442 eq/ha, thus could account for the entire net flux of base cations. Because some of the hydrogen ion retention was balanced by nitrate retention, each basin had an excess export of cations that was necessarily balanced by the export of alkalinity and sulfate. Accordingly, the export of alkalinity and sulfate was greater at Swift River than at Fever Brook.

\section{FACTORS AFFECTING WATER QUALITY AND NET FLUX OF SOLUTES}

\section{Precipitation Quality}

Precipitation entering the Swift River and Fever Brook Basins was a dilute mixture of sulfuric and nitric acids, and minor amounts of base cations and chloride (table 2). Stream water leaving the basins was much enriched in base cations, which were balanced by sulfate, chloride (predominantly from deicing salts) and bicarbonate alkalinity (alkalinity in a low DOC circumneutral freshwater stream is virtually all as bicarbonate). Thus, processes within the basins transform the acidic precipitation into a moderately buffered solution of sulfate and chloride salts. Precipitation chemistry may appear to have a limited role in final stream chemistry. However, there are three important ways in which stream chemistry is affected by the precipitation chemistry.

The first effect of precipitation chemistry on stream chemistry is related to the retention of hydrogen ion in the drainage basin; inputs of $\mathrm{H}^{+}$in precipitation are much greater than outputs of $\mathrm{H}^{+}$in streamflow (table 8). $\mathrm{H}^{+}$is retained through consumption of protons in weathering reactions, or by ion exchange. There is much debate whether the increased acidity of modern precipitation causes increased weathering rates (Drever, 1988). However, the possibility that increased acidity may drive ion-exchange reactions that alter the stoichiometry of cations in soil solution, and ultimately, stream water, is generally recognized. The effect of precipitation acidity on ion exchange is seen as a perturbation of a steady-state system; cation populations on exchange sites are in the process of adjustment to elevated inputs of hydrogen ion.

The second effect of precipitation chemistry on stream chemistry is evident during high flows. In both Swift River and Fever Brook Basins, alkalinity reached minimum concentrations of $1 \mu \mathrm{eq} / \mathrm{L}$ (from typical concentrations near $100 \mu \mathrm{eq} / \mathrm{L}$ ) during the study (figs. 9 and 10). These near-acidification events are attributed to the dilution of base-flow stream water with precipitation acidity. If precipitation were not acidic or only slightly acidic, such mixing would result in a much less pronounced dilution of acidity. Thus, at high flows, the acidity of precipitation contributes to the alkalinity decrease in the streams.

The third effect of precipitation chemistry on stream chemistry results from the high concentrations of sulfate in precipitation. Disregarding the effect of deicing salts, sulfate is the dominant anion in precipitation and stream water. Sulfate inputs and outputs are approximately balanced (table 8 ). Some sulfate may be released from weathering of sulfidic schist, which is more abundant in Fever Brook Basin; however, this source is believed to be minor relative to atmospheric sulfate. The dominance of sulfate in stream water appears to be a direct consequence of high atmospheric inputs. In pre-industrial times, bicarbonate most likely was the dominant anion (Reuss and Johnson, 1986). Sulfate serves as a mobile anion to transport base 
cations to the stream, thus cation export is likely to be greater than it would be in a bicarbonate-dominated system.

\section{Basin Hydrogeology}

Differences in stream chemistry in Swift River and Fever Brook Basins are attributed in part to differences in hydrology in the two basins. The hydrology, in turn, is affected by the type and distribution of surficial geologic deposits. In deposits that have high hydraulic conductivities, such as outwash sands, ground water travels quickly to the stream and there is little opportunity for weathering. In deposits that have low hydraulic conductivities, such as dense basal tills, ground water has a long residence time and weathering reactions can be extensive.

Swift River is more responsive to storms than Fever Brook, as indicated by its more rapid hydrograph rise and recession. However, Swift River has a higher percentage of base flow and overall runoff than Fever Brook (table 1). These factors indicate greater soil/ water contact time at Swift River, which would tend to increase mineral weathering and solute transport. The higher concentration of weathering products (silica, base cations, and alkalinity) at Swift River relative to Fever Brook (table 3), therefore, is consistent with the hydrology of the two basins.

\section{Hydrologic Flow Paths}

Stream chemistry reflects in part the relative contributions of the various hydrologic flow paths to streamflow. Associated with each of the different hydrologic flow paths-channel interception of canopy throughfall, saturation-excess overland flow, unsaturated subsurface flow, ground-water flow-is a different set of factors that control the chemical evolution of that water. Some of these factors include: differences in mineralogy, contact time (flow velocity), ion-exchange capacity, oxidation/reduction state, microbiological activity, and abundance of tree roots. At low flows, streamflow is primarily composed of ground water that is rich in weathering products (silica, base cations, and alkalinity). During storms, streamflow is primarily composed of water from shallow flow paths, such as channel interception and saturation-excess overland flow, which are lower in solutes from weathering, and higher in solutes associated with precipitation including sulfate, nitrate, and hydrogen ion. This type of conceptual model, in which stream chemistry is considered a product of the mixing of waters from different flow paths, each with a distinctive chemistry, is widely used to interpret stream chemistry and hydrology (Hooper and others, 1990).

The chemistry of ground water varied greatly in each basin (table 4), and differed in turn from the chemistry of base flow at the outlet gaging stations (table 3). This pattern indicates that the ground water sampled in each basin probably was not representative of that basin as a whole. Therefore, the water quality of base flow at each gaging station was considered to be a more reliable indicator of the composition of ground water discharging from that basin. Total base-cation loads exported from each basin in ground-water discharge were calculated using the quantified base-flow component of discharge from December 1983 through August 1985 with the flow-weighted average concentration of each chemical solute in selected samples of base flow collected at the gaging stations (table 3 ).

At the Swift River gaging station, ground-water discharge accounted for 53 percent of total discharge and 55 percent of the flux of base cations. At the Fever Brook gaging station, ground-water discharge accounted for 42 percent of total discharge and 50 percent of the flux of base cations. Significantly, transport of hydrogen ion in base flow accounted for only 17 and 27 percent of the stream loads of hydrogen ion in Swift River and Fever Brook, respectively. The disproportionately higher export of base cations and lower export of hydrogen ion in ground water relative to those in total flow indicate that a greater degree of mineral dissolution and acid neutralization results when inputs of atmospheric acidity follow flow paths that allow considerable contact time of water with minerals in the basins before discharging to the streams.

At Fever Brook, surface-water impoundments significantly affected the temporal pattern of solute fluxes. Runoff water was retained in the impoundments where it mixed with older ground water, thus attenuating variations in solute concentrations and obscuring concentration-discharge relations. The impoundments appeared to have the most pronounced effect on alkalinity and sulfate. The significant concentration-discharge relation for alkalinity was attributed to the biologic production of alkalinity in the impoundments, which may have been the dominant alkalinity 
generating mechanism. Alkalinity increased during summer and autumn as flow decreased and biological activity increased. Alkalinity production was associated with sulfate reduction; sulfate concentrations decreased at Fever Brook during base-flow conditions in summer, in contrast to the sustained elevated sulfate concentrations during base flow at Swift River (figs. 9 and 10).

\section{Mineral Weathering}

Differences in chemical concentrations and fluxes at the Swift River and the Fever Brook outlet gaging stations reflect contrasts in bedrock lithology and mineralogy of the two basins. The higher export of silica, base cations, and alkalinity at Swift River is a general indicator of greater weathering in that basin. The stoichiometry of weathering differs in the two basins as well. Net export of calcium and sodium is considerably higher at Swift River, net export of potassium is higher at Fever Brook, and net export of magnesium is about the same in the two basins. In general, the granitic lithologies of the Swift River Basin are resistant to weathering. However, a high proportion of the net cation export at Swift River, in particular the high calcium export, is attributed to weathering of the hornblende gabbro in the southeastern subcatchment (fig. 2). In the Fever Brook Basin, the amphibolite-schist lithology is relatively easily weathered. The greater relative export of magnesium and potassium at Fever Brook probably results from the weathering of hornblende, potassium feldspar, biotite, and (or) muscovite. The sodium flux probably derives from the weathering of plagioclase and (or) hornblende.

In Fever Brook Basin, the more easily weathered suite of minerals, coupled with the gentler topography, should be conducive to a higher rate of weathering compared to Swift River Basin. Most tributaries in the Swift River Basin have dilute chemistry with low alkalinity, indicative of limited weathering (table 4). The relative enrichment of solutes by weathering at the Swift River outlet gaging station is partly attributable to the composition of the tributary draining the southeast subbasin that is underlain by gabbro. Although this subbasin comprises only 11.2 percent of the total basin area, it contributes nearly 25 percent of the total base cations, 16 percent of the total silica, and 77 percent of the total alkalinity exported from the basin. These figures were calculated from average solute concentrations in the tributary streams, assuming that streamflow in each tributary is proportional to its area.
The capability of minerals in the basins to neutralize acidic inputs is reflected in the enrichment of base cations in ground water (table 4). Water enters the basins as precipitation and continuously evolves in chemical composition as it contacts and reacts with minerals in the soil and surficial deposits (till and stratified drift) before discharging to the streams. The concentration of base cations increases in the water as primary minerals are dissolved by carbonic and mineral acids. Prolonged contact between water and minerals enables chemical reactions to proceed more completely and increases the degree of neutralization of acids.

Except for the small amounts in precipitation, base cations are ultimately derived from mineral weathering. The possible mineral-weathering reactions in the Swift River and Fever Brook Basins generally involve incongruent dissolution of primary aluminosilicate minerals in the soil and shallow aquifer. Typically, the primary minerals in igneous and metamorphic source rocks are metastable, owing to their formation at pressures, temperatures, and in the presence of fluids that are not found in weathering environments at the Earth's surface. Generally, the higher the temperature and pressure at which a mineral formed, the more reactive it is at the Earth's surface (Garrels and Christ, 1965). However, because of their strong chemical bonding and structural framework, silicate minerals weather slowly and therefore yield relatively small quantities of base cations and alkalinity in comparison to carbonates and other minerals.

The dissolution of aluminosilicate minerals is driven by the acidic hydrogen ion. Primary minerals react with water and hydrogen ion to yield base cations (calcium, magnesium, sodium, potassium) and silica to solution and form new aluminous mineral phases (usually clay minerals) that are more stable at the Earth's surface. This reaction was generalized by Bricker and others (1968) as:

$$
\begin{aligned}
& \text { Primary aluminosilicate }+\mathrm{H}^{+}+\mathrm{H}_{2} \mathrm{O}=\text { Secondary } \\
& \text { aluminum-rich minerals }+ \text { base cations }+\mathrm{H}_{4} \mathrm{SiO}_{4} \text {, }
\end{aligned}
$$

In this reaction, aluminum is assumed to be conserved in solid phases. This assumption appears to be valid in the study drainage basins, given the low concentrations of dissolved aluminum in ground water and base-flow stream samples. 
In most soil and ground-water environments, the most important source of hydrogen ions to drive weathering reactions is carbonic acid. For a system open to the atmosphere, a continuous source of carbon dioxide gas is in contact with soil water. Additional carbon dioxide may be supplied by biological processes, such as plant respiration. Carbon dioxide and water react to form carbonic acid, which dissociates to produce bicarbonate and hydrogen ion, described as follows:

$$
\mathrm{CO}_{2}+\mathrm{H}_{2} \mathrm{O}=\mathrm{H}_{2} \mathrm{CO}_{3}=\mathrm{HCO}_{3}^{-}+\mathrm{H}^{+}
$$

Other sources of hydrogen ion include organic acids in the soil zone, weathering of sulfide minerals, and strong mineral acids in precipitation.

Possible weathering reactions involving minerals identified in the bedrock and in soil samples from Swift River and Fever Brook Basins include:

$$
\begin{gathered}
\mathrm{CaAl}_{2} \mathrm{Si}_{2} \mathrm{O}_{8} \text { (anorthite) }+2 \mathrm{CO}_{2}+3 \mathrm{H}_{2} \mathrm{O}=\mathrm{Ca}^{2+}+ \\
2 \mathrm{HCO}_{3}^{-}+\mathrm{Al}_{2} \mathrm{Si}_{2} \mathrm{O}_{5}(\mathrm{OH})_{4}(\text { kaolinite })
\end{gathered}
$$

$$
\begin{aligned}
& 2 \mathrm{NaAlSi}_{3} \mathrm{O}_{8}(\text { albite })+2 \mathrm{CO}_{2}+11 \mathrm{H}_{2} \mathrm{O}=2 \mathrm{HCO}_{3}^{-}+ \\
& 2 \mathrm{Na}^{+}+4 \mathrm{H}_{4} \mathrm{SiO}_{4}+\mathrm{Al}_{2} \mathrm{Si}_{2} \mathrm{O}_{5}(\mathrm{OH})_{4}(\text { kaolinite }),
\end{aligned}
$$

$$
\begin{gathered}
3 \mathrm{KAlSi}_{3} \mathrm{O}_{8} \text { (microcline) }+2 \mathrm{H}^{+}+12 \mathrm{H}_{2} \mathrm{O}=2 \mathrm{~K}^{+}+ \\
6 \mathrm{H}_{4} \mathrm{SiO}_{4}+\mathrm{KAl}_{3} \mathrm{Si}_{3} \mathrm{O}_{10}(\mathrm{OH})_{2} \text { (illite) } \\
3 \mathrm{~K}_{2}\left(\mathrm{Mg}_{3} \mathrm{Fe}_{3}\right) \mathrm{Al}_{2} \mathrm{Si}_{6} \mathrm{O}_{20}(\mathrm{OH})_{4}(\text { biotite })+ \\
16 \mathrm{H}_{2} \mathrm{O}+20 \mathrm{H}^{+}=6 \mathrm{~K}^{+}+3 \mathrm{Mg}^{2+}+3 \mathrm{Fe}^{2+}+8 \mathrm{H}_{4} \mathrm{SiO}_{4} \\
+2\left(\mathrm{Mg}_{3} \mathrm{Fe}_{3}\right)\left(\mathrm{Al}_{3} \mathrm{Si}_{5} \mathrm{O}_{20}\right) \bullet\left(8 \mathrm{H}_{2} \mathrm{O}\right) \\
\text { (vermiculite) }
\end{gathered}
$$

$$
\begin{aligned}
(\mathrm{Ca}, \mathrm{Na})_{2-3}\left(\mathrm{Mg}, \mathrm{Fe}^{2+}, \mathrm{Fe}^{3+}, \mathrm{Al}\right)_{5}(\mathrm{Al}, \mathrm{Si})_{8} \mathrm{O}_{22}(\mathrm{OH})_{2} \\
(\text { hornblende })+v \mathrm{H}^{+}+w \mathrm{H}_{2} \mathrm{O}=x \mathrm{Ca}^{2+}+y \mathrm{Na}^{+}+z \mathrm{Mg}^{2+} \\
+n \mathrm{H}_{4} \mathrm{SiO}_{4}+2\left(\mathrm{Mg}_{3} \mathrm{Fe}_{3}\right)\left(\mathrm{Al}_{3} \mathrm{Si}_{5} \mathrm{O}_{20}\right) \bullet\left(8 \mathrm{H}_{2} \mathrm{O}\right) \\
\text { (vermiculite), }
\end{aligned}
$$

Equations (8) and (9) represent the weathering of the calcium and sodium end members of plagioclase to kaolinite. True plagioclase nearly always has a composition intermediate between the end members, thus equations (8) and (9) could be replaced with a single reaction if that composition were known. The weathering of microcline to illite (eq. 10) generally is less important, although illite was detected in all soil samples. Vermiculite was the dominant clay mineral in most soil samples, indicating that the weathering of biotite and hornblende to vermiculite (eqs. 11 and 12) may be important reactions in the basins. In equation 12 , the quantities in italics are variables, because hornblende composition varies widely.

Although the overall net export of solutes was higher at Swift River (table 8), the export of magnesium was about the same in each basin, and the export of potassium was higher at Fever Brook than at Swift River. This implies that the weathering of hornblende (eq. 12) and (or) biotite (eq. 11) was relatively more important at Fever Brook. At Cadwell Creek, $14 \mathrm{~km}$ south of the Swift River outlet gaging station, hornblende was relatively rich in calcium and magnesium and poor in sodium (Michener, 1983). Hornblende weathering probably was responsible for the relatively high magnesium export at Fever Brook, given that hornblende is abundant in the basin and is easily weathered (April and others, 1986). Biotite (eq. 11) is more easily weathered than microcline (eq. 10), and thus was the most likely source for the higher potassium export from Fever Brook.

If the hornblende compositional analyses of Michener (1983) are indicative, hornblende in the region is too low in sodium to account for the sizeable sodium fluxes (after deicing salt corrections) at each of the two basin outlet gaging stations. The more likely source of sodium is plagioclase weathering (eq. 9). Michener (1983) found that the average plagioclase composition at Cadwell Creek was $\mathrm{An}_{20}$, or 80 percent of the sodium end member. Plagioclase in the Carter and Mundberry Basins, adjacent to Fever Brook, also was high in sodium (Elizabeth Knapp, University of Massachusetts, written commun., 1990). Weathering of sodium plagioclase has been the dominant source of sodium to solution in other studies of drainage basins (Katz and others, 1985; Velbel, 1985; Clayton, 1988; Peters, 1989b). As plagioclase weathers to kaolinite, two moles of silica are released for each mole of sodium (eq. 9), but no silica accompanies the release of calcium (eq. 8). Thus, in the absence of other weathering reactions releasing or consuming sodium or silica, the sodium:silica ratio should be 0.5 . The sodium:silica ratio is 0.33 at Swift River and 0.29 at Fever Brook. These ratios suggest that plagioclase weathering accounts for a considerable amount of the silica flux, and probably is more important at Swift River. At Swift River, the high net export of calcium, and the high 
calcium:silica and calcium:magnesium ratios compared to Fever Brook, result from the abundance of calcic plagioclase in the southeast tributary.

The equilibrium solubility model WATEQF (WATer EQuilibrium-Fortran) was used to calculate the equilibrium speciation of inorganic ions and ion complexes in the two basins (Plummer and others, 1976; thermodynamic data current with the 1984 version of the program). The saturation index, defined as the log of the ratio of the ion activity product to the thermodynamic equilibrium constant, was computed in the model for possible mineral phases (table 9). Saturation indexes less than zero for a given mineral imply that the solution is undersaturated with respect to that mineral; saturation indexes greater than zero imply that the solution is supersaturated with respect to that mineral. Undersaturated conditions favor dissolution whereas supersaturated conditions favor precipitation. Saturation indexes were determined from analyses of ground water and stream base flow, because those waters had the longest contact time with minerals of the soil, till, and bedrock. In each basin, all waters analyzed were undersaturated with respect to the primary minerals and were nearing saturation or were somewhat supersaturated with respect to secondary minerals postulated to be forming as weathering products. Based on the analysis, kaolinite was the secondary mineral most favored to be forming in each basin (table 9).

Stability diagrams of mineral equilibria illustrate conditions of chemical equilibrium of selected minerals in contact with natural waters. If it is assumed that all reactions occur at $25^{\circ} \mathrm{C}$ and that aluminum is conserved in the solid phases, the stability of one mineral relative to another can be evaluated, as can the degree of saturation of that water with respect to a given mineral. Activities of aqueous species calculated by use of WATEQF were plotted on activity diagrams for the

Table 9. Saturation index for some minerals for flow-weighted-average base-flow and ground-water samples in West Branch Swift River and East Branch Fever Brook Basins, central Massachusetts

[Saturation index: The saturation index is the log of the ratio of ion activity product to the thermodynamic equilibrium constant, $K$, at the temperature of the water sample]

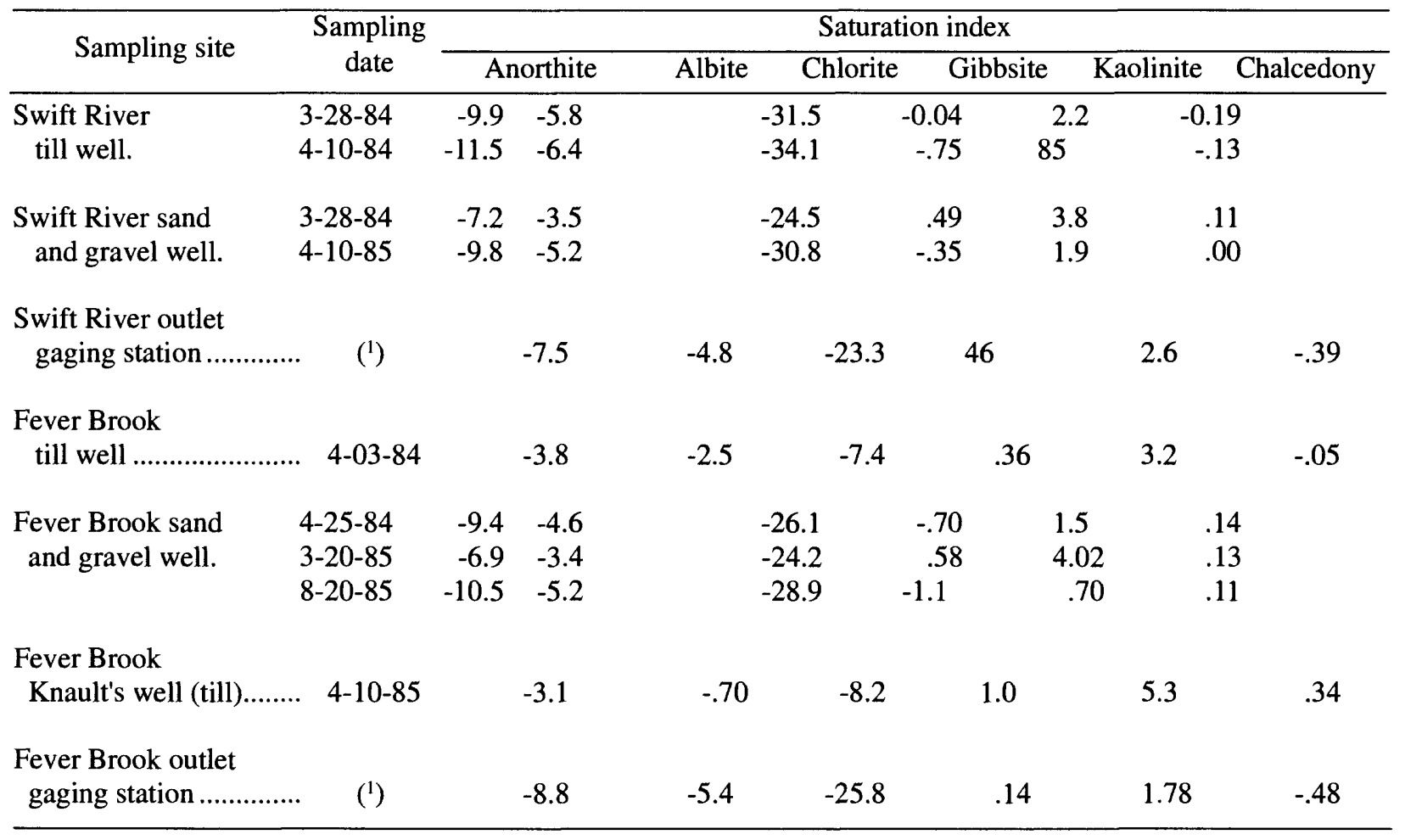

${ }^{1}$ Flow-weighted-average base flow. 
systems $\mathrm{CaO}-\mathrm{Al}_{2} \mathrm{O}_{3}-\mathrm{SiO}_{2}-\mathrm{H}_{2} \mathrm{O}$ and $\mathrm{K}_{2} \mathrm{O}-\mathrm{Al}_{2} \mathrm{O}_{3}-\mathrm{SiO}_{2}-$ $\mathrm{H}_{2} \mathrm{O}$ at $25^{\circ} \mathrm{C}$ (fig. 14). In these simplified four-component systems, kaolinite was the most stable mineral. The field evidence provided some support for this analysis, as kaolinite was detected in minor amounts in nearly all soil samples. However, gibbsite also was detected in several samples.

\section{Aluminum Geochemistry}

The solubility of some aluminum minerals is enhanced by a decrease in $\mathrm{pH}$ (Drever, 1988). Increased aluminum concentrations associated with acidic deposition have been linked to fish mortality (Driscoll and others, 1980; Schofield and Trojnar, 1980), and have been implicated as a contributing cause of forest dieback in Germany (Ulrich, 1983). Aluminum is most toxic in the labile, monomeric form $\left(\mathrm{Al}^{3+}\right)$; its effects are more benign when complexed with either an inorganic ligand, such as fluoride or hydroxide, or with an organic ligand. Aluminum toxicity is low in organicrich waters, even when the $\mathrm{pH}$ is low, because most of the aluminum is organically complexed. Aluminum geochemistry is important not only from the standpoint of aluminum toxicity, but also because aluminum has a significant effect on the geochemical cycles of phosphorous, carbon, and trace metals, and because it plays an important role in $\mathrm{pH}$ buffering (Driscoll, 1985).

\section{Seasonal Variations}

The rapid increase in aluminum concentrations in response to increased flows at Swift River was consistent with the surficial geology of the basin. The thin soils and steep ridges lead to rapid runoff and short contact time of storm water with rock and soil materials, allowing minimal neutralization of the acidic inputs. Hydrogen-ion acidity can rapidly mobilize aluminum in near-surface soil (McAvoy, 1989). Relations between aluminum concentration and discharge contrasted sharply to relations between other dissolved solutes and discharge, in which solute concentrations generally decreased with increasing discharge (figs. 9, 10, and 13).

Aluminum concentration is frequently affected by variations in $\mathrm{pH}$ and DOC. At Swift River, aluminum concentration increases were associated with concurrent increases in hydrogen ion concentration (fig. 9), and there was a significant correlation between aluminum and $\mathrm{pH}$ (fig. 15). Elevated concentrations of hydrogen ion may have caused the increase in aluminum through the dissolution of aluminum-bearing minerals in the soils, such as gibbsite $\left[\mathrm{Al}(\mathrm{OH})_{3}\right]$ (Johnson, 1979). Alternatively, increases in aluminum may be attributed to the replacement of hydrogen for aluminum on cation-exchange sites; ion exchange caused the episodic increases of aluminum during high-runoff periods at a drainage basin in Massachusetts, as acidic runoff flowed predominantly through the shallow soil zone (McAvoy, 1989).

At Fever Brook, aluminum concentrations were poorly correlated with $\mathrm{pH}$ (fig. 15). Hydrogen ion concentrations generally were higher in Fever Brook than in Swift River in late spring and summer (figs. 9, 10). The higher hydrogen ion concentrations (lower $\mathrm{pH}$ ) probably were maintained by organic acids, as suggested by the concurrent increase in DOC from 4 to $10 \mathrm{mg} / \mathrm{L}$ from late spring to early autumn. Water was highly colored in Fever Brook, because of the presence of organic anions. Despite variations in $\mathrm{DOC}$ and $\mathrm{pH}$, aluminum concentrations were fairly constant at Fever Brook. Except for the moderate increase in aluminum associated with the May 1984 flood, the few episodic increases that were detected at Fever Brook were not clearly correlated with changes in $\mathrm{pH}$ or DOC at high discharge; those increases, however, did coincide with high aluminum concentrations during the same period at Swift River. More frequent aluminum increases may have occurred at Fever Brook than were detected by weekly sampling. The higher chronic aluminum concentrations at Fever Brook may result from kinetic constraints on the precipitation of aluminum when aluminum-rich soil water, such as that sampled from the Fever Brook deep lysimeter (table 4), mixes with stream water during storm runoff (Burns, 1989).

\section{Spatial Variations}

At sites on Fever Brook tributaries, the relation between aluminum and $\mathrm{pH}$ was masked by the additional effect of DOC (table 4). Although mean DOC concentrations varied little among the surface-water sites, aluminum concentrations tended to decrease with increasing DOC. The outlet to Brooks Pond had the lowest aluminum, despite the lowest $\mathrm{pH}$ and highest DOC. The data from the tributary sites-though limited-are consistent with data from the main outlet (fig. 15), which suggest that there is no relation between 

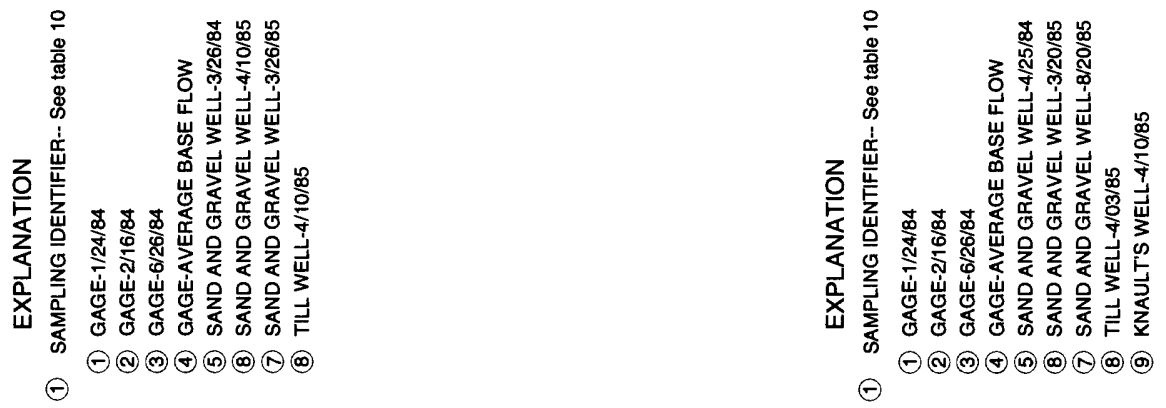


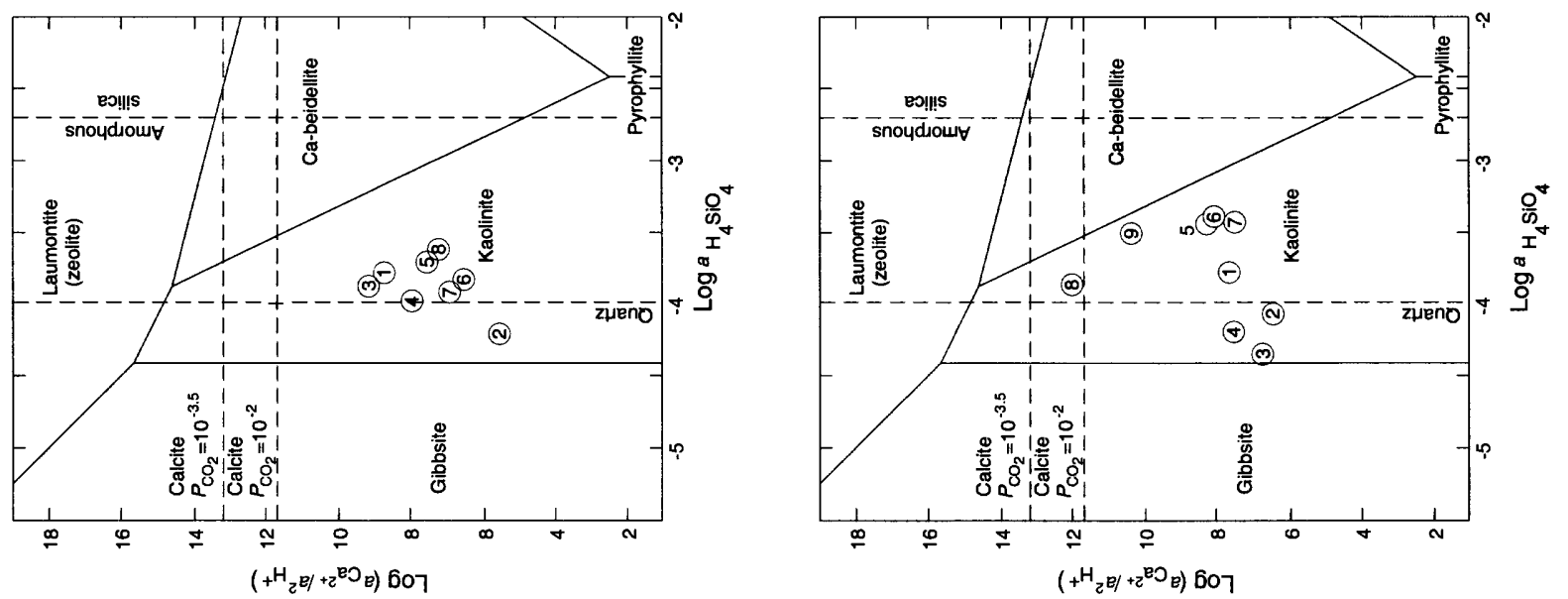

I

융

Оั

宁

O

ช $\frac{1}{0}$

응 는

$0 \stackrel{m}{7}$

I

क $\frac{\mathrm{O}}{\mathrm{O}}$

เิ
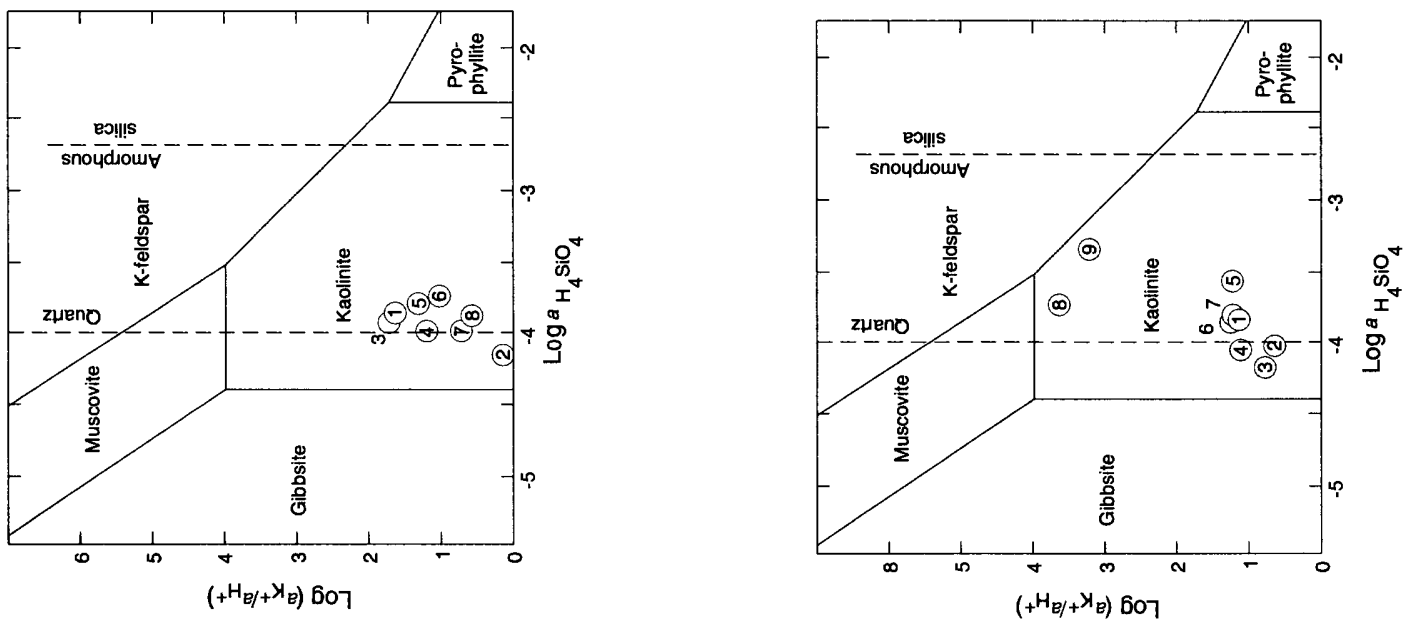

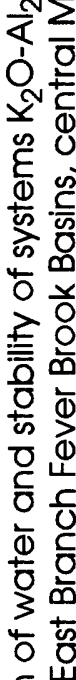

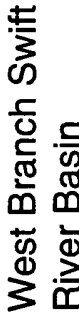

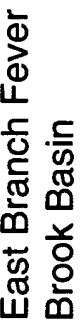




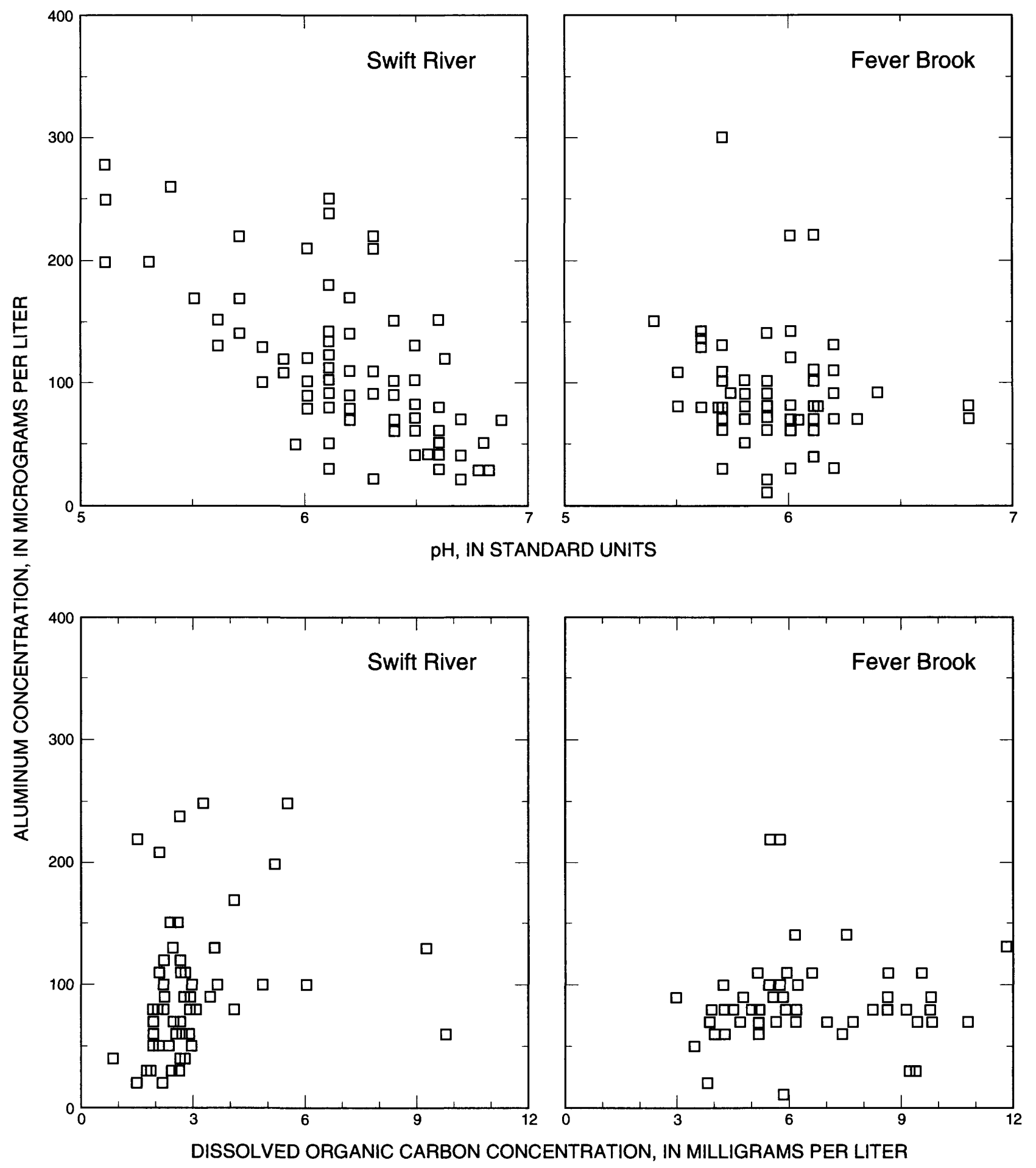

Figure 15. Relations between aluminum concentration and $\mathrm{pH}$, and aluminum concentration and dissolved organic carbon concentration, West Branch Swift River and East Branch Fever Brook, central Massachusetts. 
aluminum and DOC at Fever Brook. However, the high DOC, coupled with the low solubility of aluminum at pH greater than 5.5 (Johnson, 1979), assures that the most of the aluminum present is organically complexed.

Variations in aluminum concentrations at the outlet gaging stations, particularly at Swift River, can be explained by a mixing of waters from shallow (within the upper $30 \mathrm{~cm}$ of soil, including the organic horizon) and deep (deeper than $30 \mathrm{~cm}$, or within the mineral soil or till) flow pathways. Ground water in both basins had aluminum concentrations less than $40 \mu \mathrm{g} / \mathrm{L}$ (table 4). Ground water represents the deep flow path. As the ground-water component of flow increased, aluminum concentrations in the streams decreased. The low aluminum concentrations would be expected in ground water that has evolved to a stage where it is high in weathering solutes, $\mathrm{pH}$, and alkalinity. At Swift River, ground water has considerably less aluminum than the tributary streams, despite a comparably low $\mathrm{pH}$. This is attributed to the lower DOC in ground water relative to the streams. Storm runoff through the upper soil zone represents the shallow flow path. Increases in aluminum during high streamflow resulted as a higher percentage of streamflow was derived from this flow path. Soil waters had aluminum concentrations of several hundred micrograms per liter, consistent with the low $\mathrm{pH}$ (4.67 to 5.56) (table 4). Data were too limited to assess the effect of DOC in the high aluminum concentrations in soil waters.

The spatial pattern of aluminum concentrations in stream water is dependent on the spatial pattern of ground-water discharge to streamflow. Ground-water discharge to tributaries, particularly during storms or snowmelt runoff, is likely to be minimal compared to ground-water discharge at the outlet gaging stations. Unconsolidated surficial deposits along headwater tributaries are not as thick or extensive as those along the mainstem. Thus, precipitation inputs in the headwater areas follow shorter flow paths before discharging to streams, and have less contact time for neutralization reactions in the soil. A large pool of aluminum is readily available to infiltrating acidic waters, causing the high concentrations measured in soil waters (table 4). Therefore, the limited extent of surficial deposits in the headwater areas results in shorter hydrologic flow paths that tend to limit the degree to which acidic inputs are neutralized, leading to elevated concentrations of dissolved aluminum in the headwater streams.

\section{Chemical Speciation and Solubility of Dissolved Aluminum}

Aluminum speciation must be considered in assessing the effects of acid deposition on fish and other aquatic biota in the basins. Driscoll and others (1980) reported that low $\mathrm{pH}$ and high aluminum concentrations in streams in the Adirondack region of New York were most prevalent at high discharge conditions during storms and during snowmelt in the spring, and at low discharge conditions during the summer. The aluminum during snowmelt was predominantly labile inorganic aluminum, whereas during summer low flow it was predominantly organically complexed aluminum. Concentrations of dissolved aluminum in Swift River during spring snowmelt regularly exceeded $110 \mu \mathrm{g} / \mathrm{L}$, the threshold for toxicity to fish (Schofield and Trojnar, 1980). On the basis of the results of Driscoll and others (1980), most of this aluminum is assumed to be in the labile inorganic form, which is most toxic. "Fish kills" (DiNardo, 1984; Halliwell, 1985) as reported in nearby streams, may have been caused by high concentrations of labile aluminum. At Fever Brook, in contrast, aluminum toxicity to fish probably is minimal because more of the dissolved aluminum is organically complexed, and because episodic increases in aluminum concentration are less frequent.

WATEQF was used to calculate the equilibrium distribution of dissolved aluminum species for selected samples from Swift River and Fever Brook (table 10). WATEQF requires the "thermodynamically active" inorganic aluminum concentration to calculate aluminum speciation. From this study, only total dissolved aluminum concentrations, which included organically bound aluminum, were available. This limitation of the data is noted where it may affect interpretation of the model results.

Input to the model for each speciation calculation included aluminum and major dissolved solute concentrations, as well as temperature and $\mathrm{pH}$. The model calculated the activity, or effective concentration, of each ion and its complexes. Model results indicated that the aluminum hydroxide complex, $\mathrm{Al}(\mathrm{OH})_{2}{ }^{+}$, was the major form of aluminum in most samples, followed in importance by the fluoride complex, $\mathrm{AlF}^{2+}$. Monomeric aluminum, $\mathrm{Al}^{3+}$, generally comprised only 1 to 10 percent of total dissolved aluminum in each sample. Only one sample ( $\mathrm{pH}$ 5.1) collected during snowmelt runoff had $\mathrm{Al}^{3+}$ as the dominant form of dissolved aluminum 
Table 10. Chemical speciation of aqueous aluminum in selected water samples from West Branch Swift River and East Branch Fever Brook Basins, central Massachusetts

[Concentrations are given in moles per liter, in "p" notation (negative logarithm (base 10) of concentration). $\mathrm{Al}_{\text {total }}$, total dissolved aluminum. --, no data]

\begin{tabular}{|c|c|c|c|c|c|c|c|c|c|}
\hline $\begin{array}{lc} & \mathrm{S} \\
\text { Sampling site } & \mathrm{i} \\
& \mathrm{se} \\
\end{array}$ & $\begin{array}{l}\text { npling } \\
\text { ntifier } \\
\text { fig. 14) }\end{array}$ & Date & $\mathrm{pH}$ & $\mathrm{Al}_{\text {total }}$ & $\mathrm{Al}^{3+}$ & $\mathrm{Al}(\mathrm{OH})^{2+}$ & $\mathrm{Al}(\mathrm{OH})_{2}^{+}$ & $\mathrm{AIF}^{2+}$ & $\mathrm{AISO}_{4}^{+}$ \\
\hline \multicolumn{10}{|c|}{ WEST BRANCH SWIFT RIVER BASIN } \\
\hline $\begin{array}{l}\text { Swift River outlet } \\
\text { gaging station }\end{array}$ & $\begin{array}{l}1 \\
2 \\
3\end{array}$ & $\begin{array}{l}1-24-84 \\
2-16-84 \\
6-26-84\end{array}$ & $\begin{array}{l}6.6 \\
5.1 \\
6.7\end{array}$ & $\begin{array}{l}5.35 \\
5.13 \\
5.96\end{array}$ & $\begin{array}{l}7.38 \\
5.41 \\
9.31\end{array}$ & $\begin{array}{l}6.80 \\
6.34 \\
8.05\end{array}$ & $\begin{array}{l}5.39 \\
6.42 \\
6.04\end{array}$ & $\begin{array}{l}7.14 \\
5.59 \\
7.74\end{array}$ & $\begin{array}{r}8.72 \\
6.82 \\
10.62\end{array}$ \\
\hline Average base flow & 4 & -- & 6.2 & 5.66 & 8.35 & 7.08 & 5.72 & 6.96 & 9.52 \\
\hline $\begin{array}{l}\text { Swift River sand } \\
\text { and gravel well }\end{array}$ & $\begin{array}{l}5 \\
6\end{array}$ & $\begin{array}{l}3-28-84 \\
4-10-85\end{array}$ & $\begin{array}{l}6.0 \\
5.8\end{array}$ & $\begin{array}{l}6.72 \\
5.96\end{array}$ & $\begin{array}{l}8.12 \\
7.27\end{array}$ & $\begin{array}{l}7.85 \\
7.15\end{array}$ & $\begin{array}{l}6.80 \\
6.25\end{array}$ & $\overline{--}$ & $\begin{array}{l}9.51 \\
8.59\end{array}$ \\
\hline Swift River till well & $\begin{array}{l}7 \\
8\end{array}$ & $\begin{array}{l}3-28-84 \\
4-10-85\end{array}$ & $\begin{array}{l}5.7 \\
5.5\end{array}$ & $\begin{array}{l}5.66 \\
5.96\end{array}$ & $\begin{array}{l}6.51 \\
6.80\end{array}$ & $\begin{array}{l}6.59 \\
6.96\end{array}$ & $\begin{array}{l}5.85 \\
6.35\end{array}$ & $\begin{array}{l}6.72 \\
6.52\end{array}$ & $\begin{array}{l}7.74 \\
7.96\end{array}$ \\
\hline \multicolumn{10}{|c|}{ EAST BRANCH FEVER BROOK BASIN } \\
\hline $\begin{array}{l}\text { Fever Brook } \\
\text { gaging station }\end{array}$ & $\begin{array}{l}1 \\
2 \\
3\end{array}$ & $\begin{array}{l}1-24-84 \\
2-16-84 \\
6-26-84\end{array}$ & $\begin{array}{l}6.0 \\
5.6 \\
5.7\end{array}$ & $\begin{array}{l}5.43 \\
5.59 \\
4.66\end{array}$ & $\begin{array}{l}6.60 \\
6.52 \\
6.57\end{array}$ & $\begin{array}{l}6.64 \\
6.96 \\
6.00\end{array}$ & $\begin{array}{l}5.82 \\
6.54 \\
4.74\end{array}$ & $\begin{array}{l}5.77 \\
5.72 \\
5.68\end{array}$ & $\begin{array}{l}7.96 \\
7.96 \\
8.05\end{array}$ \\
\hline Average base flow & 4 & -- & 5.9 & 5.72 & 8.01 & 7.30 & 5.89 & 6.55 & 9.22 \\
\hline $\begin{array}{l}\text { Fever Brook sand } \\
\text { and gravel well }\end{array}$ & $\begin{array}{l}5 \\
6 \\
7\end{array}$ & $\begin{array}{l}4-25-84 \\
3-20-85 \\
8-20-85\end{array}$ & $\begin{array}{l}6.2 \\
7.5 \\
5.9\end{array}$ & $\begin{array}{l}6.72 \\
5.43 \\
6.43\end{array}$ & $\begin{array}{l}8.60 \\
7.27 \\
8.42\end{array}$ & $\begin{array}{l}8.17 \\
6.82 \\
8.12\end{array}$ & $\begin{array}{l}6.96 \\
5.62 \\
7.06\end{array}$ & $\begin{array}{r}11.42 \\
6.09 \\
6.80\end{array}$ & $\begin{array}{l}9.82 \\
8.39 \\
9.33\end{array}$ \\
\hline Fever Brook till well & 8 & 4-03-84 & 7.7 & 6.43 & 12.10 & 10.17 & 7.43 & 12.47 & 13.13 \\
\hline $\begin{array}{l}\text { Fever Brook } \\
\text { Knault's well (till) }\end{array}$ & 9 & $4-10-84$ & 7.3 & 5.96 & 10.41 & 8.80 & 6.40 & 7.64 & 11.96 \\
\hline
\end{tabular}

(27 percent by molarity). The sulfate complex, $\mathrm{AlSO}_{4}{ }^{+}$, was a minor component in all water samples, and the molarity usually was several orders of magnitude less than that of total dissolved aluminum.

Aluminum-bearing minerals in the system $\mathrm{Al}_{2} \mathrm{O}_{3}-$ $\mathrm{SiO}_{2}-\mathrm{H}_{2} \mathrm{O}$, such as gibbsite and kaolinite, are weathering products of primary aluminosilicate minerals. Solubilities of these minerals in water reach a minimum near pH 6.4 and increase as pH decreases (Drever, 1988). In general, at any particular concentration of silica, the most stable aluminum silicate mineral is the mineral that has the lowest equilibrium concentration of aluminum. For streams in the Swift River and the Fever Brook Basins, in which the activity of silica is approximately $10^{-4}$, the activity of aluminum in equilibrium with kaolinite is less than that which would be in equilibrium with gibbsite, $\mathrm{Al}(\mathrm{OH})_{3}$ (fig. 16). For solution $\mathrm{pH}$ values from 5.1 to 6.8 at the outlet gaging stations, the theoretical activity of aluminum in equilibrium with kaolinite ranges from $10^{-7.0}(2.7 \mu \mathrm{g} / \mathrm{L})$ to $10^{-8.1}(0.2 \mu \mathrm{g} / \mathrm{L})$, respectively.

Aluminum activity in stream water and ground water generally was 10 to 100 times greater than the calculated theoretical activity at equilibrium with kaolinite and gibbsite; the activities of aluminum calculated for selected samples plot above the solubility lines of these minerals (fig. 16). Gibbsite and kaolinite were identified in some of the soil samples collected in the basins. However, the apparent supersaturation suggests that concentrations of aluminum may be controlled by 

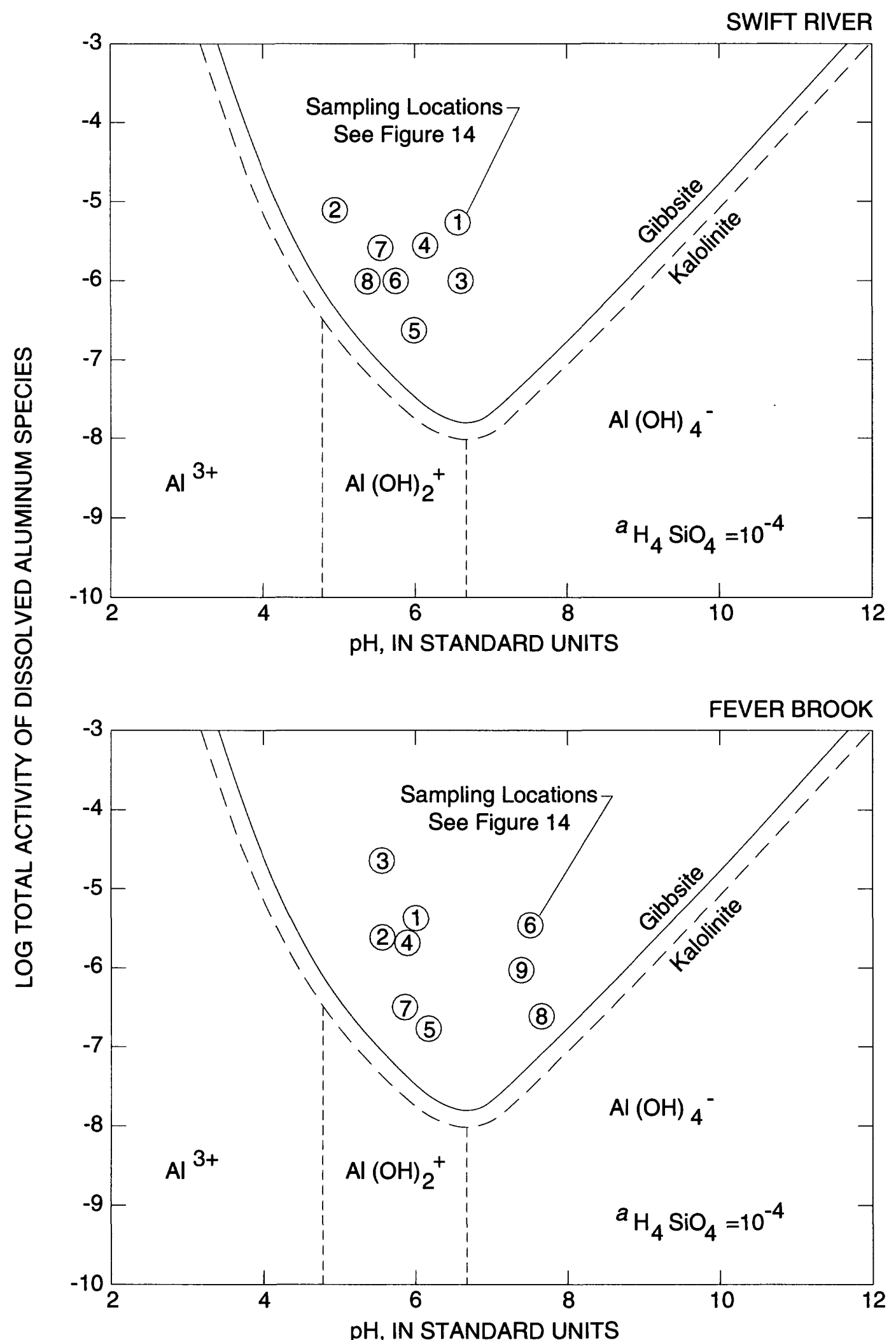

Figure 16. Composition of water and stability of dissolved aluminum species in equilibrium with gibbsite and kaolinite at 25 degrees Celsius, West Branch Swift River and East Branch Fever Brook Basins, central Massachusetts. (Modified from Drever. 1988.) 
minerals other than gibbsite and kaolinite, for example, cryptocrystalline phases of aluminum hydroxide (Jones and others, 1974). An alternate interpretation is that the solutions are in fact in equilibrium with crystalline gibbsite and kaolinite, but that the presence of colloidal or suspended aluminum, and (or) organically bound aluminum, caused an overestimation of aluminum concentrations.

When the infiltration capacity of the soil is exceeded during heavy storms or rapid snowmelt, the low-pH, high-aluminum soil water can be flushed rapidly from the soil zone. As this water mixes with stream water of higher $\mathrm{pH}$, precipitation of aluminum may be limited kinetically. A possible example of the resulting supersaturation with respect to gibbsite is the stream sample collected during the heavy rainstorm on May 30 , 1984 , at the tributary in the subbasin underlain by gabbro. The aluminum concentration was $110 \mu \mathrm{g} / \mathrm{L}$, much higher than the equilibrium concentration calculated for the relatively high $\mathrm{pH}(6.48)$ at the time of sampling. The supersaturation may be explained either by kinetic constraints on the precipitation reaction, or by the presence of increased polymeric or organicallybound aluminum in the filtered sample. More frequent sampling of soil water, ground water, and stream water during storm runoff and snowmelt would help to improve the understanding of the relation between aluminum geochemistry and hydrology.

\section{Biogeochemical Processes}

\section{Sulfate Mobility}

The mobility of sulfate in a basin that has surface and ground water of low ionic strength is an important factor in determining the sensitivity of that basin to acidic deposition. To maintain electrical charge balance, sulfate ions that are transported in solution must be accompanied by positively charged ions. These ions generally are base cations, important nutrients for plant growth. The availability of base cations for uptake by vegetation is directly affected by the fate of sulfate in the soil zone. Sulfate transport promotes transport of base cations from the soil, potentially causing a lack of nutrients for vegetation. If base cations are depleted from exchange sites faster than they are resupplied by weathering, hydrogen or aluminum becomes the cation that accompanies the sulfate, thus lowering the alkalinity of receiving waters. Streams and lakes in drainage basins with limited capacity to supply base cations are thought to acidify over periods of decades to centuries (National Acid Precipitation Assessment Program, 1983).

Sulfate sorption takes place primarily in the soil, where weathering of primary minerals to clays and metal oxides and hydroxides has generated sorption sites. Where sulfate is retained by sorption sites, basecation depletion from the soil is limited; where sulfate is not retained, and (or) sulfate is desorbed from sorption sites, base-cation depletion results as cations are removed to balance the anion charge. The potential for acidification is greatest in drainage basins with soils that have little capacity to adsorb sulfate or already are saturated with sulfate. At this stage, sulfate replaces bicarbonate as the dominant anion in solution, as documented in a forested drainage basin in the White Mountains of New Hampshire (Cronan, 1978). After correction for chloride from road salt, sulfate also is the dominant anion in the surface and ground waters in the Swift River and Fever Brook Basins.

The flux of sulfate in streamflow is the result of several sources and processes, and can be expressed as:

$$
S_{s}=S_{w d}+S_{d d} \pm S_{\mathrm{sp}} \pm S_{m w} \pm \mathrm{S}_{b p} \text {, }
$$

where

$S_{s}$ is sulfate in streamflow,

$S_{w d}$ is sulfate in wet deposition,

$S_{d d}$ is sulfate in dry deposition,

$S_{s p}$ is sulfate that is added or removed by sorption processes,

$S_{m w}$ is sulfate generated by mineral weathering and (or) consumed in precipitation reactions, and

$S_{b p}$ is sulfate generated or consumed by biological processes.

$S_{\mathrm{s}}$ was calculated from sulfate concentrations and stream discharge for each basin. $S_{w d}$ was calculated from measurements of sulfate concentrations and precipitation at the collection site in New Salem. $S_{\mathrm{dd}}, S_{s p}$, $S_{m w}$, and $S_{b p}$ were not directly measured, thus the quantities of sulfate that entered in dry deposition and sulfate that was cycled in each basin had to be indirectly evaluated.

A reliable, reproducible method for the measurement of $S_{d d}$ was not available during this study. However, some researchers have equated the dry 
deposition of sulfate to the net flux of sulfate if no other sources are present in the drainage basin (Likens and others, 1977; Katz and others, 1985; Peters, 1989a). $S_{d d}$ probably is the largest of the unknown terms. Dry deposition has been recognized as an important source of sulfate in many drainage basins (Brezonik and others, 1980; Kerr, 1981; Suarez and Jones, 1982; Lindberg and Garten, 1988). The particulate form of sulfur may be a neutral or acidic salt, whereas sulfur which enters as a gas, such as $\mathrm{SO}_{2}$, can oxidize and react with water to produce sulfuric acid. Sulfate is incorporated in wet deposition by washout (scavenging) or rain out (sulfatebearing particles provide nucleation centers for the formation of water droplets or snow flakes). Dry deposition of sulfur occurs through absorption by vegetation or settling on vegetation surfaces independently of rain. This sulfur eventually will be washed into the drainage basin but will not be accounted for in samples of wet deposition.

Sulfate export in stream water $\left(S_{s}\right)$ exceeded sulfate inputs in wet deposition $\left(S_{w d}\right)$ by 55 percent at Swift River and 23 percent at Fever Brook. If sulfate behaves conservatively, which is equivalent to the condition that $S_{m w}, S_{s p}$, and $S_{b p}$ are negligible, or $S_{d d}=S_{s}-S_{w d}$, then dry deposition accounted for 36 percent of the total sulfate deposition at Swift River and 19 percent of the total sulfate deposition at Fever Brook from December 1983 through August 1985 (calculated from table 8). This difference can not be attributed entirely to differences in dry deposition between the two basins, because of the geographic proximity of the basins and similar vegetation. The 36 percent dry deposition of sulfur calculated for Swift River is comparable to the dry deposition contribution estimated for the nearby Catskill Mountains in southern New York (P.S. Murdoch, U.S. Geological Survey, written commun., May 1985). However, the sulfate dry deposition estimate of 19 percent for Fever Brook probably is too low, calling into question the assumption that $S_{m w}, S_{s p}$, and $S_{b p}$ are negligible. From these results, a sink for sulfate appears to be present in Fever Brook.

The total (salt-corrected) flux of sulfate from the Fever Brook Basin (1,333 eq/ha, table 8) was 79 percent of sulfate flux from the Swift River Basin (1,684 eq/ha). This difference in sulfate flux between the two basins may be attributed to differences in water flux, as well as factors affecting $S_{m w}, S_{s p}$, and $S_{b p}$. Water flux can significantly affect sulfate flux (Shaffer and Galloway,
1982; Shanley, 1989; Huntington and others, 1994). The runoff from Fever Brook (1,034 mm) was only 86 percent of the runoff from Swift River $(1,200 \mathrm{~mm})$, and thus may account for most of the difference in the net flux of sulfate.

If water flux accounts for most of the difference in sulfate flux, the additional sulfate retained in Fever Brook would be as $S_{s p}$. This pool of sorbed sulfate is labile and will be mobilized given sufficiently high soil moisture. An additional amount of sulfate at Fever Brook probably was consumed by sulfate reduction, which would be represented in equation (18) as a negative term $S_{b p}$. Decreases in sulfate during the summer at Fever Brook (fig. 10), while sulfate concentrations at Swift River remained constant (fig. 9), indicate that sulfate reduction may be an important process. Sulfate concentrations at the three ground-water sites in the Fever Brook Basin were significantly higher than sulfate concentrations at the four ground-water sites in the Swift River Basin (table 4), an indication that there may be contributions of sulfate, $S_{m w}$, from the weathering of sulfides. A positive $S_{m w}$ term would increase $S_{s}$, whereas sulfate reduction would decrease $S_{s}$. Sulfide weathering and sulfate reduction each may be significant processes at Fever Brook, and both are discussed briefly below.

The weathering of sulfide minerals such as pyrite and pyrrhotite may contribute to the sulfate flux from the drainage basins. These minerals are present in the sulfidic schist contained in the Rangely Formation, which underlies parts of both basins. This formation is areally more extensive in the Fever Brook Basin. Two ground-water sites in the Fever Brook Basin have sulfate concentrations much greater than $200 \mu \mathrm{eq} / \mathrm{L}$ (table 4), well in excess of the amount that would be expected from precipitation and evapotranspiration. Parnell (1983) identified pickeringite, a highly soluble aluminum sulfate mineral, in powdery surface encrustations at a nearby outcrop of the Partridge Formation. Weathering of sulfide minerals in the formation are the likely source of sulfate for the formation of this secondary mineral.

The extensive wetlands in the Fever Brook drainage basin provide an environment favorable to sulfate reduction. Evidence for sulfate reduction is given by the pattern of sulfate concentrations in the two basins from June to November 1984. During this period, discharge decreased in both basins during a period of less than average precipitation. At Swift River, alkalinity 
increased during this period, whereas sulfate concentrations remained constant or increased only slightly (fig. 9). At Fever Brook, alkalinity increased but sulfate concentrations decreased during the period. Loss of sulfate by reduction appeared to contribute to the alkalinity increase at Fever Brook; alkalinity and sulfate concentration were negatively correlated at Fever Brook and positively correlated at Swift River during June to October 1984 (fig. 17). A concurrent increase in the concentration of DOC in Fever Brook (fig. 10) is consistent with favorable conditions for sulfate reduction. Additionally, hydrogen sulfide gas was usually detected at the Fever Brook sand and gravel well, located near a marshy area. These conditions indicate that sulfate was being reduced by bacteria in the impoundments and swampy areas. In the bacterially mediated sulfate reduction reaction, sulfate is reduced, whereas organic matter $\left(\mathrm{CH}_{2} \mathrm{O}\right)$ is oxidized (Monahan, 1984$)$ as follows:

$$
\mathrm{SO}_{4}^{2-}+2 \mathrm{CH}_{2} \mathrm{O}+2 \mathrm{H}^{+}=\mathrm{H}_{2} \mathrm{~S}+2 \mathrm{CO}_{2}+2 \mathrm{H}_{2} \mathrm{O} \text {. }
$$

Although sulfate reduction apparently was the most important during the summer and autumn of 1984, it may proceed at slower rates and affect the sulfate concentration and flux (Ss) during other periods as well.

\section{Retention of Hydrogen and Nitrate}

Most of the hydrogen ion and nitrate that entered in wet deposition were retained by both basins. Hydrogen ion was removed by weathering and cation-exchange reactions, and nitrate was taken up as a nutrient by vegetation. Short-lived increases in the concentration of hydrogen ion and nitrate in the streams were observed after large hydrologic inputs, such as storms or rapid snowmelt. During these events, normal flow paths were short-circuited, and the resulting limited soil contact time precluded significant removal of hydrogen ion and nitrate from solution. Using net-flux data (table 8) and estimating ammonium flux from data at nearby Bickford Reservoir drainage basin (Hemond and Eshleman, 1984), the processes by which chemical solutes are generated and consumed in the drainage basins can be

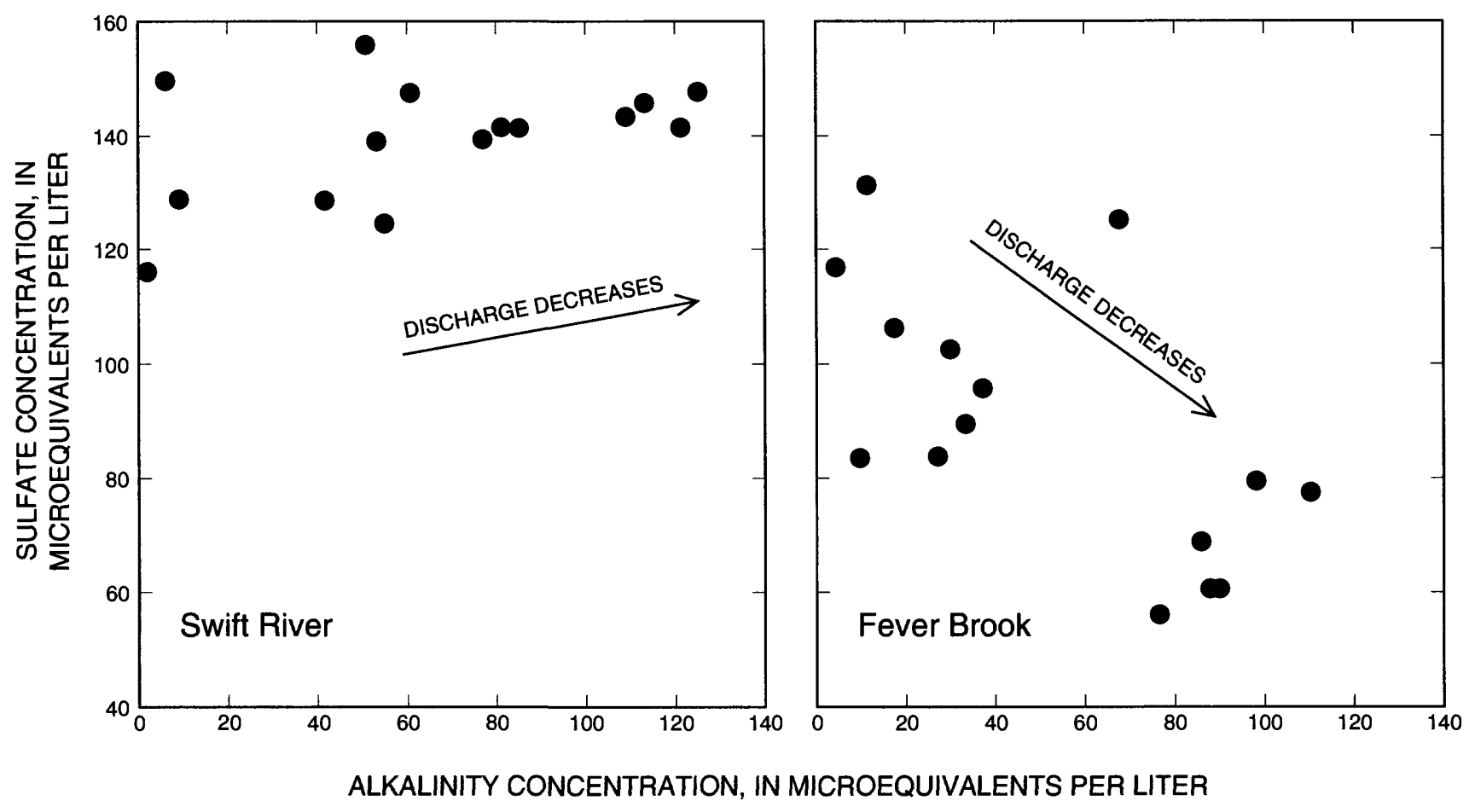

Figure 17. Relations between sulfate and alkalinity concentrations in West Branch Swift River and East Branch Fever Brook, central Massachusetts, June through October 1984. 
quantified. The net result of these processes is constrained by the following charge-balance equation, derived from rearranging the alkalinity equation:

$$
\begin{aligned}
& 2\left[\mathrm{Ca}^{2+}\right]+2\left[\mathrm{Mg}^{2+}\right]+\left[\mathrm{Na}^{+}\right]+\left[\mathrm{K}^{+}\right]-\left[\mathrm{NO}_{3}^{-}\right] \\
= & 2\left[\mathrm{SO}_{4}^{2-}\right]+\left[\mathrm{HCO}^{-}\right]-\left(\left[\mathrm{H}^{+}\right]-\left[\mathrm{NH}_{4}^{+}\right]\right)
\end{aligned}
$$

The left side of the equation represents the products of mineral-weathering reactions that produce base cations, and the retention of nitrate. The right side of the equation balances those reactions with export of sulfate and bicarbonate alkalinity, and consumption of hydrogen and ammonium (fig. 18). Negligible amounts of carbonate $\mathrm{CO}_{3}{ }^{2-}$ and hydroxide $\left(\mathrm{OH}^{-}\right)$are present at the ranges of $\mathrm{pH}$ in the basins, and thus are not shown in the equation. Nitrate retention could account for 43 percent of hydrogen consumption in each drainage basin (table 8), an indication of the effectiveness with which these drainage basins buffer inputs of nitric acid.

\section{Application of Deicing Salts}

The significant effect of deicing salt application on water quality in Swift River and Fever Brook Basins was unexpected. Based on total ionic equivalents for the period of study (table 8), deicing salts increased the total ionic output flux by 41 percent at Swift River and 120 percent at Fever Brook. Although nearly all salt was applied during a 4-month period in winter, seasonal trends of sodium and chloride concentrations in streamflow were not pronounced. At Fever Brook, elevated concentrations persisted throughout the year, implying that the salt reached the saturated zone and was continually released to the stream by ground-water discharge. At Swift River, sodium concentrations varied similarly to the other cations, indicating that the seasonal input of deicing salt was primarily incorporated in the annual ground-water recharge from which it was supplied to surface water in a relatively uniform manner throughout the year. At Swift River, the significant correlation between sodium concentration and discharge was not masked by sodium from deicing salts.

Several researchers have investigated the effect of deicing salts on water quality. Oberts (1986) found that many pollutants were released from sand and salt applied to Minnesota highways. Kunkle (1972) examined the movement of salt-contaminated ground water generated by runoff from a highway in Vermont. Wilcox
(1986) investigated the effects of leachate from a deicing salt storage pile and runoff from a salted Interstate highway on water chemistry in a peat bog in Indiana. Known adverse environmental effects of road salting include elevated sodium and chloride concentrations in water-supply wells (Huling and Hollocher, 1972), injury to roadside vegetation (Scharpf and Srago, 1974), and alterations to the ecology of wetlands (Wilcox, 1986). An additional effect determined in this study is the potential of deicing salts, through ion exchange, to accelerate the leaching of calcium and magnesium from soils, thus increasing the adverse effect of acid deposition by undermining soil fertility.

At Fever Brook, ion exchange was an important factor in the overall effect of deicing salts on water chemistry. Sodium in road salt replaced calcium and magnesium on exchange sites. As a result, the output flux of calcium increased by 75 percent and the output flux of magnesium increased by 61 percent (see below). A minor part of these increases was caused by small amounts of calcium and magnesium impurities in the deicing salts; most was caused by ion exchange. Few studies, however, have specifically addressed the process of ion exchange in interpreting the effects of deicing salts on water chemistry. Kunkle (1972) alludes to the possibility of ion exchange in the Vermont stream study. Wilcox (1986) discusses ion exchange in the study of the Indiana peat bog, but does not propose it as a mechanism to explain the measured increases in base cations greater than background concentrations, and the excess of chloride over sodium at many of the sampling sites. Ion exchange of sodium for calcium and magnesium would in fact be entirely consistent with his observations.

\section{Adjustment of Chemical Fluxes}

Both drainage basins contained road sections that were treated with deicing salts. At Fever Brook, in particular, these salts were the dominant source of solute load in the stream. Therefore, to understand the processes controlling stream-water geochemistry in these basins, the contribution of the deicing salts to the chemical load of the streams needs to be quantified.

Common deicing salt is predominantly sodium chloride, with varying but generally minor amounts of calcium chloride, magnesium chloride, and calcium sulfate. Other workers (Katz and others, 1985; Yuretich 


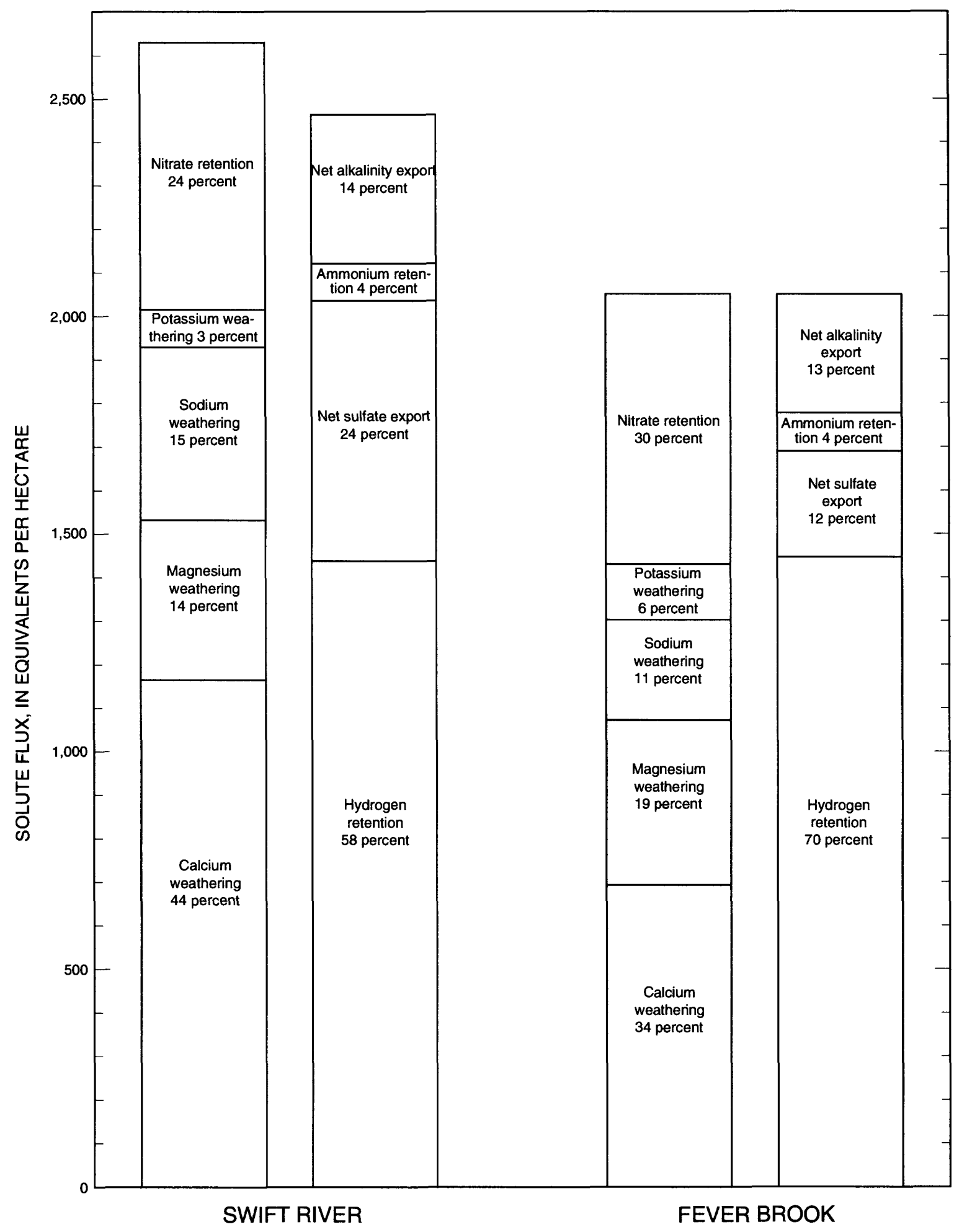

Figure 18. Charge balance for solute fluxes from the West Branch Swift River and East Branch Fever Brook Basins, central Massachusetts, December 1983 through August 1985. The left column for each site includes cations that had a net export (output in streamflow greater than input in precipitation) and anions that had a net retention; the right column includes anions that had a net export and cations that had a net retention. 
and Batchelder, 1988) have made corrections for deicing salt based on the assumption that the chloride in stream water in excess of that accounted for by precipitation was balanced by cations in the ratio that they are present in the salt (sulfate impurities generally have been ignored). A drawback to this approach is that ionexchange reactions may alter the relative proportion of cations that balance the chloride (Kunkle, 1972). This is the well-known salt effect, which has been shown to cause episodic acidification in areas of thin, acidic soils in Norway. The salt effect is the process whereby sodium in precipitation exchanges for hydrogen ion on soil-exchange sites (Wiklander, 1975; Wright and others, 1988). In soils with higher base saturation, the salt effect is more likely to be reflected in the exchange of sodium for calcium and magnesium. Thus, flux corrections for deicing salts that fail to account for exchange reactions may underestimate the natural sodium export and overestimate the natural calcium and magnesium export.

If the net chloride export in the Fever Brook Basin is assumed to be derived from deicing salt, and if the cations associated with net chloride export are apportioned based on the stoichiometry of the salt composition, it is readily seen that all of the exported sodium is required to match the chloride export (table 7). This calculation implies that sodium from weathering sources is negligible, a condition that is inconsistent with the presence of sodic-rich plagioclase in the schist of the Rangely Formation, which underlies a large part of the basin (Knapp, 1990). Weathering of plagioclase should supply an amount of sodium to stream water such that the total sodium flux is considerably greater than the sodium from deicing salt alone. Because sodium export approximately balances chloride export, there must be a sink for sodium or, alternatively, an additional source of chloride.

Possible additional sources of chloride include a chloride-bearing mineral, or a net release of chloride from storage. Fever Brook Basin contains considerable amounts of hornblende and biotite, both potential sources of chloride. Microprobe analyses of hornblende from various formations in the north Quabbin area show chloride concentrations on the order of 0.01 percent (Peter Robinson, University of Massachusetts, oral commun., 1990), far too little to be of significance to stream chemistry. Analyses of biotite were not available, but biotite is less easily weathered and is less likely to contain significant amounts of chloride, thus it likewise is discounted as a source of chloride. Net release of chloride from storage is feasible in a wet year, such as the first year of the study, but net release is unlikely given that the two years prior to the study also had greater than average flow for nearby streams (Gadoury and others, 1984, 1985). Given the apparent lack of a chloride source, there must be a sodium sink; this sink is postulated to be the soil cation-exchange complex.

Quantitative accounting of ion exchange is difficult because it is a function of the ionic composition of the runoff, the cation populations on soil-exchange sites, flow path of the runoff, and antecedent soil moisture conditions, all of which vary in space and time. Consider sodium and calcium, the major ions involved in ion-exchange reactions; if ion exchange is the dominant control on stream chemistry, and all other factors were constant, the sodium:calcium ratio in stream water would not vary. In Fever Brook, however, the sodium: calcium ratio ranges from 1 to 3.5 (equivalent basis). Furthermore, variations in the sodium:calcium ratio are not linked to season or flow regime.

The pattern of variation in base-cation concentrations at Fever Brook suggests that ion exchange has a greater short-term effect on base-cation concentrations than that of weathering. Sodium, calcium, and magnesium each have temporally similar patterns of variation in concentration that are at variance with the pattern observed for silica (fig. 10). If base-cation concentrations are directly controlled by weathering, variations in base-cation concentrations should track variations in silica concentrations. Although uptake of silica by diatoms may complicate this interpretation, cation exchange clearly affects the flux of sodium from applied deicing salt. Therefore, a method was developed to quantify the exchange and derive the background cation fluxes, or those fluxes that would be observed in the absence of deicing-salt application.

At Fever Brook, the first step in the salt correction was the usual assumption that the chloride flux in excess of that from precipitation was due to deicing salts. An independent estimate was then made of the sodium flux from weathering. The chloride excess was balanced by (1) the sodium remaining after adjustment for the estimated amount of sodium from weathering, (2) the minor amounts of calcium and magnesium in deicing salts, and (3) calcium and magnesium from ion 
exchange. The amounts of calcium and magnesium derived from deicing salt and ion exchange were subtracted from the total fluxes to yield the background fluxes. Also an adjustment was made for the small amount of sulfate in deicing salt. All adjustments were made on a monthly time step.

The estimate of the sodium flux from weathering was based on the stoichiometric relation between sodium and silica in ground water. At the three groundwater-sampling sites in the Fever Brook Basin, the sodium:silica ratio ranged from 0.25 to 0.51 . Three of 11 samples from the till well (fig. 5, well No. 422906072124301) had sodium:silica ratios greater than 0.8 , apparently affected by salt, and were not used in the analysis. The remaining eight samples from this well had sodium:silica ratios intermediate between those of the other two wells sampled. In the adjacent Carter and Mundberry Basins, which are underlain by the same geologic formations as Fever Brook Basin, samples from 10 wells had sodium:silica ratios near 0.5 , and in no case greater than 1.0 (Knapp, 1990). By contrast, samples from another well in the Carter Basin, near a road treated with deicing salt, had sodium:silica ratios between 1 and 2 . Ground water in this well was apparently contaminated with deicing salt, thus this site was not considered in the analysis. All analyses from the 10 wells at Carter and Mundberry Basins and the three wells at the Fever Brook Basin were combined; the overall mean sodium:silica ratio (molar basis) was $0.534 \pm 0.112$ (the range represents one standard deviation on either side of the mean). All silica in the stream was assumed to be derived from weathering, and thus the sodium flux from weathering was calculated from the mean sodium:silica ratio, applied to the monthly silica fluxes in the stream.

Monthly chloride fluxes were then adjusted for chloride in precipitation using the overall ratio of chloride load in precipitation to chloride load in the stream using totals from the study period. The adjustment was made as follows:

$$
\mathrm{Cl}_{\text {net }}=\mathrm{Cl}_{\text {stream }} \times F,
$$

where $\quad F=\left(\mathrm{Cl}_{\text {stream }}-\mathrm{Cl}_{\mathrm{ppt}}\right) / \mathrm{Cl}_{\text {stream }}$,

For Fever Brook, $F=0.923$.

The net monthly chloride flux was balanced by five components:

$$
\mathrm{Cl}_{\text {net }}=\mathrm{Na}_{\text {salt }}+\mathrm{Ca}_{\text {salt }}+\mathrm{Mg}_{\text {salt }}+\mathrm{Ca}_{\text {ex }}+\mathrm{Mg}_{\text {ex }} \text {, }
$$

where the subscript "salt" denotes a source in the deicing salt and the subscript "ex" denotes a source in the soil-exchange complex. $\mathrm{Na}_{\text {salt }}$ represents the amount of the sodium from applied deicing salts that was not retained by ion-exchange reactions. It is calculated by deducting the sodium flux from weathering from the total sodium flux:

$$
\mathrm{Na}_{\text {salt }}=\mathrm{Na}_{\text {stream }}-\mathrm{Na}_{\text {weathering }} \text {. }
$$

Direct inputs of calcium and magnesium to stream water from the dissolution of deicing salt $\left(\mathrm{Ca}_{\text {salt }}\right.$ and $\mathrm{Mg}_{\text {salt }}$ ) were calculated from $\mathrm{Cl}_{\text {net }}$ on the basis of the relative proportions of $\mathrm{Ca}$ and $\mathrm{Mg}$ in the composition of the applied salt (table 11), including applied $\mathrm{CaCl}_{2}$ (see below):

$$
\begin{aligned}
& \mathrm{Ca}_{\text {salt }}=\mathrm{Cl}_{\text {net }} \times 0.0365, \\
& \mathrm{Mg}_{\text {salt }}=\mathrm{Cl}_{\text {net }} \times 0.0062 .
\end{aligned}
$$

Table 11. Composition of rock salt applied in West Branch Swift River and East Branch Fever Brook Basins, central Massachusetts

[Percentages may not add to 100 percent due to rounding]

Percentage of composition

Compounds

\section{By Weight}

Sodium chloride $(\mathrm{NaCl})$ 97.0

Calcium chloride $\left(\mathrm{CaCl}_{2}\right)$

Magnesium chloride $\left(\mathrm{MgCl}_{2}\right)$ 5

Calcium sulfate $\left(\mathrm{CaSO}_{4}\right)$

$\underline{\text { Cations }}$

By Equivalents

Sodium $\left(\mathrm{Na}^{+}\right)$. 97.1

Calcium $\left(\mathrm{Ca}^{2+}\right)$

Magnesium $\left(\mathrm{Mg}^{2+}\right)$

Anions

Chloride $\left(\mathrm{Cl}^{-}\right)$.

Sulfate $\left(\mathrm{SO}_{4}^{2-}\right)$ 
Inputs of calcium and magnesium to stream water from ion exchange were calculated from the residual chloride not balanced by the cations in deicing salt. The sum $\left(\mathrm{Ca}_{\mathrm{ex}}+\mathrm{Mg}_{\mathrm{ex}}\right)$ was calculated from equation 17 . The individual quantities $\mathrm{Ca}_{\mathrm{ex}}$ and $\mathrm{Mg}_{\mathrm{ex}}$ were calculated based on the assumption that calcium and magnesium are released from exchange sites in the same relative proportion that they appear in stream loads for each month, as follows:

$$
\begin{gathered}
\mathrm{Ca}_{\mathrm{ex}}=\left(\mathrm{Ca}_{\mathrm{ex}}+\mathrm{Mg}_{\mathrm{ex}}\right) \times\left(\mathrm{Ca}_{\text {stream }} /\left(\mathrm{Ca}_{\text {stream }}+\right.\right. \\
\left.\left.\mathrm{Mg}_{\text {stream }}\right)\right), \\
\mathrm{Mg}_{\mathrm{ex}}=\left(\mathrm{Ca}_{\mathrm{ex}}+\mathrm{Mg}_{\mathrm{ex}}\right) \times\left(\mathrm{Mg}_{\text {stream }} /\left(\mathrm{Ca}_{\text {stream }}+\right.\right. \\
\left.\left.\mathrm{Mg}_{\text {stream }}\right)\right) .
\end{gathered}
$$

Thus, the background net flux of sodium reported (table 8) was that of the estimated weathering flux; background fluxes of calcium and magnesium were calculated as the actual measured flux minus the flux from exchange and the minor deicing salt contributions. An upper and lower bound for the sodium contribution was estimated using the standard deviation of the sodium: silica ratio, and upper and lower bounds on the calcium and magnesium fluxes were calculated accordingly (table 8 ). Note that an increase in the sodium assigned to weathering requires an increase in calcium and magnesium from ion exchange, and a resulting decrease in the calculated background flux of calcium and magnesium. Sulfate was assumed to be conservative and also was adjusted based on its content in salt and the excess chloride flux.

At Swift River, deicing salts had a less important role in stream chemistry; application rates per unit area were lower and natural flux of sodium was higher. Thus, deicing salt corrections thus were made in the conventional manner (table 8 ). Excess chloride $\left(\mathrm{Cl}_{\text {stream }}-\mathrm{Cl}_{\mathrm{ppt}}\right)$ simply was balanced by cations in the ratio that they occur in the deicing salts. Cation ratios were somewhat different at Swift River because of the higher percentage of calcium chloride in the applied salt (see below). Sulfate flux was corrected in like manner. Corrections were made on total fluxes for each water year.

\section{Comparison of Calculated Salt Export and Salt- Application Data}

The estimated total salt application calculated from the excess chloride was checked against the salt application records for the State and town highways in the basins. If all applied salt reached the stream, the amounts should agree. However, errors may arise because the application records are not broken down to the small scale of the basins in this study, and because the salting activity of both State and town must be considered. Nonetheless, a general agreement of the amounts would assure that no gross errors have been made, such as failing to identify a major internal source of chloride.

Salt-application data were obtained from the Massachusetts Department of Public Works, which maintains State Routes 202 and 122 through the Swift River and Fever Brook Basins, respectively (table 12). Also, the Swift River Basin includes parts of the towns of Wendell, Shutesbury, and New Salem, all of which maintain town roads in the basin. Of those roads, however, only a part of Louck's Pond Road in Shutesbury is salted. Fever Brook Basin is entirely within the town of Petersham, where West Road and State Route 32A are salted by the town. State salt-application records were available on tonnage of rock salt and calcium chloride applied per winter per lane mile for maintenance areas that included the road segments of interest. A lane mile

Table 12. Deicing salt-application data, West Branch Swift River and East Branch Fever Brook Basins, central Massachusetts

[All values in megagrams]

\begin{tabular}{cccccr}
\hline \multirow{2}{*}{ Salt type } & \multicolumn{2}{c}{ Swift River } & & \multicolumn{2}{c}{ Fever Brook } \\
\cline { 2 - 3 } \cline { 5 - 6 } & $1983-84$ & $1984-85$ & & $1983-84$ & $1984-85$ \\
\hline Town-rock salt & 2.01 & 2.01 & & 4.88 & 5.00 \\
State-rock salt & 70.57 & 49.55 & & 109.36 & 106.84 \\
$\begin{array}{c}\text { State-calcium } \\
\text { chloride }\left(\mathrm{CaCl}_{2}\right)\end{array}$ & 1.79 & 1.87 & & 1.53 & 1.53 \\
\hline
\end{tabular}


Table 13. Chloride load in applied deicing salt and net chloride flux from West Branch Swift River and East Branch Fever Brook Basins, December 1983 through August 1985, central

Massachusetts

[All values, except percent, in equivalents per hectare]

\begin{tabular}{cccccc}
\hline Basin & $\begin{array}{c}\text { Chloride input } \\
\text { (precipitation) }\end{array}$ & $\begin{array}{c}\text { Chloride output } \\
\text { (stream) }\end{array}$ & $\begin{array}{c}\text { Chloride flux } \\
\text { (net) }\end{array}$ & $\begin{array}{c}\text { Chloride load in } \\
\text { applied deicing salt }\end{array}$ & $\begin{array}{c}\text { Percentage of deicing } \\
\text { salt exported in } \\
\text { streamflow }\end{array}$ \\
\hline $\begin{array}{l}\text { West Branch } \\
\text { Swift River............. } 184\end{array}$ & 1,132 & 948 & 655 & 145 \\
$\begin{array}{l}\text { East Branch } \\
\text { Fever Brook ............. 184 } 184\end{array}$ & 2,397 & 2,213 & 3,078 & 72 \\
\hline
\end{tabular}

is defined as a mile of paved roadway $12 \mathrm{ft}$ wide; thus a 1-mile section of two-lane highway with paved shoulders and an entire paved width of $36 \mathrm{ft}$ has 3 lane miles. For each basin, the roadway segment of interest represented about 5 percent of the roadway in the corresponding maintenance area. Salt application was assumed to be uniform, and the tonnage of applied salt was prorated according to the number of lane miles of State road in each basin. A chemical analysis of the rock salt was obtained from the supplier, and the calcium chloride, which was used in minor amounts, was assumed to be pure. Calculations were made in a similar manner for the town roads; the estimate of the total amount of salt applied was prorated for the fraction of town road in the basins relative to the total amount of town road salted. Rock-salt composition again was obtained from the supplier. Salt application by the towns was minor relative to amounts applied by the State.

On the basis of net chloride flux, salt export from Fever Brook Basin was slightly more than two-thirds of the amount applied, whereas salt export from Swift River Basin was 45 percent more than the amount applied (table 13). Although the discrepancies between applied and transported salt appear large, the discrepancies probably are within the error introduced by the assumption of uniform salt-application rates. Differences in salt-application history probably do not account for the discrepancies, because in each basin, the annual salt application during the 2-year study period was nearly exactly average for the $1975-85$ period (Sam Pollock, Massachusetts Department of Public Works, written commun., 1990). The higher percentage of wetlands at Fever Brook relative to Swift River Basin may attenuate annual variations in the chloride flux through longer water residence times. Cherkauer (1977) found that deicing salts in runoff were stored in impoundments, attenuating salt loads in spring runoff and releasing salt to runoff during summer storms. The net salt retention at Fever Brook thus may reflect a net loss of salt to storage following the unusually low salt application in the winter of 1982-83. Although there was about the same amount of salted roadway in each basin, the effect of salting is greater in Fever Brook because it has less than one-half the drainage area and approximately double the salt-application rate of Swift River. The calculated retention at Fever Brook may be within the error of the calculated application amounts.

\section{ACIDIFICATION STATUS OF THE BASINS}

The acidification status of Swift River and Fever Brook was explored by use of an approach developed by Henriksen (1980) and modified by Dillon and others (1980). Henriksen defined acidification as the quantitative difference between historic and present-day alkalinity. On the basis of the chemistry of pristine freshwaters sampled throughout the world, Henriksen observed that the sum of the major weathering base cations, predominantly calcium and magnesium, virtually equaled alkalinity. This relation results if carbonic acid is the primary agent in mineral-weathering reactions; one equivalent of bicarbonate and one equivalent of base cations are yielded to solution for each mole of carbonic acid consumed in the reaction. Thus, Henriksen estimated historic alkalinity to be the sum of equivalents of calcium and magnesium and he attributed this amount to mineral weathering by carbonic acid. Using this approach, one can infer the effect of sulfuric acid in weathering reactions by the deviation from the idealized 
one-to-one relation of stream alkalinity to base cations. The addition of sulfuric acid can cause one of two chemical responses in a drainage basin. One response may be that sulfuric acid increases the rate of weathering simply by adding to the amount of weathering by carbonic acid. One equivalent of sulfuric acid will react to produce one equivalent of base cations in solution, and transport of base cations would be increased onefor-one relative to an original level. For example, consider an unaffected drainage basin in which the annual net flux of base cations of 100 eq (equivalents), balanced by a net flux of 100 eq of alkalinity. If 50 eq of sulfuric acid are introduced and reacted in the system, the net flux of base cations would be $150 \mathrm{eq}$, alkalinity would still be $100 \mathrm{eq}$, and the net flux of sulfate would be 50 eq. This appears to be occurring in many drainage basins, though commonly the source of base cations may be the ion-exchange complex rather than mineral weathering. A second response of a drainage basin may be that sulfuric acid does not increase the rate of mineral weathering. Minerals are dissolved by carbonic acid, which yields cations and bicarbonate to the water. The sulfuric acid does not cause weathering, but it reacts with and neutralizes the alkalinity. The result is decreased alkalinity. For example, in the system just described, 100 eq of base cations and 100 eq of alkalinity would be produced by weathering with 100 eq of carbonic acid. The 50 eq of added sulfuric acid would neutralize $50 \mathrm{eq}$ of alkalinity so that alkalinity would decrease from 100 to 50 eq. Net export would be $100 \mathrm{eq}$ of base cations, and 50 eq each of alkalinity and sulfate.

Consistent with the observations of Henriksen (1980), calcium and magnesium were the major cations produced by weathering at Swift River and Fever Brook Basins. Plots of the relations among calcium, magnesium, alkalinity, and sulfate at Swift River and Fever Brook illustrate Henriksen's theory (fig. 19). The theoretical concentrations resulting from simple carbonic acid weathering is illustrated by a one-to-one relation between alkalinity and calcium plus magnesium (figs. $19 A$ and $19 B$ ). In each basin, all stream samples plot below the theoretical carbonic acid weathering line, an indication of the deficit of alkalinity relative to weathering base cations. A second set of plots (fig. 19C and $19 D$ ) incorporate the concept of stream sulfate as a balancing anion (Dillon and others, 1980). There was a shift in the plot toward the theoretical weathering line (figs. 19C and 19D) when sulfate concentrations were included in the chemical balance.

Assuming that the rate of transport of base cations measured during this study is equal to the rate before acid deposition, then mineral acids entering the basins in wet and dry deposition are reacting with and consuming alkalinity. This condition would imply that the streams are showing signs of acidification. If, however, alkalinity has remained constant through time, then sulfuric acid inputs have increased the rate of weathering (or the rate of depletion of base saturation) in the drainage basins. At Swift River and Fever Brook, calcium and magnesium concentrations are balanced by alkalinity and sulfate, but this does not indicate whether the rate of weathering has increased or whether alkalinity has been consumed by sulfuric acid.

The chemical budget of solutes entering a basin as wet deposition and leaving by streamflow is useful in interpreting drainage basin interactions that may affect the degree of acidification in a drainage basin. The net fluxes of chemical solutes can be used graphically to depict a mass balance of the sources of alkalinity and acidity (Eshleman and Hemond, 1985). Terms in the alkalinity equation (eq. 15) are quantified in a vertical bar graph (fig. 18). Sources of alkalinity, which are primarily weathering reactions, are shown as the left bar of each pair; sources of acidity are to the right. Ideally, if all ionic species were measured without error, the heights of the alkalinity and acidity flux bars would be the same. The slight differences noted may be attributed to organic acid anions, which were not measured.

Sulfuric acid from precipitation clearly is a major factor in the chemical quality of the streams. Net transport of sulfate in the Swift River Basin could account for as much as 33 percent of the transport of base cations derived from weathering, including calcium, magnesium, sodium, and potassium. Reduction of sulfate in the Fever Brook Basin may mask the full extent that sulfuric acid affects base-cation transport in that drainage basin. On the basis of net flux, as much as 17 percent of base-cation transport may be associated with sulfate flux in Fever Brook. 

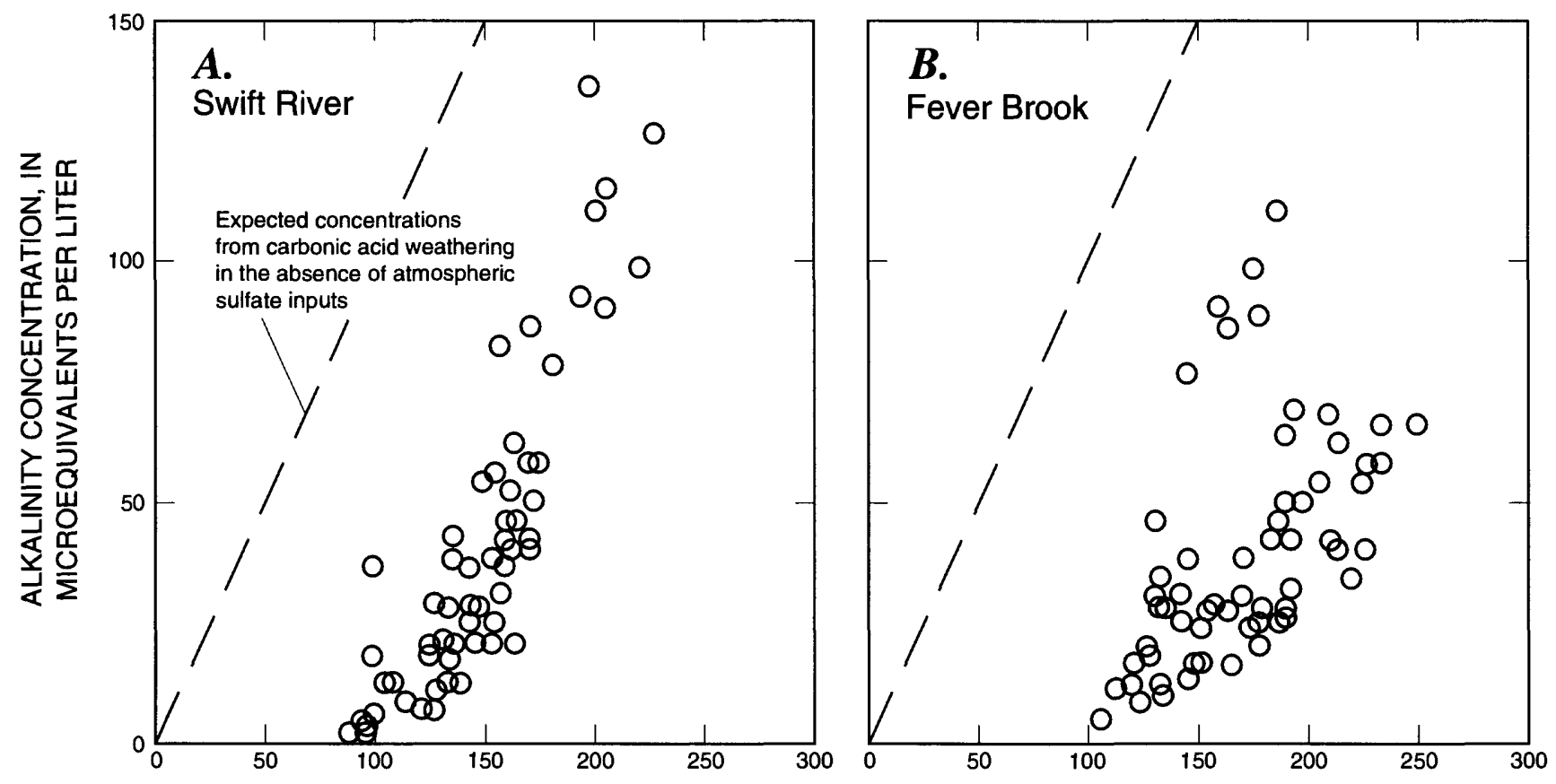

CALCIUM PLUS MAGNESIUM CONCENTRATION, IN MICROEQUIVALENTS PER LITER
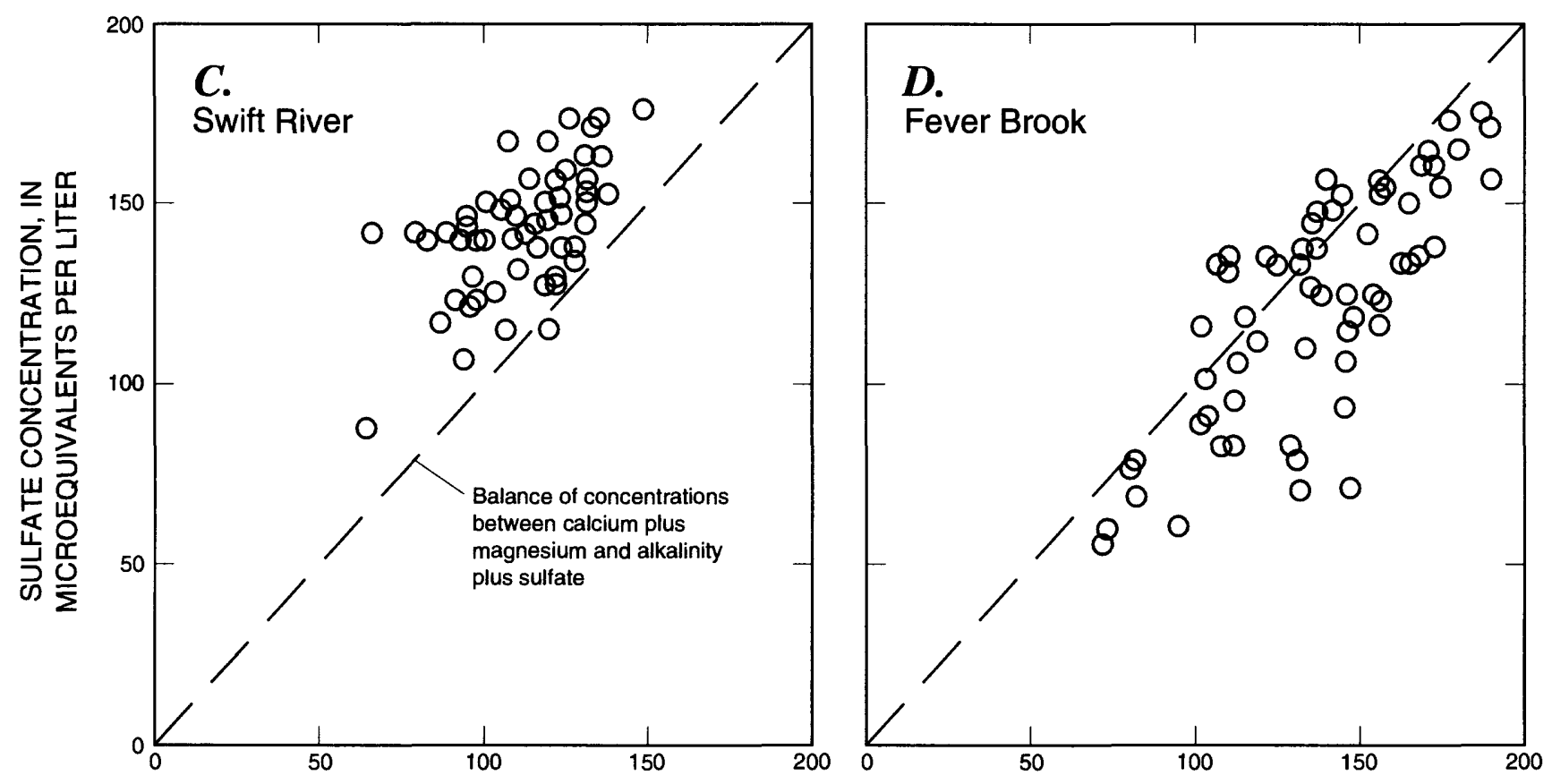

CALCIUM PLUS MAGNESIUM-ALKALINITY CONCENTRATION, IN MICROEQUIVALENTS PER LITER

Figure 19. Relations between calcium plus magnesium concentrations and major anion solutes in stream water in the West Branch Swift River and East Branch Fever Brook, central Massachusetts. 


\section{SUMMARY AND CONCLUSIONS}

In cooperation with the Metropolitan District Commission and the Massachusetts Department of Environmental Protection, the U.S. Geological Survey conducted an investigation in the Quabbin Reservoir Basin from December 1983 through August 1985. The purpose of the study was to determine the processes that affect water quality and solute fluxes in two inlet streams to the reservoir-the major water source for metropolitan Boston. In the Swift River and Fever Brook Basins, measurements were made of streamflow and precipitation quantity and quality as well as ground-water quality. Data from these measurements were interpreted to assess the effect of acid precipitation, road salting, basin hydrology, sulfate adsorption, aluminum geochemistry, and other factors on streamwater quality and solute fluxes. The scientific findings of the study are intended to help guide water-resources management of the drainage basin, such that the high water quality in the Quabbin Reservoir is maintained.

Processes in the Swift River and Fever Brook Basins, central Massachusetts, neutralized inputs of dilute sulfuric and nitric acids in precipitation to a moderately buffered solution enriched in base cations and silica in stream water. Inputs of hydrogen ion and nitrate in precipitation were nearly completely retained in both basins. The most likely causes for this retention are assimilation of nitrate by the biota, and exchange of hydrogen ion for base cations in the soil. In contrast, each basin had a net export of sulfate relative to inputs in wet deposition. At Swift River, sulfate export exceeded the input of sulfate in wet deposition by 63 percent. This percentage is near the amount typically attributed to dry deposition of sulfate in the northeastern United States; thus, sulfate outputs were in approximate balance with inputs. The sulfate adsorption capacity of the soils in Swift River appears to be saturated. At Fever Brook, sulfate export was 29 percent greater than inputs in wet deposition. Accounting for dry deposition, there probably was some net retention of sulfate in the basin. Sulfate retention at Fever Brook was attributed to sulfate reduction in the wetland areas. In both basins, export of base cations, derived from mineral weathering and ion-exchange processes, greatly exceeded inputs in atmospheric deposition. Somewhat more alkalinity was produced in the Swift River Basin from higher weathering rates, but this was approximately matched at Fever Brook Basin by sulfate reduction, so that alkalinity was about the same in each basin.

The different chemical responses in the Swift River and Fever Brook Basins were caused, in part, by differences in hydrology. Of the two streams, Swift River responded more rapidly to rain and snowmelt because of the more rugged topography. Despite a basin area more than two times greater than Fever Brook, discharge peaks (normalized to basin area) associated with most storms were greater at Swift River. The initial hydrograph recession was more rapid at Swift River, but then stabilized to sustain considerably higher base-flow levels, whereas flow at Fever Brook continued to recede. Estimates of base-flow discharge during the 21month study were 53 percent at Swift River compared to 42 percent at Fever Brook. Total runoff was 48 percent at Swift River compared to 41 percent at Fever Brook. Thus, despite a rapid hydrologic response, there is an important ground-water component to streamflow at Swift River. The lower percentage of runoff at Fever Brook was caused in part by evaporation from the extensive wetland areas in that basin. The surface storage reservoir appeared to have a greater effect on the ground-water storage reservoir in the hydrologic response at Fever Brook.

At Swift River, base cations were inversely correlated with discharge. Similar patterns of concentration variations of base cations and silica suggested that base cations primarily were derived from mineral weathering; concentrations diluted moderately at high flows and increased in summer when ground-water discharge dominated flow. At Fever Brook, base-cation concentrations were somewhat more variable, and the dilution of silica was much greater during high flow in spring, possibly reflecting elevated silica concentrations from diatom blooms in the impoundments. The high percentage of wetland areas and the major effect of deicing salts on stream chemistry at Fever Brook caused poor correlations of solute concentrations and discharge. Whereas concentrations of most base cations peaked in late summer, potassium concentrations at each site peaked later in the autumn, in association with leaf fall. At Swift River, sulfate concentrations were relatively constant, whereas at Fever Brook, sulfate concentrations decreased in summer when sulfate reduction occurred. During summer and early autumn at each site, alkalinity increased from less than 50 to near $150 \mu \mathrm{eq} / \mathrm{L}$ 
as base-cation concentrations increased and sulfate concentrations remained relatively constant or decreased.

Differences in the relative amounts of base cations (after subtracting the contributions of road deicing salts) and silica in the two streams suggest differences in the important mineral weathering reactions. At Swift River, net fluxes exceeded those at Fever Brook by 58 percent for silica and 41 percent for base cations. The disproportionately greater export of silica and calcium and the higher calcium:magnesium ratio at Swift River suggest that plagioclase weathering is more important at Swift River, and hornblende weathering is more important at Fever Brook. The overall weathering rate appears to be greater at Swift River because of a higher proportion of ground-water discharge relative to Fever Brook, and also due to the presence in one subbasin of easily weathered gabbro bedrock composed of hornblende and calcium feldspar. This subbasin comprises only 11.2 percent of the total Swift River Basin area but contributes nearly 25 percent of the total base cations, 16 percent of the total silica, and 77 percent of the total alkalinity exported from the basin.

In contrast to the other solutes, hydrogen ion and aluminum tended to increase in concentration with increasing discharge, reflecting the mixing of runoff from the more acidic rain and snowmelt waters with base flow. Rapid runoff from steep slopes in the Swift River Basin limited the degree to which acid was neutralized, resulting in episodic increases of aluminum concentration in the stream. As the ground-water component of stream discharge increased, $\mathrm{pH}$ and alkalinity increased and aluminum concentration decreased. Although baseline concentrations of hydrogen ion, DOC, and aluminum were higher at Fever Brook than at Swift River because of organic acidity generated in the wetlands, episodic increases of hydrogen ion and aluminum were more frequent at Swift River. In both streams, aluminum increased from less than 100 to nearly $300 \mu \mathrm{g} / \mathrm{L}$ during some high-discharge events. Because of the high DOC at Fever Brook, aluminum is likely to be organically bound and thus nontoxic.

Deicing salt application had a major effect on water quality in Swift River and Fever Brook Basins. Deicing salts increased the total ionic output flux by 41 percent at Swift River and 120 percent at Fever Brook. At Fever Brook, sodium in deicing salt exchanged with calcium and magnesium in the soil. The combined effects of loading in the applied salt and ion exchange in the soil caused increases in the output fluxes by 33 percent for calcium and 24 percent for magnesium. This ion exchange effect could promote soil infertility and soil acidification through the accelerated leaching of calcium and magnesium from soils.

\section{REFERENCES CITED}

April, R., Newton, R., and Coles, L.T., 1986, Chemical weathering in two Adirondack watersheds: Past and present-day rates: Geological Society of America Bulletin, v. 97, p. 1232-1238.

Ashenden, D.D., 1973, Stratigraphy and structure, northern portion of the Pelham Dome, north-central Massachusetts: Amherst, University of Massachusetts, M.S. thesis, $132 \mathrm{p}$.

Batchelder, G.L., Yuretich, R.F., and Leonard, W.C., 1983, Hydrogeochemical cycling in a watershed-groundwater system: Fort River and Cadwell Creek, Massachusetts: Amherst, University of Massachusetts, Water Resources Research Center, Publication No. 145, 80 p.

Bent, G.C., 1994, Effects of timber cutting on runoff to Quabbin Reservoir, central Massachusetts, in Effects of Human-Induced Changes on Hydrologic Systems: American Water Resources Association, Jackson Hole, Wyoming, June 1994, Proceedings, p. 187-196.

Bigelow, D.S., 1982, National Atmospheric Deposition Program instruction manual, site operation: Program Coordinator's Office, National Atmospheric Deposition Program, Colorado State University, Fort Collins, Colo., $30 \mathrm{p}$.

Brezonik, P.L., Edgerton, E.S., and Hendry, C.D., 1980, Acid precipitation and sulfate deposition in Florida: Science, v. 208, p. 1027-1029.

Bricker, O.P., Godfrey, A.E., and Cleaves, E.T., 1968, Mineral-water interaction during the chemical weathering of silicates: American Chemical Society Advances in Chemistry Series 73, p. 128-142.

Burns, D.A., 1989, Speciation and equilibrium relations of soluble aluminum in a headwater stream at base flow and during rain events: Water Resources Research, v. 25, p. 1653-1665.

Cherkauer, D.S., 1977, Effects of urban lakes on surface runoff and water quality: Water Resources Bulletin, v. 13, p. $1057-1067$. 
Clayton, J.L., 1988, Some observations on the stoichiometry of feldspar hydrolysis in granitic soil: Journal of Environmental Quality, v. 17, p. 153-157.

Cronan, C.S., 1978, Solution chemistry of a New Hampshire subalpine ecosystem: Biogeochemical patterns and processes: Dartmouth College, Hanover, New Hampshire, Ph.D. thesis, 248 p.

Davis, S.N. and DeWiest, R.J.M., 1966, Hydrogeology: New York, John Wiley and Sons, Inc., $463 \mathrm{p}$.

Dillon, P.J., Jeffries, D.S., Scheider, W.A., and Yan, N.D., 1980, Some aspects of acidification in southern Ontario, in Drablos, D., and Tollan, A., eds., Ecological impact of acid precipitation: International Conference, Sandefjord, Norway, 1980, Proceedings: Oslo, Norway, SNSF Project, p. 212- 213.

DiNardo, B., 1984, Rain of death: Worcester Magazine, September 12, 1984, p. 11-17.

Dolan, D.M., Yui, A.K., and Geist, R.D., 1981, Evaluation of river load estimation methods for total phosphorus: Journal of Great Lakes Research, v. 7, p. 207-214.

Drever, J.I., 1988, The geochemistry of natural waters: Englewood Cliffs, New Jersey, Prentice-Hall, 437 p.

Driscoll, C.T., 1985, Aluminum in acidic surface waters: chemistry, transport, and effects: Environmental Health Perspectives, v. 63, p. 93-104.

Driscoll, C.T., Baker, J.P., Bisogni, J.J., Jr., and Schofield, C.L., 1980, Effect of aluminum speciation on fish in dilute acidified waters: Nature, v. 284, p. 161-164.

Driscoll, C.T., Likens, G.E., Hedin, L.O., Eaton, J.S., Bormann, F.H., 1989, Changes in the chemistry of surface waters: Environmental Science and Technology, v. 23, p. 137-143.

Eschman, D.F., 1966, Surficial geology of the Athol quadrangle, Worcester and Franklin Counties, Massachusetts: U.S. Geological Survey Bulletin 1163-C, 20 p.

Eshleman, K.N., and Hemond, H.F., 1985, The role of organic acids in the acid-base status of surface waters at Bickford watershed, Massachusetts: Water Resources Research, v. 21, p. 1503-1510.

Fishman, M.J., and Friedman, L.C., 1989, Methods for determination of inorganic substances in water and fluvial sediments: U.S. Geological Survey Techniques of Water-Resources Investigations, book 5, chap. A1, $545 \mathrm{p}$.
Gadoury, R.A., Girouard, G.G., and Letty, D.F., 1984, Water resources data-Massachusetts and Rhode Island, water year 1982: U.S. Geological Survey Water-Data Report MA-RI-82-1, $237 \mathrm{p}$.

Gadoury, R.A., Girouard, G.G., and Ries, K.G., III, 1985 , Water resources data, Massachusetts and Rhode Island, water year 1983: U.S. Geological Survey Water-Data Report MA-RI-83-1, 237 p.

Gadoury, R.A., Socolow, R.S., Kent, D.J., and Russell, J.P., 1989, Water resources data, Massachusetts and Rhode Island, water year 1987: U.S. Geological Survey WaterData Report MA-RI-87-1, 243 p.

Galloway, J.N., Schofield, C.L., Peters, N.E., Hendry, G.R., and Altwicker, E.R., 1983, Effects of atmospheric sulfur on the composition of three Adirondack lakes. Canadian Journal of Fisheries and Aquatic Sciences, v. 40, p. $799-806$.

Gambell, A.W., and Fisher, D.W., 1966, Chemical composition of rainfall, eastern North Carolina and southeastern Virginia: U.S. Geological Survey Water-Supply Paper 1535-K, $41 \mathrm{p}$.

Garrels, R.M., and Christ, C.L., 1965, Solutions, minerals, and equilibria: San Francisco, Freeman, Cooper, and Company, $450 \mathrm{p}$.

Gay, F.B., and Melching, C.S., 1995, Relation of precipitation quality to storm type and deposition of dissolved chemical constituents from precipitation in Massachusetts, 1983-85: U.S. Geological Survey Water-Resources Investigations Report 94-4224.

Gelbspan, R., 1984, Acid rain study says Massachusetts waters harmed: Boston Globe, May 29, 1984, p. 48.

Gorham, E., 1976, Acid precipitation and its influence upon aquatic ecosystems: an overview: Water, Air, and Soil Pollution, v. 6, p. 457-481.

Halliwell, D.B., 1985, Our impacted resources, more than just a few dead fish: Massachusetts Wildlife, v. 36, MayJune 1985 , p. 10-15.

Hem, J.D., 1985, Study and interpretation of the chemical characteristics of natural water (3d ed.): U.S. Geological Survey Water-Supply Paper 2254, 263 p.

Hemond, H.F., and Eshleman, K.N., 1984, Neutralization of acid deposition by nitrate retention, Bickford watershed, Massachusetts: Water Resources Research, v. 20, p. 1718-1724. 
Henriksen, A., 1980, Acidification of freshwaters-a large scale titration, in Drablos, D. and Tollan, A., eds., Ecological effects of acid precipitation: Johs. Grefslie Trykkeri A/S, Mysen, Norway, p. 68-74.

Henriksen, A., Skogheim, O.K., and Rosseland, B.O., 1984, Episodic changes in $\mathrm{pH}$ and aluminum speciation kill fish in a Norwegian salmon river: Vatten, v. 40, p. $255-260$.

Hooper, R.P., Christophersen, N., and Peters, N.E., 1990, Modelling stream water chemistry as a mixture of soil water end members-An application to the Panola Mountain Watershed, Georgia, USA: Journal of Hydrology, v. 116, p. 3211-3243.

Huling, E.E., and Hollocher, T.C., 1972, Groundwater contamination by road salt: steady-state concentrations in east-central Massachusetts: Science, v. 176, p. 288-290.

Huntington, T.G., Hooper, R.P., and Aulenbach, B.T., 1994, Hydrologic processes controlling sulfate mobility in a small forested watershed: Water Resources Research, v. 30 , p. $283-295$.

Johnson, N.M., 1979, Acid rain: neutralization within the Hubbard Brook ecosystem and regional implications: Science, v. 204, p. 497-499.

Johnson, N.M., Likens, G.E., Bormann, F.H., Fisher, D.W., and Pierce, R.S., 1969, A working model for the variation in stream water chemistry at the Hubbard Brook Experimental Forest, New Hampshire: Water Resources Research, v. 5, p. 1353- 1363.

Jones, B.F., Kennedy, V.C., and Zellweger, G.W., 1974, Comparison of observed and calculated concentrations of dissolved aluminum and iron in stream water: Water Resources Research, v. 10, p. 791-793.

Katz, B.G., Bricker, O.P., and Kennedy, M.M., 1985, Geochemical mass-balance relationships for selected ions in precipitation and stream water, Catoctin Mountains, Maryland: American Journal of Science, v. 285, p. 931-962.

Kerr, R.A., 1981, There is more to "acid rain" than rain: Science, v. 211, p. 692-693.

Knapp, E., 1990, Weathering processes and acid neutralization: A study of two small watersheds in Central Massachusetts: Amherst, University of Massachusetts, M.S. thesis.

Kunkle, S.H., 1972, Effects of road salt on a Vermont stream: Journal of the American Water Works Association, v. 64, p. 290-295.
Leonard, W.C., Yuretich, R.F., and Pohanka, S.J., 1984, Hydrogeology and processes of acid neutralization in Cadwell Creek watershed, Quabbin Reservoir, Massachusetts: Amherst, University of Massachusetts, Water Resources Research Center Publication No. 148, 122 p.

Likens, G.E., Bormann, F.H., Pierce, R.S., Eaton, J.S., and Johnson, N.M., 1977, Biogeochemistry of a forested ecosystem: New York, Springer-Verlag, $146 \mathrm{p}$.

Likens, G.E., Wright, R.F., Galloway, J.N., and Butler, T.J., 1979, Acid rain: Scientific American, v. 241, p. 43-51.

Lindberg, S.E., and Garten, Jr., C.T., 1988, Sources of sulphur in forest canopy throughfall: Nature, v. 336, p. 148- 151.

Lyford, W.H., 1964a, Coarse fragments in the Gloucester soils of the Harvard Forest: Petersham, Massachusetts, Harvard University, Harvard Forest Paper No. 9, 16 p.

1964b, Water-table fluctuations in periodically wet soils of central New England: Petersham, Massachusetts, Harvard University, Harvard Forest Paper No. 8, $15 \mathrm{p}$.

Makower, J., 1964, Geology of the Prescott intrusive complex, Quabbin Reservoir quadrangle, Massachusetts: Amherst, University of Massachusetts, M.S. thesis, $91 \mathrm{p}$.

McAvoy, D.C., 1989, Episodic response of aluminum chemistry in an acid-sensitive Massachusetts catchment: Water Resources Research, v. 25, p. 233-240.

McManamon, A., 1990, Hydrologic response of a small watershed in central Massachusetts to storm events and seasonal changes: Amherst, University of Massachusetts, M.S. thesis.

Michener, S.R., 1983, Bedrock geology of the PelhamShutesbury syncline, Pelham Dome, west-central Massachusetts: Amherst, University of Massachusetts, M.S. thesis, $101 \mathrm{p}$.

Monahan, S.E., 1984, Environmental chemistry (4th ed.): Boston, Willard Grant Press, 612 p.

Mulholland, J.W., 1974, Surficial geology of the Ware quadrangle, Worcester and Hampshire Counties, Massachusetts: Amherst, University of Massachusetts, Ph.D. thesis, $227 \mathrm{p}$.

Munger, J.W., and Eisenreich, S.J., 1982, Continental-scale variations in precipitation chemistry: Environmental Science and Technology, v. 17, p. 32A-41A. 
National Acid Precipitation Assessment Program, 1983, Annual report, 1983, to the President and Congress: Interagency Task Force on Acid Precipitation, Washington, D.C., 73 p.

National Oceanic and Atmospheric Administration, 1983, Climatological data, New England: National Oceanic and Atmospheric Agency, v. 95, no. 12, 38 p.

1984, Climatological data, New England: National Oceanic and Atmospheric Administration, v. 96 , no. 1-12.

1985a, Climatological data annual summary New England, 1985: National Oceanic and Atmospheric Administration, v. 97, 36 p.

1985b, Climatological data, New England: National Oceanic and Atmospheric Administration, v. 97, no. 1-8.

Nesson, F.L., 1983, Great waters, a history of Boston's water supply: Hanover, New Hampshire, University Press of New England, $106 \mathrm{p}$.

Newton, R.M., 1978, Stratigraphy and structure of some New England tills: Amherst, University of Massachusetts, Ph.D. thesis, 241 p.

Oberts, G.L., 1986, Pollutants associated with sand and salt applied to roads in Minnesota: Water Resources Bulletin, v. 22, p. 479-483.

Pack, D.H., 1980, Precipitation chemistry patterns: a twonetwork data set: Science, v. 208, p. 1143-1145.

Parnell, R.A., Jr., 1983, Weathering processes and Pickeringite formation in a sulfidic schist: a consideration in acid precipitation neutralization studies: Environmental Geology, v. 4, p. 209-215.

Patric, J.H., and Lyford, W.H., 1980, Soil-water relations at the headwaters of a forest stream in central New England: Petersham, Massachusetts, Harvard University, Harvard Forest Paper No. 22, 24 p.

Peters, N.E., 1989a, Atmospheric deposition of sulfur to a granite outcrop in the piedmont of Georgia, U.S.A., in, J.W. Delleur, ed., International Association of Hydrologic Sciences Publication No. 179, p. 173-181.

Peters, N.E., 1989b, Contributions of cation exchange and mineral weathering to cation transport at Panola Mountain, Georgia [abs.]: Chapman Conference (American Geophysical Union) Proceedings, Bar Harbor, Maine.

Peters, N.E., Schroeder, R.A., and Troutman, D.E., 1982, Temporal trends in the acidity of precipitation and surface waters of New York: U.S. Geological Survey Water-Supply Paper 2188, $35 \mathrm{p}$.
Plummer, L.N., Jones, B.F., and Truesdell, A.H., 1976, WATEQF - A FORTRAN IV version of WATEQ, a computer program for calculating chemical equilibrium of natural waters: U.S. Geological Survey WaterResources Investigations Report 76-13, 63 p.

Raynor, G.S., and Hayes, J.V., 1982, Concentrations of some ionic species in central Long Island, New York, Precipitation in relation to meteorological variables: Water, Air, and Soil Pollution, v. 17, p. 309-335.

Retelle, M.J., 1979, Surficial geology of the southern half of the Bernardston quadrangle, Massachusetts-Vermont: Amherst, University of Massachusetts, M.S. thesis, $98 \mathrm{p}$.

Reuss, J.O., and Johnson, D.W., 1986, Acid deposition and the acidification of soils and waters: Ecological Studies, Springer-Verlag, N.Y., v. 59, 199 p.

Risley, J.C., and Shanley, J.B., 1994, Effects of storm paths on precipitation chemistry, and variations of withinstorm chemistry during selected storms in central Massachusetts, 1986-87: U.S. Geological Survey WaterResources Investigations Report 94-4084, 34 p.

Rittmaster, R.L. and Girouard, G.G., 1992, Water quality and hydrologic data of the West Branch Swift River and East Branch Fever Brook, Quabbin Reservoir drainage basin, Massachusetts: U.S. Geological Survey Open-File Report 90-182, 73 p.

Robinson, P., 1967, Geology of the Quabbin Reservoir area, central Massachusetts, in, New England Intercollegiate Geology Conference, 59th annual meeting, guidebook: Amherst, Massachusetts, p. 114-127.

Samson, P.J., 1987, Estimating the atmospheric input of pollutants into a watershed: Water, Air, and Soil Pollution, v. 35, p. $7-17$.

Scharpf, R.F., and Srago, M., 1974, Conifer damage and death associated with the use of highway deicing salt in the Lake Tahoe basin of California and Nevada, in, Proceedings: Lake Tahoe Research Seminar II, 27 September 1974, Sands Vagabond Convention Center, South Lake Tahoe, California, Report No. NSF/RA/G-74-012, p. 36-61.

Schindler, D.W., 1988, Effects of acid rain on freshwater ecosystems: Science, v. 239, p. 149-157.

Schofield, C.L., and Trojnar, J.R., 1980, Aluminum toxicity to brook trout (Salvelinus fontinalis) in acidified waters, in Toribara, T.Y., and others, eds., Polluted Rain: Plenum Press, New York, 514 p. 
Shaffer, P.W., and Galloway, J.N., 1982, Acid precipitation: the impact on two headwater streams in Shenandoah National Park, Virginia, in Herrmann, R., and Johnson, A.I., eds., International Symposium of Hydrometeorology: American Water Resources Association, p. 43-53.

Shanley, J.B., 1989, Factors controlling sulfate retention and transport in a forested watershed in the Georgia piedmont: Laramie, University of Wyoming, Ph.D. thesis, $97 \mathrm{p}$.

Shanley, J.B., 1994, Effects of ion exchange on stream solute fluxes in a basin receiving highway deicing salts: Journal of Environmental Quality, v. 23, p. 977-986.

Shearer, C.K., 1983, Petrography, mineral chemistry, and geochemistry of the Hardwick tonalite and associated igneous rocks, central Massachusetts: Amherst, University of Massachusetts, Ph.D. thesis, 265 p.

Smith, R.A., and Alexander, R.B., 1983, Evidence for acidprecipitation-induced trends in stream chemistry at hydrologic bench-mark station: U.S. Geological Survey Circular 910, 12 p.

Steckl, P., 1985, A hydrogeologic investigation of two small watersheds of the eastern Quabbin basin: Amherst, University of Massachusetts, M.S. thesis, $169 \mathrm{p}$.

Stone, J.R., London, E.H., and Langer, W.H., 1979, Map showing textures of unconsolidated materials, Connecticut Valley urban area, central New England: U.S. Geological Miscellaneous Investigations Map I-1074-B (scale 1:125,000).

Suarez, E.L., and Jones, U.S., 1982, Atmospheric sulfur as related to acid precipitation and soil fertility: Soil Science Society of America Journal, v. 46, p. 976-980.

Sung, W., Gallot, W.J., Gottlieb, R., and Viscardi, D.A., 1984, Aluminum in drinking waters: Journal of the New England Water Works Association, v. 98, p. 363-377.

Thornbury, W.D., 1969, Principles of geomorphology ( $2 \mathrm{~d}$ ed.): New York, John Wiley and Sons, 594 p.
Ulrich, B., 1983, An ecosystem oriented hypothesis on the effect of air pollution on forest ecosystems, in, Ecological Effects of Acid Deposition: National Swedish Environmental Protection Board - Report PM 1636, p. 221-231.

U.S. Department of Agriculture, 1975, Soil taxonomy: a basic system of soil classification for making and interpreting soil surveys: Soil Conservation Service Handbook 436, 754 p.

U.S. Environmental Protection Agency, 1986, Quality criteria for water: Office of Water Regulations and Standards, EPA-440/5-86-001, 296 p.

Velbel, M.A., 1985, Geochemical mass balances and weathering rates in forested watersheds of the southern Blue Ridge: American Journal of Science, v. 285, p. 904-930.

Wiklander, L., 1975, The role of neutral salts in the ion exchange between acid precipitation and soil: Geoderma, v. 14, p. 93-105.

Wilcox, D.A., 1986, The effects of deicing salts on water chemistry on Pinhook Bog, Indiana: Water Resources Bulletin, v. 22, p. 57-65.

Wright, R.F., Norton, S.A., Brakke, D.F., and Frogner, T., 1988, Experimental verification of episodic acidification of freshwaters by sea salts: Nature, v. 334, p. 422-424.

Yuretich, R.F., and Batchelder, G.L., 1988, Hydrogeochemical cycling and chemical denudation in the Fort River watershed, central Massachusetts: an appraisal of massbalance studies: Water Resources Research, v. 24, p. $105-114$.

Yuretich, R.F., Leonard, W., and Pohanka, S.J., 1989, Hydrogeologic factors affecting acid neutralization in Cadwell Creek watershed, central Massachusetts: Water Resources Research, v. 25, p. 644-654.

Yuretich, R.F., Stekl, P.J., and Pohanka, S.J., 1986, Hydrogeology and mineral weathering reactions in watersheds of central Massachusetts: Amherst, University of Massachusetts, Water Resources Research Center Publication No. 152, 85 p. 